\author{
Universidade de São Paulo \\ Faculdade de Filosofia, Letras e Ciências Humanas \\ Departamento de Letras Modernas \\ Programa de Pós- Graduação em Língua Espanhola e Literaturas \\ Espanhola e Hispano-Americana
}

Fernanda da Silva Pereira

O DRAMA BUFO-TRÁGIGO DO CALAVERA

Uma leitura de El Ideal de Un Calavera

São Paulo

2011 


\author{
Universidade de São Paulo \\ Faculdade de Filosofia, Letras e Ciências Humanas \\ Departamento de Letras Modernas \\ Programa de Pós- Graduação em Língua Espanhola e Literaturas \\ Espanhola e Hispano-Americana
}

\title{
O DRAMA BUFO-TRÁGIGO DO CALAVERA \\ Uma leitura de El Ideal de Un Calavera
}

Fernanda da Silva Pereira

Dissertação apresentada ao Programa de PósGraduação em Língua Espanhola e Literaturas Espanhola e Hispano-Americana da Faculdade de Filosofia, Letras e Ciências Humanas da Universidade de São Paulo para obtenção do titulo de Mestre em Letras

Orientadora: Profa. Dra. Laura Janina Hosiasson

São Paulo

2011 
Autorizo a reprodução e divulgação total ou parcial deste trabalho, por qualquer meio convencional ou eletrônico, para fins de estudo e pesquisa, desde que citada a fonte.

Catalogação na Publicação

Serviço de Biblioteca e Documentação

Faculdade de Filosofia, Letras e Ciências Humanas da Universidade de São Paulo

Pereira, Fernanda da Silva

O drama bufo-trágico do Calavera : uma leitura de El Ideal de un Calavera / Fernanda da Silva Pereira ;

orientadora Laura Janina Hosiasson. - São Paulo, 2011.

$100 \mathrm{p}$.

Dissertação (Mestrado) - Faculdade de Filosofia, Letras e Ciências Humanas da Universidade de São Paulo. Departamento de Letras Modernas. Área de concentração: Língua Espanhola e Literaturas Espanhola e Hispano-Americana.

1. Literatura chilena - Século XIX. 2. Romance hispano-americano. 3. Intertextualidade. 4. Epistolografia. 5. Blest Gama, Alberto, 1830-1920. I. Título. II. Hosiasson, Laura Janina. 
FOLHA DE APROVAÇÃO

Fernanda da Silva Pereira

O drama bufo-trágico do calavera - Uma leitura de El ideal de un Calavera

Dissertação apresentada à Faculdade de Filosofia, Letras e Ciências Humanas da

Universidade de São Paulo para obtenção do título de Mestre em Letras

\section{Banca Examinadora}

Prof. Dr.

Instituição:

Assinatura:

Prof. Dr.

Instituição:

Assinatura:

Prof. Dr.

Instituição:

Assinatura: 
A Ernane e Marilena, meus pais. 


\section{AGRADECIMENTOS}

Os meus mais sinceros agradecimentos à Professora Dra. Laura Janina Hosiasson, que com muita dedicação acompanhou-me e orientou-me, no sentido mais fiel desta palavra, desde o início de meus estudos em nível de Iniciação Científica. Durante estes quase seis anos foram inúmeras as reuniões, indicações, e-mails, correções, revisões, enfim, tudo que cotidianamente envolve uma excelente orientação.

A professora Susana Zanetti que me recebeu tão atenciosamente em Buenos Aires e cedeu-me valiosos materiais de estudos, entre eles uma cópia da terceira edição de Ideal de un Calavera. Agradeço também o grande auxílio das Professoras Dra. Salete de Almeida Cara e Dra. Adriana Kanzepolsky, membros da Banca de Qualificação que, com grande interesse e muita generosidade, dispuseram-se a comentar, criticar e questionar a pesquisa.

A todos os professores do Programa de Língua e Literaturas Espanhola e Hispanoamericana, em especial, registro meus agradecimentos àqueles que foram meus professores na graduação. Aos colegas e amigos do Grupo de Estudos: Ana, Jader, Olga, Márcio, Luana, Tatiane, Fátima, Néia e Lilian.

Agradeço o financiamento à pesquisa, fornecida pela CAPES e, do mesmo modo, ao Programa Centros Associados Brasil /Argentina Convênio Unicamp, USP e UBA. A Edite, por todo o seu auxílio com os regulamentos burocráticos. A Alberto e Luciano, funcionários da biblioteca da Universidade de Buenos Aires.

À família, por toda a paciência e compreensão, por minha ausência e mais de mil quilômetros de distância. Aos amigos que não resisto ao desejo de nomeá-los: Patrícia, Nina, Pietra, Rosane, Tathiana, Paulinha, Alice, Aline, Jaqueline, Elza, Circe, Luciane, Ana e Cristiano, Bianca, Birigui, Monica, Alessandra, Tatiane, Micheli, Gustavo, Alessandra, Thales, Renie, Robson, Candy, Marcos Maurício, Elena, Luciana, Bruna, Lisi, Adriana, Maira, Eleni e Karina. Espero não ter esquecido ninguém. 
Transforma-se o amador na cousa amada Por virtude do muito imaginar

Não tenho, logo, mais que desejar Pois em mim tenho a parte desejada

Se nela este minha alma transformada Que mais deseja o corpo de alcançar? Em si somente pode descansar Pois consigo tal alma está ligada

Mas esta linda e pura semideia Que, como um acidente em seu sujeito Assim como a alma minha conforma

Está no pensamento como ideia [e] o vivo e puro amor de que sou feito Com a matéria simples busca a forma 
Resumo

Este trabalho empreende uma leitura da obra El ideal de un Caravela (1863) do escritor chileno Alberto Blest Gana (1830-1920), tendo como objetivo investigar as construções ambíguas que permeiam a narrativa e apontam uma perspectiva trágico-cômica. Sendo assim, nosso ponto de partida é a explícita intertextualidade do romance com a Correspondência de Abelardo e Heloísa. Leitor das cartas de seu famoso homônimo, o protagonista Abelardo Manríquez identifica-se e espelha-se diretamente com a história dos amantes do século XII e através dela passa a romantizar sua própria busca amorosa. Contudo, tal busca carrega em seu bojo complicações que estão além da mera idealização amorosa, ao invés de amor encontramos a ideia fixa que o levará a entregar-se a morte.

Avesso às convenções sociais, o jovem calavera, segue na contramão da sociedade chilena oitocentista, num movimento similar ao que ocorre com a personagem de Cervantes, idealiza um sonho extemporâneo ao seu tempo e ao próprio estilo da narrativa. De modo que dentro do contexto social chileno representado no romance, os sentimentos do jovem são satirizados pelo mesmo narrador por sua inadequação com os hábitos e costumes sociais da época.

O desejo da personagem perturba a ordem social da convenção e por essa incompatibilidade o herói é ridicularizado e condenado desde o início do livro. Com efeito, a composição de sua personalidade advém de um intrincado jogo, cujo sentido irônico ergue-se por conta do encaminhamento da temática romântica para uma narrativa que se pretende realista. Nesse caminhar, a reflexão desenvolvida permite indicar as contradições e incoerências da sociedade chilena do início do século XIX, ao apresentar problematicamente o drama bufo-trágico do jovem anti-herói Abelardo Manríquez.

Palavras Chaves: Literatura Chilena, Alberto Blest Gana, Intertextualidade 


\begin{abstract}
This investigation proposes to read Chilean writer Alberto Blest Gana's novel El ideal de un calavera (1863), trying to detect the narrative ambiguous constructions that point towards a tragic-comic perspective. Our point of departure is the romance's explicit intertextuality with Letters from Abelard \& Heloise. Abelardo Manríquez, Blest Gana's protagonist, is an obsessive reader of his famous homonymous's letters and aims to emulate the romantic story of the twelve century's lovers throughout his own romantic search. However, this search carries in its center complications that surpass de mere amorous idealization: instead of love, we find a fixed idea that will lead him to death.

Denying social conventions, the young 'calavera' goes on trough the opposite side of nineteen century Chilean Society's path. His peculiar way reminds Cervantes's hero, idealizing a dream in complete anachronism with his historical time and with the narrative style, as well. Within the Chilean context represented in the novel, the young protagonist's feelings are satirized by the narrator for its unsuitable habits and ways.

The protagonist's desires disturb the conventional social order and because of this incompatibility, he will be condemned from the beginning of the book. In fact, the composition of his personality comes out of an intricate game that implies an ironic sense emerging from a romantic theme towards a narrative that pretends to be realistic. Along this path, it becomes possible to follow certain contradictions and incoherencies of Chilean Society from the first half of nineteenth's century, presented in a problematic way, through the form of Manríquez young anti-hero’s bufo-tragic drama.
\end{abstract}




\section{Sumário}

INTRODUÇÃ

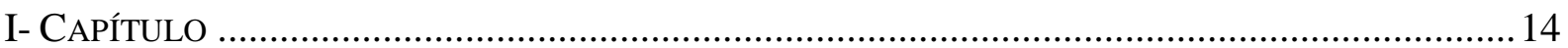

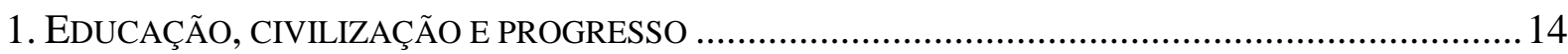

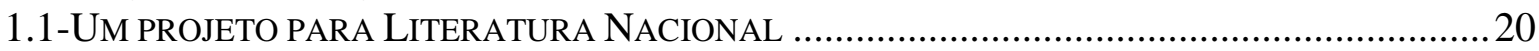

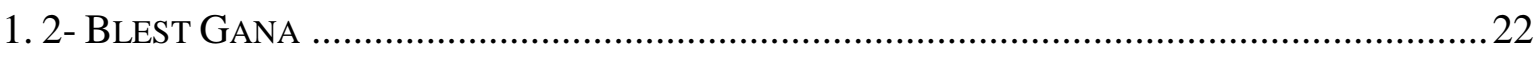

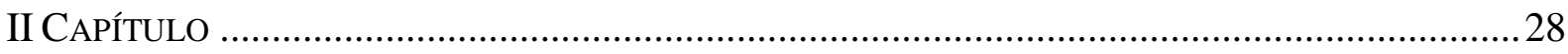

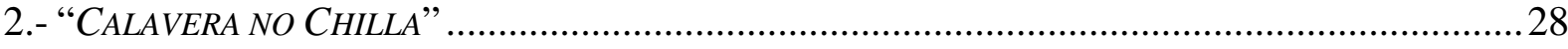



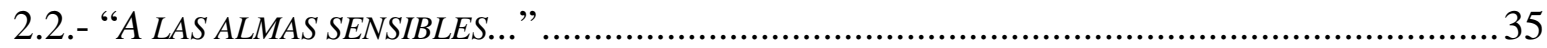

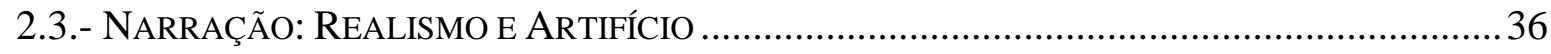

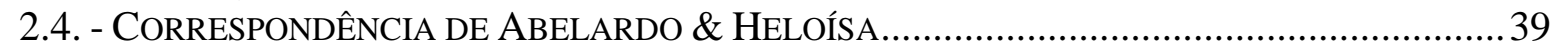

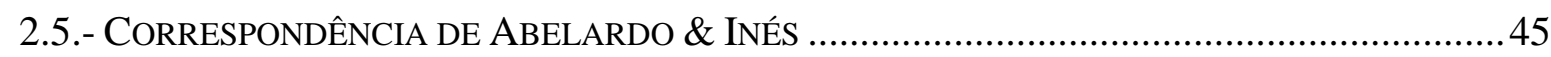

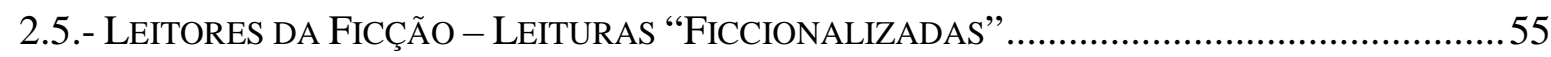

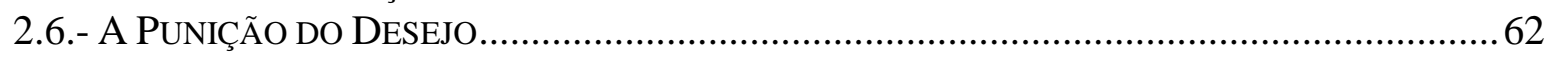

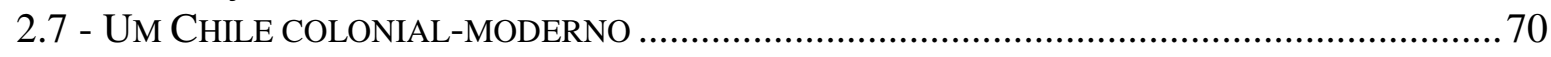

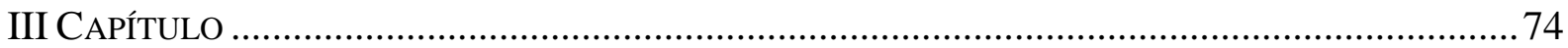

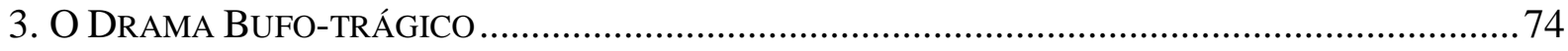

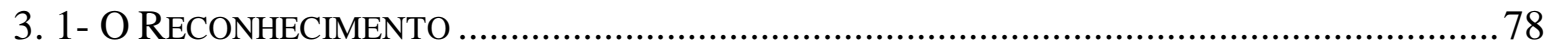

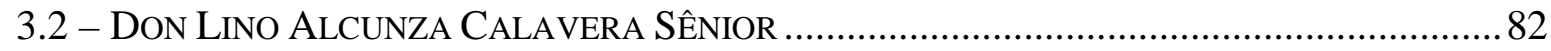

3.3- CALAVERA - TIMOLÉON MIRAFLORES, O HOMEM DOS QUINZE RAPTORES DE

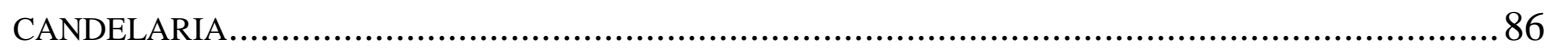

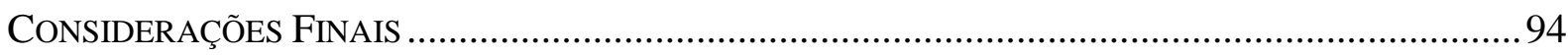

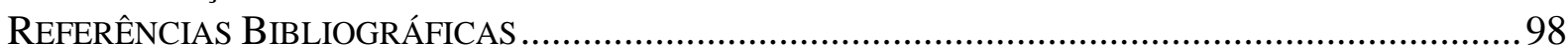




\section{INTRODUÇÃO}

Como o próprio subtítulo indica, a proposta desta dissertação é a de realizar uma leitura do romance El ideal de un Calavera, publicado em 1863, pelo escritor chileno Alberto Blest Gana. Divido originalmente em dois tomos, o livro nos conta, ao longo de quase 700 páginas, a trajetória de vida de Abelardo Manríquez, protagonista do romance, cujo fim se desenrola de forma trágica.

Em princípio, a ideia era focar nossa análise na explícita relação intertextual da obra de Blest Gana com a Correspondência de Abelardo e Heloísa, percorrendo por esta empreitada a composição da personagem Abelardo Manríquez, em contraposição paródica com a histórica imagem de seu famoso homônimo do século XII, Pierre Abelardo. Contudo, no decorrer do trabalho de pesquisa, este foco foi se ampliando e seguimos a chave inicial, conjugando-a a outros elementos da trama, que não só colaboraram para desenvolvê-la, como também ajudaram a torná-la mais coerente.

Nesse sentido, estruturamos nossa leitura baseada em dois elementos que consideramos os principais eixos da obra. De um lado, observamos a relação do romance com a grande tradição da literatura, representada a partir da intertextualidade 
da narrativa com a Correspondência de Abelardo e Heloísa, e de outro, examinamos a caracterização dos costumes e hábitos locais, argumentos estes fundamentais para o projeto de literatura nacional com o qual o autor do romance está comprometido. Por estas vias, deparamo-nos com a complexidade do drama bufo-trágico de Abelardo Manríquez, cujas implicações demonstraremos ao logo de todo o trabalho.

El ideal de un calavera possui quatro partes, Escenas del Campo; Los Calaveras; El ideal e Conclusión, sobre as quais tentaremos nos debruçar de maneira mais ou menos organizada. Por vezes, foi necessário cumprir um movimento de avanços e recuos na ação narrativa, para garantir o andamento da proposta de análise. Em razão da extensão e variedade de situações, realizamos alguns recortes de leitura, deixando de lado cenas e personagens que mereceriam maior destaque.

A presente dissertação está estruturada em três capítulos os quais, por sua vez, apresentam-se subdivididos em tópicos. No primeiro capítulo "Educação, Civilização e Progresso”, apresentamos a contextualização do cenário político-social chileno da primeira metade do século XIX, período marcado pelo desejo de promoção da leitura no país. Concisa e sem pretensões históricas, esta parte do trabalho corresponde também à sistematização de fatos e acontecimentos que possibilitaram as transformações culturais e artísticas propiciando a formação e fortalecimento da literatura denominada chilena.

Nessa panorâmica, arriscamos problematizar as motivações e os fins da literatura como expressão nacional, tomando como apoio teórico os trabalhos de Antonio Candido ${ }^{1}$, Beatriz González Stephan ${ }^{2}$ e Leyla Perrone-Moisés ${ }^{3}$, buscando neles subsídios para compreender o ambíguo processo de fundação de uma literatura nacional, associando-a a sua instrumentalização como modelo de progresso liberal latino-americano no século XIX.

O segundo capítulo, “Calavera no Chilla”, que também não foge dos enlaces históricos, está dedicado a iluminar questões relativas à construção da imagem da literatura nacional chilena, manipulada pelo autor do romance e, de igual modo, pretende investigar o método como ele utilizou o recurso da intertextualidade com Correspondência de Abelardo e Heloísa, no desenvolvimento da trama.

\footnotetext{
${ }^{1}$ CANDIDO. Antonio. Formação da Literatura Brasileira. São Paulo: Editora Ouro sobre Azul, 2004.

${ }^{2}$ GONZALEZ STEPHAN, Beatriz. La historiografía literaria del liberalismo hispanoamericano del siglo XIX. Habana: Casa de las Américas.1987.

${ }^{3}$ PERRONE-MOISÉS. Leyla. "Paradoxos do nacionalismo na América Latina". In: Vira e Mexe Nacionalismo - Paradoxos do Nacionalismo Literário. São Paulo: Cia das Letras. 2007.
} 
Leitor extensivo dessas cartas, o protagonista Abelardo Manríquez, é um leitor que tem a sua imaginação invadida pela leitura, assemelhando-se assim à romântica maneira de Emma Bovary de [...] estabelecer [na leitura] o elemento mediador entre ela

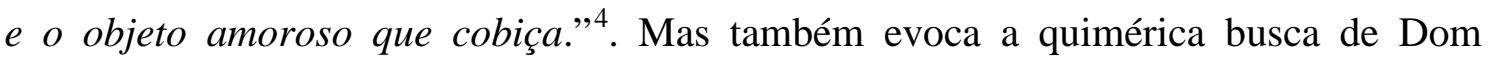
Quixote, que idealiza um sonho extemporâneo não só ao seu tempo bem como ao próprio estilo da narrativa.

Como nos dois célebres casos literários, a personagem de Blest Gana envolvese em suas repetidas leituras da Correspondência e se espelha na sua peculiar interpretação da história de amor do século XII para tomá-la como modelo para sua própria vida. Em consonância com a idealização de Abelardo Manríquez, também apresentamos as incorporações românticas e re-significações simbólicas que a leitura da Correspondência de Abelardo e Heloísa sofreu no decorrer dos séculos, dialogando, desta maneira, com a tradição literária.

Numa busca anacrônica, Abelardo Manríquez espera de sua amada, Inés Arboleda, típica coquete do século XIX, o mesmo amor e servidão da Heloísa do século XII. Mas, enfrentado a uma realidade completamente distinta à dos amantes medievais, o seu desejo torna-se um ideal ilusório que provoca o desajuste paródico com a sociedade oitocentista representada no romance. Deste modo, as referências às missivas não só permeiam a narrativa, mas também se articulam fluidamente com os quadros de costumes que se apresentam ao longo do romance.

Finalmente, no terceiro capítulo, “O drama bufo-trágico”, descrevemos os dispositivos formais que compreendem a construção da obra. Privilegiando a observação do diálogo entre a ambiguidade do conteúdo, com as variedades da forma, indicando deste modo a conformidade da matéria ambígua ao hibridismo dos gêneros.

O jogo entre o trágico e cômico é aqui subordinado ao gênero de costumes, no qual o autor parece manter o foco principal. Através dos recursos e efeitos utilizados por ele, para provocar a comoção e o riso no leitor, tentaremos demonstrar as alternâncias das chaves trágicas e cômicas. No que se refere à tragédia, recorremos principalmente aos preceitos da Poética de Aristóteles e para tratar sobre cômico, invocamos os conceitos de Henri Bergson, apontados em seu livro O Riso.

\footnotetext{
${ }^{4}$ SANTIAGO, Silviano. "Eça autor de Madame Bovary”. In: Uma literatura nos trópicos. São Paulo: Perspectiva, 1978. p. 64.
} 


\section{I- CAPÍTULO}

\section{EDUCAÇÃO, CIVILIZAÇÃo E PROGRESSO}

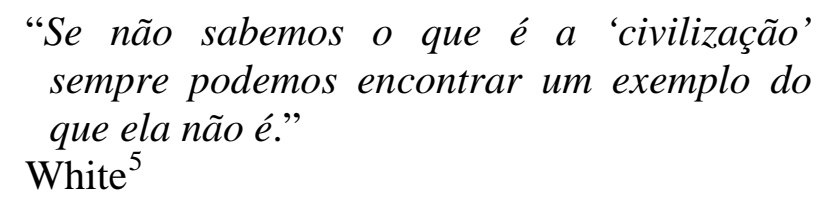

Segundo o historiador Fábio Wasseman ${ }^{6}$, o Chile foi o primeiro país da América hispânica a organizar-se nos setores político, burocrático e financeiro. Naturalmente, isso não significa que essa estruturação não tenha sido precedida e acompanhada por conflitos. A década de 1820, período logo após a independência, foi marcada por problemáticas disputas regionais e setoriais que dividiram os interesses e as orientações ideológicas das elites chilenas. Estes conflitos deram-se principalmente entre os chamados pipiolos e pelucones; os primeiros eram partidários dos conceitos liberais de nação, inspirados na Revolução Francesa e na Independência dos Estados Unidos da América, enquanto os segundos mantinham uma postura mais conservadora e cautelosa frente às mudanças.

As propostas iniciais dos liberais e dos conservadores sobre as estruturas que deveriam reger a nova República eram bastante divergentes, de tal forma que seus embates ideológicos acabavam por resultar em inúmeras substituições de governos e trocas de constituições. A constante disputa pelo poder só foi atenuada após a derrota dos liberais na Batalha de Lircay, em 1830. Liderado por Diego Portales, o renovado partido conservador elaborou a Constituição de 1833, sobre a qual se estabeleceu a

\footnotetext{
${ }^{5}$ WHITE, Hayden. “As formas do Estado Selvagem: a arqueologia de uma idéia.” In: Trópicos do discurso. São Paulo: Edusp, 1994. p.171.

${ }^{6}$ Fabio Wasserman é historiador pesquisador do Instituto de História Argentina e Americana "Dr. Emilio Ravignani” e docente de História argentina I, na Faculdade de Filosofia e Letras da Universidade de Buenos Aires. Especialista em pesquisas sobre análise e comparação das condições de produção e conteúdos das representações do passado elaboradas no Chile e no Rio da Prata entre os anos de 1830 e 1860.
} 
centralização e a concentração do poder no executivo nacional. Esse fato deu início a um longo período em que o Chile permaneceria sob o comando dos conservadores:

Así, y a diferencia de las convulsionadas repúblicas vecinas, Chile fue gobernado durante varias décadas por presidentes que ejercieron el mando durante dos períodos consecutivos de diez años cada uno: José J. Pietro (1831- 1841), Manuel Bulnes (1841-1851), Manuel Montt (1851-1861) José J. Pérez (1861-1871). Claro que esta sucesión no implicó la ausencia de conflictos por el acceso al poder y la orientación de las políticas públicas, sino que los mismos pudieron ser resueltos, incluso cuando se produjeron levantamientos o motines como los de 1851 y 1859. ${ }^{7}$

O extenso período do governo conservador garantiu estabilidade política e econômica ao país recém-independente. Entretanto, para a efetivação do processo de superação das estruturas coloniais, apenas a rearticulação desses aspectos não parecia suficiente. O desejo dos liberais de converter o Chile em um país moderno chocava-se com o pensamento conservador de prolongação da ordem colonial. Para muitos intelectuais liberais tornava-se imprescindível apagar os lastros desse passado que impregnavam os espaços públicos, os costumes e os hábitos da população. Por outras palavras, eles defendiam a necessidade de fundar uma nação que superasse os traumas causados pelos atrasos do regime colonial. E, a partir dessa reconfiguração, vincular ao país emancipado uma identidade capaz de promover valores que correspondessem ao moderno cenário político e social.

Contudo, como nos alerta Beatriz González Stephan ${ }^{8}$, classificar grupos como liberais ou conservadores na América Latina é mover-se em um terreno farto de contradições. Paradoxalmente, havia partidos considerados conservadores que mantinham políticas econômicas liberais e liberais que preservavam políticas conservadoras. Dificilmente se podia distinguir um grupo do outro e a forma indiscriminada de utilizar dessas nomenclaturas para representar as elites opositoras tende a trazer mais confusões do que esclarecimentos. Por isto, a pesquisadora acredita ser mais apropriado falar em "pensamento conservador" e "pensamento liberal”, pois desta maneira delimita-se melhor os valores de cada formação ideológica.

\footnotetext{
7 WASSERMAN, Fabio. "Las prendas geniales de nuestra sociedad: representaciones del pasado e identidad nacional en el discurso de las elites político - letradas chilenas (1840-1860).” In: Revista Ibero Americana año III (2003), n9 p.8

${ }^{8}$ GONZALEZ STEPHAN, Beatriz. Op. Cit.
} 
O estabelecimento desta perspectiva, aqui também adotada, auxilia na compreensão de que o processo de formações ideológicas na América Latina deu-se de maneira diferente dos conflitos europeus. Advindas das classes dominantes, a divisão partidária era muito mais por conveniência do que por razões ideológicas. Na prática, eles se encontravam imbricados e antes de se ligarem aos ideários liberais ou conservadores associavam-se aos seus próprios interesses. Os confrontos orbitavam entorno das disputas para ocupar o espaço deixado pela Espanha. Descendentes desse velho regime, as oligarquias chilenas lutavam pela garantia de sua parte na herança, e movidas muitas vezes pelas circunstâncias, adotavam momentaneamente um ou outro pensamento.

No transcurso da história chilena, os conflitos de interesses relacionaram-se a importantes acontecimentos que marcaram a década de 1830, e consequentemente transformaram as décadas seguintes. Seguindo a ordem cronológica, em 1837 aconteceu o motim liberal que culminou no assassinato de Diego Portales. Com a morte do líder, o partido conservador passou a ser mais flexível com algumas restrições impostas aos antigos opositores. Dois anos depois, em 1839, num dos mais sangrentos combates da época, o Chile sairia vitorioso da guerra contra a Confederação Peru-Bolívia e com o fim do conflito o país conheceria uma longa prosperidade econômica. ${ }^{9}$

A política mais maleável e o êxito financeiro foram fundamentais para determinar muitas das transformações reivindicadas pelo pensamento liberal. Pois foi precisamente após os mencionados acontecimentos, quando se deram os mais expressivos empenhos, por parte da iniciativa estatal, por empreender renovações culturais.

A Universidade do Chile, fundada entre os anos de 1842 e 1843, é um exemplo dessa nova política do Estado de introduzir reformas sociais. Para além dessa função, a instituição representou, simbolicamente, uma trégua entre o pensamento conservador e o liberal. Afinal, guardadas as diferenças sobre questões políticas e econômicas, tanto pipiolos como pelucones, que provinham basicamente das mesmas camadas sociais da elite chilena, concordavam com a relação entre educação, civilização e progresso. Com o auxílio das reflexões do historiador Fabio Wasserman, podemos ter uma ideia mais precisa dos interesses comuns desses grupos entorno do novo símbolo republicano que anunciava "la existencia de un horizonte ideológico en

\footnotetext{
${ }^{9}$ Ver WASSERMAN. Fabio. Op. Cit.
} 
común dentro del cual los miembros de la elite podían articular diversas propuestas”. 10

Uma destas propostas era priorizar a relação entre a população do país com os novos símbolos, espaços e tempos. A Instituição foi criada com uma função estratégica de incidir e interferir na vida cotidiana da nação. Através dela desejava-se erguer ambientes e contextos sociais inteiramente renovados que representassem a civilização; quase como numa transformação plástica, pretendia-se enxertar, na pele do rosto rugoso, uma cútis infantil, sem linhas e traços que remetessem à história passada. A República chilena passava por uma cirurgia estética para corrigir as imperfeições e as expectativas eram de que os bisturis da educação atuassem em todas as camadas da epiderme social. No entanto, as camadas mais profundas do colonialismo não foram essencialmente alteradas, as intervenções para a remodelação dos traços da sociedade tradicional apenas forjavam uma nova realidade:

Desde 1840 el Estado inició una fuerte política de escolarización, cuyo objetivo queremos sugerir era romper los lazos comunitarios de tipo tradicional y forjar unos nuevos, basados en la racionalidad de la cultura escrita: era construir una sociedad de individuos que se comportasen racionalmente en el espacio privado identificado y el trabajo, en el espacio público identificado con ciudadanía y la manutención del orden social ${ }^{11}$.

Submetida à máxima da educação salvadora, a implementação e reformulação da Universidade expandia o sentido da instituição de ensino para assegurar o requerido papel de transformador social. Nessa atmosfera um tanto eufórica de formação da consciência nacional e modernização social, muitos intelectuais de países vizinhos encontraram no Chile o ambiente propício para desenvolver suas atividades. A título de exemplo, podemos citar as figuras de dois estrangeiros que participaram ativamente do projeto nacionalista: o venezuelano Andrés Bello e o argentino Domingo F. Sarmiento, que ao lado dos irmãos Francisco e Manuel Bilbao, Eusébio Lillo e outros intelectuais chilenos, protagonizaram o movimento liberal liderado por Victorino Lastarria. Historicamente, este grupo ficaria conhecido como a geração de 1842.

\footnotetext{
${ }^{10}$ Ibid. p. 9.

11 SERRANO, SOL. "Universidad y Nación. Chile en el siglo XIX." Santiago de Chile: Editorial Universitaria. 1993. pp. 341-342. Apud WASSERMAN. Fabio. "Las prendas geniales de nuestra sociedad" representaciones del pasado e identidad nacional en el discurso de las elites político- letradas chilenas (1840-1860).” In: Revista Ibero Americana año III (2003) n9, p.12.
} 
Algumas polêmicas do período foram marcadas pelas propostas antitéticas de Andrés Bello e Sarmiento sobre a concepção do projeto de transformação nacional. Embora traçando o mesmo ideal civilizador, os dois intelectuais optavam por caminhos diferentes. Bello, do seu lugar de primeiro reitor da Universidade do Chile e de sua formação clássica acadêmica, defendia um processo educacional institucional e erudito, baseado no conhecimento formal e científico. Já Sarmiento, um intelectual autodidata, assumia outra postura em relação à educação, pois acreditava que esta não estava unicamente relacionada ao ensino institucional e que os cidadãos também poderiam ser educados por recursos extrainstitucionais, como o incentivo à leitura.

Essas controvérsias sustentaram calorosos e interessantes debates, que iam além de "esquemas simplificadores que contraponen un Sarmiento romántico - pegado a la vida - a la figura ascética de Bello, guardián de la forma”. ${ }^{12}$ Entretanto, não nos aprofundaremos nessa discussão, seguiremos debruçando-nos sobre a popularização do saber idealizada por Sarmiento, mas sem negar a influência de Andrés Bello no cenário intelectual chileno.

Manuel Montt, o então Ministro da Justiça, Culto e Instrução Pública, que viria a ser presidente da República pelo partido conservador entre 1851-1861, enviou Sarmiento aos Estados Unidos e à Europa para pesquisar formas e estratégias de aperfeiçoar a educação no país. Nessas viagens, ele acompanhou uma realidade muito distinta da encontrada no Chile. "Su diagnóstico fue que Chile estaba aún en su infancia en términos de difusión de las ideas." 13

Diante da disparidade que ele observara entre a nação chilena e os países por ele visitados, Sarmiento efetuou a seguinte constatação: por trás do atraso do progresso chileno havia duas grandezas diretamente proporcionais. Simplificando essa equação, a falta de instrução dos cidadãos chilenos era diretamente proporcional ao atraso civilizatório. De modo que essas variáveis, as quais cresciam em mesmo sentido, só conseguiriam atingir o equilíbrio se os problemas educacionais fossem solucionados, ou seja, o aumento do número de cidadãos instruídos implicaria diretamente na ampliação do progresso.

Apesar da facilidade lógica para equiparar as variantes dependentes, a solução da equação esbarrava em diversos obstáculos que ultrapassavam o saber matemático.

\footnotetext{
${ }^{12}$ RAMOS, Julio. Desencuentros de la modernidad en América Latina- Literatura y política en el siglo XIX. México: Fondo de Cultura Económica, 1989, p. 35.

${ }^{13}$ STUVEN, Ana María. La seducción de un orden. Santiago de Chile: Ediciones Universidad Católica de Chile, 2000, p. 120.
} 
Em outras palavras, havia muitos percalços advindos da dificuldade de transplantar uma cultura letrada, que os novos ares modernos clamavam com urgência, dentro de uma comunidade que acabava de sair de um regime colonial e ainda carregava uma forte tradição oral.

Para superar esse desafio, Sarmiento apostou no incentivo ao hábito da leitura para desenvolver a educação nos mais amplos setores sociais. Defendeu o atrativo dos folhetins, novelas e romances como estimuladores e introdutores da cultura letrada, considerando essas vias mais agradáveis para iniciar o gosto pela leitura: “millares no leen. Sólo novelas-folletín ayudan a vencer esta dificultad y la vencen... Las novelas y los diarios han cumplido esa función... Soulié, Dumas, Balzac han estado enseñando a leer a la América del Sur, que para leer sus novelas-folletines se ha convertido en una vasta escuela."14

Sarmiento reconhece que os folhetins não trazem bons exemplos morais, mas os exime de todas as culpas, dizendo que perdoa “hasta a las malas [novelas] pues ellas nos han enseñado a leer y han sido, en consecuencia útiles y serviciales al cultivo de la inteligencia.” ${ }^{15}$ Pois segundo ele nada adiantaria submeter o povo a livros eruditos, morais ou religiosos:

[...] no puede 'Ilevarse(le)' por la fuerza y 'maniatado' a la biblioteca, a leer lo que nada le mueve a leer. ¿Es moral el libro, es serio, es útil? Razón de más para no leerlo. El pueblo, es decir, el que no tiene el hábito de leer, comienza a leer uno de esos libros tan recomendados y principia por bostezar y acaba por dormirse. ${ }^{16}$

Os dados sobre escolaridade na cidade de Santiago, no início do século XIX, demonstram os efeitos da realização do projeto através do incentivo à leitura de romances e folhetins. A população santiaguina era, em 1831, de aproximadamente 85.000 habitantes e as escolas da cidade tinham 5.700 alunos, este número saltaria para 43.000 em 1861. O índice de alfabetização em 1854 era de 17\% da população masculina e $10 \%$ da população feminina. Em dez anos, essas cifras passaram para $20 \%$ da população masculina e $14 \%$ da população feminina ${ }^{17}$.

\footnotetext{
${ }^{14}$ Sarmiento In: SUBERCARSEAUX, Bernardo. Historia del libro en Chile (Alma y Cuerpo). Santiago de Chile: Editorial Andrés Bello, 1993. p. 58.

${ }^{15}$ Ibid., p. 58.

${ }^{16}$ Ibid., p. 57.

${ }^{17}$ Dados retirados de: ZANETTI, Susana. La dorada garra de la lectura- lectoras y lectores de novela en América latina. Rosario: Beatriz Viterbo, 2002.
} 
O nascente público leitor incentivou a expansão do comércio de livros e em 1849, a cidade de Valparaíso contava com pelo menos cinco livrarias e em Santiago havia outras tantas. Entre elas destacava-se a dos irmãos Cueto, que oferecia um catálogo variado de 2.741 títulos à venda.

\section{1-UM PROJETO PARA LITERATURA NACIONAL}

Todo esse clima de incentivo à leitura também abriu espaço para a divulgação e encorajou a produção de obras literárias nacionais que durante o período colonial eram pouco difundidas. Havia poucos escritores locais e suas obras constituíam-se apenas como relatos de viagens, pouco mais que uma dúzia de romances e alguns artigos de costumes. Desse modo, a maior parte do que se lia em terras americanas na época era produzido na Europa ${ }^{18}$.

Se o modelo literário era o europeu, parece-nos natural que as nações latinoamericanas tenham se prendido a este protótipo para começar a escrever suas próprias literaturas. Dentro desse este olhar, Leyla Perrone-Moisés coloca em relevo uma questão estrutural que transpassa toda ideia de literatura nacional e esbarra num problema identitário, que se caracteriza pela falta de distanciamento com o liame europeu. Por esta razão, ela afirma: "literaturas latino-americanas foram forçadas, desde o início, a enfrentar a questão identitária, a se debater entre as instâncias do Mesmo e do Outro". 19

A antítese do mesmo e do outro parece ser a expressão que melhor traduz as contradições constituintes dos intelectuais latino-americanos do século XIX. Embora nascidos na América, eles receberam de algum modo, a influência das diretrizes da educação europeia em suas formações. Altamente inspirados pela antiga cultura, sentem-se como os mesmos, porém quando se deparam com suas nações independentes sentem-se como outros. Levados por este encadeamento dialético forjam a síntese.

\footnotetext{
${ }^{18}$ Ver SCHWARZ, Roberto. Ao vencedor as Batatas. Formas literárias e processo social nos inícios do romance brasileiro. São Paulo: Editora 34, 2000.

${ }^{19}$ PERRONE-MOISÉS. Leyla. op.cit., 2007 p. 29
} 
Assim como as demais nações recém-independentes, a República do Chile herdara o produto literário do Velho Mundo, o que no sentido essencial representa um vínculo indissolúvel com o projeto de criação da literatura nacional. Na tentativa de construir uma literatura autenticamente nacional, as primeiras produções chilenas foram inflamadas por um sentimento nacional patriótico, marcado por uma visão anticolonialista.

Contudo, se há um reconhecido esforço para construir uma autoimagem chilena, percebe-se a falta desse mesmo empenho na construção de uma representação enunciativa própria. Isto talvez tenha sua razão na urgência de não só construir uma literatura nacional, mas também erigir, no conjunto de uma missão mais ampla, uma pátria e uma literatura, como aponta Antonio Candido na Formação da Literatura Brasileira $^{20}$. Isto em termos de uma concepção liberal, para a qual o desígnio indicado à literatura seria uma espécie de culto prestado ao nacionalismo para individualizar e especificar as nações.

Paralela a esta dupla missão atribuída à literatura, vinha a intenção de criar uma pátria/literatura que aos olhos europeus não fosse uma cópia, mas também não fosse barbárie, e que ao menos fosse reconhecida por seu valor. De fato pode-se notar que as articulações da autoimagem chilena tendem mais para um argumento temático do que formal. Não há transformações estruturais, a voz que narra o Chile é a mesma que vinha contando a Europa. Nessa medida, temos a expressão exterior tanto no que se refere à literatura, quanto às propostas de fundação da nação.

O Novo Mundo ergue-se através do Velho, pois já não é possível recuperar um passado quase totalmente exterminado pelas Guerras da Conquista e tampouco é possível negar a relação de aproximadamente três séculos de colonização e imigrações europeias. Sem um lugar identitário próprio tomava-se de empréstimo a língua espanhola e os formatos da literatura europeia para escrever a história da recém-nação chilena que paradoxalmente não tinha história.

A relação estreita da literatura com o pretendido efeito de "verdade histórica" privilegiou a transplantação de correntes literárias mais ligadas ao movimento realista. Por esta razão há muitas controvérsias sobre se houve ou não no Chile o que se possa denominar literatura romântica. Contudo, podemos reconhecer nesse empenho nacionalista, diversos traços do pensamento romântico, principalmente no que toca às

\footnotetext{
${ }^{20}$ Ver Antonio Candido. Formação da Literatura Brasileira. São Paulo: Editora Ouro sobre Azul, 2004.
} 
questões estruturais e discursivas. Beatriz González Stephan acredita que a tendência ao idealismo foi uma solução retirada do abstrativismo romântico para contornar a inadequação dos princípios liberais à realidade; diz ela: La deformación del pensamiento liberal llevó al culto de la subjetividad, del mundo interior, al hedonismo, y a posiciones contemplativas de la vida. ${ }^{21}$

Sob a luz de um realismo dito romântico, as preocupações com a história e costumes embasam os romances, que os intelectuais da época reconheciam como nacionais. Entretanto, quando se analisam os textos do continente americano, é necessário antes de tudo, superar uma atitude mecanicamente comparatista. Os problemas de definições esbarram sempre em barreiras artificiais e não muito funcionais. Ainda mais se tratando de tradições muitas vezes herdadas ou impostas. O passado clássico, medieval, iluminista e romântico pesa sobre a América e principalmente sobre os americanos que pretendiam desenvolver a literatura local.

\section{2- BLest GanA}

Filho do médico irlandês Guilhermo Blest e da descente de espanhóis Maria de la Luz Gana, a educação do escritor teve forte marca europeia pela influência paterna. São inúmeros os relatos sobre as sessões de leitura de escritores ingleses, principalmente a leitura de Walter Scott, promovidas pelo pai. Em 1843, ingressou no Instituto Nacional, uma das mais importantes instituições educacionais do Chile. Pouco depois, estudou na escola Militar e no ano 1847 ganhou uma bolsa de estudos para concluir o curso de engenharia militar na França.

Essa primeira estada de Blest Gana na França foi exclusivamente dedicada à sua formação militar. O ainda estudante permaneceria alheio aos importantes acontecimentos políticos e literários que antecederam e culminaram na revolução de 1848. Somente anos mais tarde, quando retornou ao Chile, após abandonar definitivamente a profissão de militar para dar seus primeiros passos em direção à carreira literária, ele aderiria aos apelos do ideário da revolução liberal francesa.

\footnotetext{
${ }^{21}$ GONZALEZ STEPHAN. Op.Cit.1987. p. 58.
} 
Sabe-se que apesar de Blest Gana ter permanecido distante, tanto das agitações de Paris como dos conflitos chilenos da Revolução Liberal de 1851, estes foram determinantes para que ele, posteriormente, tomado pelo clima que pairava em seu país, passasse a defender a causa liberal, como tantos outros escritores e intelectuais latinoamericanos de sua época que de algum modo assimilavam as notícias vindas da Europa. O envolvimento com a causa liberal foi um dos aspectos ideológicos que marcaram sua obra e também de certa forma encaminharam a denominação de fundador da literatura chilena, em termos de sua emancipação pós-colonial.

Sua primeira aparição como escritor foi como colaborador no Jornal recémfundado, “El Museo”, periódico especializado em literatura e estudos científicos, no qual Blest Gana apresentava, em meio a pequenos artigos, alguns de seus versos rimados. Como romancista, sua primeira atuação foi no ano de 1853, com a publicação do romance Una escena social. Entre os anos de 1855 e 1859, ele já era um nome conhecido pelo seu ofício de escritor. Neste período, foram publicados seis romances, um drama e vários artigos de costumes, produção expressiva para os padrões latinoamericanos da época, embora isso de pouco lhe valesse financeiramente. Em carta enviada em 25 de Janeiro de 1864, ao amigo ex-ministro da Fazenda José Victorino Lastarria, o escritor reclama da falta de incentivo e apoio financeiro:

Que Chile lea mis novelas sin cuidarse del estado de mi bolsillo es cosa triste para el que carga este último vacío; pero que un gobierno de los nuestros no se acuerde, para mejorar mi suerte, de once años de servicios constantes, me parece más triste todavía. ${ }^{22}$

Blest Gana faz alusão aqui aos serviços ininterruptos prestados como representante do governo chileno no exterior. Mesmo com uma produção digna de um escritor profissional, seus livros não garantiam seu sustento e, ao longo de toda sua carreira, sempre teve que exercer atividades paralelas à de romancista. Entre $1864 \mathrm{e}$ $1878^{23}$, ele deixaria de lado a literatura para se dedicar durante mais de trinta anos, com exclusividade, às suas atividades diplomáticas em Paris. Mesmo tendo sido consagrado com o prêmio nacional em 1860, pelo romance La Aritmética en el amor, o título não lhe rendeu o reconhecimento financeiro.

\footnotetext{
${ }^{22}$ FERNANDEZ, Larraín Sergio (org). Epistolário Aberto Blest Gana 1856-1903. Editora Universitária: Santiago de Chile, 1991. p 56.

${ }^{23}$ Ano em que publica o longo romance Durante la Reconquista.
} 
O concurso tinha sido organizado pela Universidade do Chile, instituição que, como dissemos, desempenhava um papel central no desenvolvimento cultural chileno e reunia e sistematizava práticas, discursos e saberes. Até a década de 1850, os estudos históricos ocupavam, quase exclusivamente, os esforços dos intelectuais, que se empenhavam em recuperar documentos e testemunhos para escrever a história da nova nação. Nos anos posteriores, estes esforços foram ampliados para o campo literário. A intenção era dar mais solidez à tradição literária e utilizá-la como elemento divulgador da nascente nação. Neste sentido, a convocação do primeiro concurso de literatura nacional era um passo para que a história e a literatura pudessem juntas promover a nacionalização do Estado chileno.

O propósito era dar relevância à literatura em prosa e retirar da cena principal a lírica romântica, cujos sentidos poéticos eram considerados pouco representativos da expressão da sociedade chilena. Com intuito de dar um salto do individual para o social, o concurso exigia a apresentação de "um romance em prosa, histórico ou de costumes com quadros e personagens autenticamente chilenos”24. O júri foi integrado por Miguel Luis Amunátegui, historiador liberal e professor da Universidade do Chile, e pelo liberal José Victorino Lastarria que, além de seu papel político, acabaria se transformando num dos maiores impulsores da literatura chilena, integrando o primeiro grupo de intelectuais e escritores interessados na elaboração de produções nacionais.

Vitorioso, o romance La Aritmética en el amor não é exatamente o que se pode chamar de uma narrativa nacional, já que seu enredo poderia facilmente acontecer em um cenário europeu. Mas com toda certeza encontram-se nele saborosas cenas da sociedade santiaguina do século XIX, que demonstram um esforço do autor para destacar a tonalidade local que as bases do concurso requeriam para assim impulsionar a criação de uma literatura chilena.

Em linhas gerais, o argumento do romance, dentro dos moldes mais típicos do folhetim, traz a vida de Fortunato Esperanzo, um ambicioso e vaidoso jovem que busca enriquecer por meio do casamento. As peripécias que acompanham sua trajetória apresentam as aventuras desse protagonista em busca da ascensão social e financeira. Dividido entre o amor e o dinheiro, Fortunato ${ }^{25}$ acaba preferindo o segundo. O jovem afasta-se da humilde namorada, Amelia Almiro, para flertar com a jovem herdeira,

\footnotetext{
${ }^{24}$ SUBERCASEAUX. Bernardo. Historia de las Ideas y de la Cultura em Chile. Tomo I Sociedad y cultura liberal el siglo XIX: J. V. Lastarria. Editorial Universitaria. 1997, p. 146.

${ }^{25}$ Não por acaso, Fortunato inclui ‘fortuna' dentro do próprio nome.
} 
senhorita Mantoverde, mas a carência de nobreza de Fortunato inviabiliza a união. Após diversas tentativas fracassadas de aproximar-se de outras jovens dos salões aristocráticos, o caça-fortuna entrega-se ao seu verdadeiro amor, Amelia Almiro, e para brindar um final feliz, acaba herdando inesperadamente à fortuna de um tio rico.

Nos romances seguintes, Martín Rivas $(1862)^{26}$ e El ideal de un Calavera (1863), as características nacionais, que o modelo da época demandava, estão mais integradas às narrativas. As tramas possuem quadros de costumes mais elaborados que têm como pano de fundo dois importantes momentos da história dos liberais no Chile. No primeiro romance a Revolução Liberal de 1851 e no segundo, o Motim de 1837 que foi responsável pela morte do grande líder conservador Diego Portales.

Esses três romances, pensados por muitos como uma trilogia ${ }^{27}$, inserem-se numa fase da produção do escritor que marca a conjunção dos apelos ideológicos assim como de outros pontos bastante acentuados e apresentados pela crítica, quais sejam as influências estilísticas de Stendhal, Scott e principalmente Balzac, pensando por exemplo, na utilização de digressões lírico-filosóficas.

Embora não saibamos precisamente quais e quantos foram os romances lidos por Blest Gana, sabemos que foi um bom leitor de Balzac, pois as leituras das obras do romancista francês representaram uma verdadeira virada nas produções do autor. Tanto foi assim, que Blest Gana, em um empolgante “auto de fé”, queimaria todos os seus poemas juvenis, prometendo seguir os passos do realista de Tours. O episódio é relatado por ele próprio em carta ao amigo Vicuña Mackenna em 7 de janeiro de 1864:

desde un día en que leyendo a Balzac hice un auto de fe en mi chimenea, condenando a las llamas las impresiones rimadas de mi adolescencia, juré ser novelista y abandonar el campo si las fuerzas no me alcanzaban para hacer algo que no fuesen triviales $y$ pasajeras composiciones. Desde entonces he seguido, incansable como tú dices, mi propósito, sin irritarme con la crítica, sin enorgullecerme tampoco por los aplausos con que el público ha saludado mis últimas novelas. ${ }^{28}$

Decisão muito ousada, mas bastante consciente. Blest Gana prontamente reconheceu e separou os pontos a favor e em contra da importação do estilo

\footnotetext{
${ }^{26}$ A consagração como “o pai da literatura chilena” viria depois, com este romance.

${ }^{27}$ Hernand Poblete Varas assim denomina as três obras La Aritimética en el Amor, Martín Rivas e El ideal de un Calavera. In: prólogo da edição de El ideal de un Calavera: Editorial Andrés Bello: Santiago de Chile, 1999.

${ }^{28}$ FERNANDEZ, Larraín Sergio. Op. Cit. p. 55.
} 
balzaquiano. No discurso proferido por ele em 1861, ao tomar posse da cadeira de Ciências Humanas na Universidade do Chile, afirmava a necessidade de realizar adaptações ao modelo estrangeiro:

Es un error manifiesto decir que la novela no prospera entre nosotros porque el estado transitorio de nuestra sociedad no ofrece argumentos interesantes, o por ser reducida, hay peligro de retratar a lo vivo que en ella acaece. En las conversaciones, en la observación interior, en las reuniones sociales, en los periódicos, en la vida ordinaria, puede hallarse en cualquier momento asunto para cien novelas. ${ }^{29}$

Diferentemente da “fisionomia” francesa, o país chileno do oitocentos estava, de fato, muito aquém do intrincado jogo de interesses que movia as peças do tabuleiro francês. Entretanto, Blest Gana não se intimidou com o que poderia ser considerada uma desvantagem e seguindo os passos de Balzac, debruçou-se sobre seu meio social e observou as intrigas dos acontecimentos cotidianos com bastante sensibilidade para reconhecer a essência do modelo. Ele fez da sociedade chilena a grande matéria de seus romances. Mesmo com as diferenças entre a sociedade francesa e a chilena, Blest Gana soube adaptá-las ao cenário pós-colonial, como afirmará Ricardo Latcham em seu livro Blest Gana y la novela realista ${ }^{30}$.

As cenas da vida cotidiana formam os enredos para compor suas narrativas. Através da representação de pequenos quadros sociais, as contradições e incoerências da recente nação vão sendo inseridas em seus romances. Porém, mais do que parte conscientemente constitutiva, essas mesmas contradições e incoerências vêm embutidas na própria enunciação e a cada avanço e recuo das peripécias. Ou seja, não há uma intencionalidade de reproduzir a falta de conciliação com os anseios liberais, pelo contrário, o propósito é mais o de naturalizar as aspirações que encaminhariam em direção à batalha civilizadora, projeto no qual ele tanto parecia acreditar.

Parte dessas incoerências, encontradas em suas tramas, parece ter uma ligação com a escolha da forma, pois junto com a adaptação da fórmula balzaquiana vieram também todas as contradições que acompanham as narrativas do gigante de Tours. Balzac, que era declaradamente a favor do ancien regime critica o liberalismo em todas suas obras; usura, especulações imobiliárias foram para ele as novas rodas que

\footnotetext{
${ }^{29}$ CASTRO, Silva Raul. História Crítica de la novela chilena. 1843-1956 Madrid: Ediciones Cultura hispanica, 1960. p.18.

${ }^{30}$ LATCHAM, A, Ricardo. Blest Gana y la novela realista. Santiago de Chile: Ediciones de los anales de la Universidad de Chile, 1958. p. 9.
} 
lamentavelmente passavam a movimentar o mundo. No entanto, o que surge como uma crítica à subordinação social ao dinheiro termina virando uma visão revolucionária, pois se Balzac não foi o primeiro, sem dúvida foi um dos pioneiros a levar para dentro de suas narrativas a possibilidade de mobilidade social. Balzac pode não ter sido um liberal, mas o mesmo não pode ser dito de sua literatura.

Numa escala menor, isto também ocorre com o projeto de literatura nacional de Blest Gana que de maneira alguma é homogeneamente liberal. Na acertada análise de Laura Janina Hosiasson, ela nos aponta que: lejos de ser uniforme y coherente, está repleto de contradiciones que el mismo escritor fue tranformando en materia literaria. ${ }^{31}$ Daí as contradições também serem sempre um ponto presente em suas narrativas.

Movido por suas pretensões civilizadoras, plasmadas num discurso de construção de uma literatura autenticamente chilena, Blest Gana realizou um inventário do meio social, sobre o qual imprimiu a "terrestre comédia”32, expressão comumente empregada por seus narradores em alusão direta à Comédia Humana de Balzac. Em seu inventário social, há tipos variados de personagens, desde o típico jovem provinciano Martín Rivas - que busca a ascensão social na grande cidade, à maneira de Lucien de Rubempré e Eugène de Rastignac, até a autenticidade e a ambiguidade que veremos na figura do Calavera Abelardo Manríquez.

Um destaque também deve ser dado aos narradores que apresentam sempre uma voz expressiva e irônica diante dos acontecimentos. Oniscientes como os narradores balzaquianos, eles também encenam uma consciência responsável pelo mundo narrado. Como se fossem conhecedores de toda verdade, caracterizam as personagens com certa presunção. Minuciosas e afiadas, suas observações revelam as intrigas das tramas, nada parecendo poder escapar aos olhos desses que intermedeiam a nossa leitura. Entre suas conjecturas e intervenções, somos conduzidos aos pensamentos de narradores altamente contraditórios, especialmente, nos romances Maríluán (o único que trata a questão indígena) e El ideal de un Calavera. Nessas duas obras, os narradores se debatem entre a adesão e a negação aos protagonistas, pois tanto um como o outro se chocam de alguma maneira com a idealização da sociedade moderna, para qual a literatura nacional parecia estar a serviço.

\footnotetext{
${ }^{31}$ HOSIASSON, Laura. J. “Blest Gana, Martín y el calavera”. In: Revista Chilena de Literatura. Santiago de Chile: Editorial Universitária Noviembre número 75 noviembre de 2009, p. 262.

${ }^{32}$ GOTSCHLICH, Guillermo Reyes. "Grostesco y tragicomedia en El ideal de un calavera de Alberto Blest Gana”. In: Revista Chilena de literatura. №29 Abril. Ano 1987, p. 121.
} 


\section{CAPÍTULO}

\section{2.- "CALAVERA NO CHILLA"33}

Publicado pelo periódico santiaguino La voz de Chile, em formato de folhetim, El ideal de un Calavera (1863) é a obra que fecha a trilogia completada por La aritmética en el amor (1860) e Martín Rivas (1862). Como acabamos de ver, os três romances representam alguns dos possíveis caminhos que o cenário da recémindependente nação chilena oferecia aos seus jovens cidadãos. La aritmética en el amor retrata os jovens caçadores de dotes que pretendem encontrar no casamento a prosperidade. Em Martín Rivas, acompanhamos a ascensão do provinciano que abandona o campo para estudar em Santiago e em El ideal, temos a figura impar do calavera .

Pela tradução etimológica, a palavra calavera remete a crânio ou caveira, e no sentido figurado designa um hombre de mala vida. No verbete do dicionário etimológico Corominas, encontramos a afirmação de que, por uma dessas metáforas tão presentes nas línguas orientais, mas estranhas ao léxico ocidental, a palavra calavera, na acepção aqui empregada, tem sua origem no árabe vulgar e por um decalque semântico do vocábulo utilizado em árabe, qahûf, ganhou o mesmo sentido em espanhol ${ }^{34}$. Assim, no sentido figurado, no qual Blest Gana se baseia, calavera é um tipo social conhecido por seu caráter libertino e imoral, muito próximo à figura do nosso malandro brasileiro. Este calavera é Abelardo Manríquez, cuja figura se distancia tanto da imagem de Fortunato Esperanzo, o ambicioso caçador de dote, como do bom moço e estudioso, Martín Rivas.

\footnotetext{
33 Trata-se de uma expressão latino-americana que deve ter ao menos 150 anos. Calavera refere-se a um tipo social que gosta da noite e da farra, "no chilla" é como dizer que não se pode queixar, ou seja, se gosta de sair à noite no outro dia não reclame, que dói a cabeça, que tem sono no trabalho, etc.

${ }^{34}$ Dados retirados do Diccionario Crítico Etimológico castellano e hispano. Volume I. Joan Corominas. Colaborador José A Pascual. Madrid: Editorial Gredos, 1991. $3^{\circ}$ ed. Tomo I.
} 
Com a publicação do El ideal de un Calavera, Blest Gana objetivava pular os limites da pátria e tornar-se conhecido por toda América. Em uma carta datada de 7 de Dezembro de 1863, o autor comenta com o amigo, e também escritor José Antonio Donoso, suas pretensões de ampliar seu público de leitores. Nessa direção, pede-lhe que escreva um artigo, para ser publicado em um dos grandes jornais de circulação da época para desse modo dar maior publicidade ao romance:

Mi querido amigo José Antonio:

Por el correo que lleva ésta te remito un ejemplar de El ideal de un calavera. En vez de pedirte tu opinión privada acerca de esta obra, te

agradecería infinito sacudieses tu pereza y me la dieses esa opinión en un artículo que yo haré publicar en El Mercurio o en La Patria, a fin de dar a mi libro la mayor publicidad posible. Para juzgar la novela prescinde del amigo y acuérdate sólo del escritor. En cartas y tratando de otros trabajos míos anteriores, me has dado pruebas de esa independencia. ¿Por qué no la tendrías ahora hablando a público? Tú que también has tenido como dice Charles Nodier Le triste métier de conteur de fabioles, me harás justicia al apreciar lo que te pido: busco lectores y aspiro a que mis novelas salven los límites de la patria y hagan conocer mi nombre en el resto de la América. Que los que me hayan leído me juzguen."35

Os objetivos de Blest Gana não foram alcançados. Com menor destaque que os outros dois romances da trilogia, El ideal, não teve a mesma publicidade do primeiro, premiado no concurso de literatura nacional, nem tampouco a popularidade de Martín Rivas. Possivelmente, a pequena repercussão da obra tenha se devido mais a um trágico acontecimento do que à desaprovação da crítica, como fora o caso do livro publicado quase simultaneamente com Martín Rivas, o romance Mariluán (1862) que nos oferece uma visão intrigante da face indígena da nação chilena. Através das aventuras de Fermín Mariluán, conhecemos os dilemas do jovem araucano criado e educado entre as duas culturas, que justamente por sua temática indianista e polêmica acabou sendo esquecido.

No dia 08 de Dezembro, três dias antes do término da publicação do folhetim de El ideal de un Calavera, ocorreu o famoso incêndio na Igreja Companhia de Jesus, na esquina de duas centrais ruas de Santiago, Compañía e Bandera, onde atualmente está localizado o Congresso Nacional Chileno. Na ocasião, congregavam-se na Igreja um sem-número de devotos reunidos para celebrar a festa da Inmaculada Concepción.

\footnotetext{
${ }^{35}$ FERNANDEZ, Larraín, Sergio. Op. Cit. p. 51.
} 
Em meio ao tumulto, morreram queimadas e intoxicadas pela fumaça centenas de pessoas que tentavam escapar pela porta principal da igreja e se chocavam com aqueles, que sem saber do desastre, aventuravam-se a entrar.

O contexto de comoção nacional pelas vítimas do acidente (mais de duas mil pessoas) silenciou a população chilena. Famílias inteiras assistiam à missa. Numa cidade com pouco mais de 85 mil habitantes, depois da tragédia, era raro encontrar um cidadão que não estivesse de luto por algum parente ou amigo próximo. Por isso, somente em janeiro de 1864, apareceu na imprensa o único artigo da época sobre o romance, escrito pelo historiador Bejamín Vicuña Mackenna. O artigo ocupou cinco páginas do jornal El Mercurio, mas não chegou a representar uma grande contribuição para o conhecimento público da obra. Na verdade, Vicuña Mackenna escreve mais sobre sua relação de amizade com Blest Gana do que sobre o romance. A carta que Blest Gana enviou ao amigo em resposta ao artigo teve maior destaque que o próprio artigo de Vicuña Mackena, pois foi exatamente a partir desta carta que o autor confidenciaria publicamente a influência de Balzac em suas obras.

Contudo, e apesar do incêndio da Iglesia de la Compañía de Jesús “no dejó tiempo ni oportunidad para celebrar hazañas literarias”,36, a crítica posterior reconhece, através da leitura das aventuras do jovem calavera, um expressivo amadurecimento da escrita de Blest Gana. Dividido em quatro partes: I Escenas del Campo, II Los Calaveras, III El Ideal e IV Conclusión, o romance destaca-se por apresentar a tão solicitada cor local, não apenas pelos acontecimentos históricos, mas também pela tonalidade nacional que colore todas as personagens, com destaque para os quadros da classe do medio pelo. ${ }^{37}$

Abelardo Manríquez parece-nos uma das personagens mais ambíguas de Blest Gana, conseguindo ao mesmo tempo atrair os olhares femininos e a simpatia dos seus rivais. Contraditório e sem caráter, ele não mede esforços para alcançar o que deseja, contudo, apresenta uma nobreza de coração e de sentimentos que conquistam e sensibilizam até mesmo os leitores.

Antes de prosseguir, gostaríamos apenas de frisar um ponto que será retomado e aprofundado mais adiante, mas que a partir daqui se torna necessário: a relação intertextual entre a composição da personagem Abelardo Manríquez e a

\footnotetext{
${ }^{36}$ POBLETE, Varas Hernán. Genio y figura de Alberto Blest Gana. Editorial Universidad de Buenos Aires: Buenos Aires, 1968 p.154.

${ }^{37}$ Medio pelo é uma maneira pejorativa de referenciar a classe média que se diferencia das classes mais baixas.
} 
Correspondência de Abelardo e Heloísa que se constitui em ponto de partida para a compreensão que aqui se quer elaborar a respeito desta ambígua personagem.

A conexão do ideal do protagonista com as cartas de amor trocadas no século XII entre o abade francês e sua amante aparece explícita ao longo de todo o romance. A partir da leitura dessa obra, feita pelo jovem calavera, tentaremos demonstrar como a personagem-leitor, se espelha na história de amor de Abelardo e Heloísa, tomando-a como modelo para sua própria vida, relacionando suas leituras com a composição de seu ideal de amor.

\section{1.- AdVERTÊNCIAS PARA A Literatura CHILENA}

Para a realização da pesquisa, foram confrontadas duas edições de El ideal de un calavera: uma de $1908^{38}$, e a outra publicada mais recentemente, em $1999^{39}$. Na edição de 1908, as quase 700 páginas estão divididas em dois tomos, precedidos por uma advertência e uma dedicatória que foram, lamentavelmente, suprimidas na edição de 1999.

Na advertência que abre a obra, Blest Gana não se dirige apenas aos leitores, mas também àqueles que, segundo ele, herdarão o seu legado e seguirão a marcha de sua pena, dedicando-se a escrever a literatura chilena. Facilmente, essas considerações poderiam ser incluídas em um manifesto para obras de caráter nacional: "mi fé en el talento de los que nos han de seguir en esta vía, me hace esperar que sabrán poblar con útiles y fecundas invenciones, el espacio que nosotros dejamos sólo delineado como fundadores." 40

Percebemos por essas linhas que Blest Gana reconhece em seus trabalhos o papel fundador da literatura de seu país, de modo que nos parece interessante reparar como em diversos momentos ele reivindica em seus discursos a imagem de pai da literatura chilena. Apesar de esta imagem da paternidade corresponder mais a uma construção do que a uma situação de fato, isto não invalida, a relevância do autor, que

\footnotetext{
${ }^{38}$ El ideal de un calavera. Novela de Costumbres, $3^{\circ}$ edição. Librería de la V.da de CH. Bouret: Paris, 1908.

${ }^{39}$ El ideal de un Calavera. Chile: Editorial Andrés Bello, 1999.

${ }^{40}$ BLEST, Gana. Op. Cit. Tomo I, 1908 P. VII
} 
sem dúvida ocupa um lugar de destaque em todas as historiografias literárias da América Latina. Suas produções foram um marco nos romances de costumes no Chile, o que de algum modo representou também o desabrochar de um simbólico nascimento que era aguardado por muitos intelectuais do período.

O grande anseio da recente nação, de marcar as próprias características, fez dos romances de costumes o verdadeiro expoente da literatura nacional. Naturalmente percebe-se, por esse arranjo inaugural da literatura chilena, uma íntima ligação entre literatura e nação, ligação esta que a princípio parece muito lógica, mas que corresponde à ilusão de interdependência entre literatura e nacionalismo, ou seja, de que um se apoia no outro. Reverberando como uma única possibilidade de existência, quase como se não pudesse haver literatura sem nação ou nação sem literatura. Leyla Perrone-Moíses nos lembra que: “A literatura mexicana não precisou esperar a Independência para ter Sor Juana Inés de la Cruz, nem a brasileira para ter Gregório de Matos, e ambos deram ao Barroco uma alta e original realização" 41

Ao encontro do que nos diz Leyla Perrone-Moíses, Beatriz González Stephan desenvolve a ideia de que a relação da literatura com a nação é arbitrária e que não existe uma relação de causa e efeito, pelo contrário, trata-se de uma construção forjada pela tradição do pensamento liberal. Afinal, é difícil estabelecer os limites e as fronteiras da literatura de cada região, ainda mais se pensarmos na América-hispânica como uma única só colônia que, posteriormente, foi divida em distintas nações, mas que continuaram a utilizar a mesma língua para escrever suas literaturas.

Daí a tentativa de encorajar, com auxílio dos romances de costumes, a construção de uma identidade singular para cada nação. A escolha pelas narrativas de costumes era bastante conveniente para retratar a sociedade chilena e caracterizar as particularidades que se revelam nos espaços e nas personagens estabelecidos pelo momento histórico. Mas, de outro lado, o mesmo procedimento narrativo parecia ser o atrativo certeiro para conquistar novos leitores e ser um agente transformador da sociedade. Neste sentido, as palavras de Blest Gana na Advertência do romance El ideal de un Calavera seguem a mesma linha do discurso de posse na Faculdade de Humanidades:

Mientras que la poesía conserva siempre para el vulgo la apariencia de los antiguos ídolos cuyo lenguaje era comprensible únicamente a

\footnotetext{
${ }^{41}$ PERRONE-MOISÉS. Leyla. Op. Cit. pp. 34-35.
} 
los sacerdotes del culto pagano, la novela por el contrario, tiene un especial encanto para toda clase de inteligencias, habla el lenguaje de todos, pinta cuadros que cada cual puede a su manera comprender i aplicar, i lleva la civilización hasta las clases menos cultas de la sociedad, por el atractivo de escenas de la vida ordinaria contadas en un lenguaje fácil y sencillo. ${ }^{42}$ (sic)

Assim, segundo o autor de Martín Rivas, seriam as cenas de costumes as que melhor retratariam as paixões humanas, já que seus vaivéns, e as constantes transformações, oferecerem ao escritor uma excelente oportunidade de demonstrar em ação as consequências de determinados atos, os que provocam reflexões na população e dessa forma, para além do mero passatempo, o romance traria consigo uma utilidade social que claramente era a de civilizar e modernizar os hábitos da população chilena.

A advertência aos futuros escritores é um apelo ao seguimento da literatura liberal, cujo propósito era revestir a obra de um caráter essencialmente nacional associado ao papel civilizatório. Para tanto, o romancista deveria garantir a originalidade da obra, sendo fundamental não utilizar recursos estranhos ao seu ambiente, mas retirar seus assuntos de argumentos formados em seu próprio meio. Dentro do campo que constitui o fazer literário, Blest Gana nos diz que a substituição da cor local por elementos distantes da realidade nacional comprometem seriamente as estruturas que asseguram a verossimilhança do quadro geral.

Aparte esses elementos, devemos considerar o cuidado artístico, o qual não chega a mencionar com detalhes, mas deixa subentendido que dele também depende a originalidade da obra, e, sobretudo que estaria neste ponto um dos aspectos mais importantes para diferenciar-se do engenho europeu. O conselho geral é equilibrar a ideia que serve de base para o romance com intervenções auxiliares que contribuam para constituir um 'sello de nacionalidad'. As regras para a constituição de produções com esse sello nacional, enunciadas na carta enviada a Donoso, foram especialmente aplicadas na composição de El ideal de un Calavera.

Fundar e ao mesmo tempo delinear o espaço para as novas gerações de escritores parece tarefa árdua e, naturalmente, constituída por erros e acertos. O primeiro romance do escritor Una Escena social-novela original chilena ${ }^{43}$ (1853), tinha

\footnotetext{
${ }^{42}$ BLEST, Alberto Gana. Literatura Chilena. Algunas consideraciones sobre ella. - Discurso de don Alberto Blest Gana en su incorporación a la Facultad de Humanidades, leído en la sesión del 3 de enero de 1861, p. 86.

${ }^{43}$ O subtítulo - novela original chilena - era uma classificação dada a todo o romance escrito por autores nacionais.
} 
sido uma tentativa desastrosa de percorrer os costumes e hábitos da sociedade chilena. Partindo de uma temática de fácil aceitação pelo público, o amor romântico seria o fio que conduziria as pinturas cotidianas da narrativa. Entretanto, ainda jovem e inexperiente, o escritor não soube ali dosar a medida, e ao invés de cenas sociais como sugere o título, o romance está recheado de divagações e discursos que não apresentam objetivos dentro da narrativa. Curiosamente, este livro menciona também a história de amor de Abelardo e Heloísa. Contudo, no caso, a referência vem pela obra de Rousseau, La Nueva Heloísa. Além disso, diferente de Abelardo Manríquez, que sabe o livro de memória, o protagonista de Una escena social, fecha-o e maldiz o amor:

Todo es falso, dije un día, cerrando indignado un tomo de 'La Nueva Heloísa'. Detesto esas virtudes lagrimosas, tan recatadas en el sensualismo que llora sobre una falta cometida hasta encontrar de nuevo la ocasión de cometerla; y lleno de despecho contra el pacífico ciudadano de Ginebra, arrojé el libro hacia la extremidad opuesta de la mesa, y apoyé mi frente sobre la mano izquierda, actitud en la cual suelo quedarme largos instantes en meditación. ${ }^{44}$

Alfredo percorre um caminho oposto ao do calavera Abelardo Manríquez: enquanto o primeiro fecha o livro, o segundo o abre. Contudo, mesmo com essas diferenças, os dois seguem a mesma direção, já que o amor idealizado será a causa da morte de ambos. No seu primeiro romance, o autor não utiliza a representação da vida cotidiana para retratar as paixões humanas e as luzes iluminam, prioritariamente, o amor idealizado que tem seu desfecho com a morte da personagem. Situação completamente contrária se dá na narrativa do calavera, em que a morte é o ponto de partida para o desenvolvimento da trama e a busca pelo amor se torna muitas vezes secundária para dar passagem aos quadros cotidianos que privilegiam as aventuras cômicas do protagonista.

Por fim, a Advertência do livro El ideal de un Calavera é finalizada com o esclarecimento de que o romance diferencia-se de suas produções anteriores em alguns aspectos formais, pois exige certa variedade de peripécia que, no começo da segunda parte, é suspensa, o que pareceria prejudicar a unidade da obra. Mas, ao longo da terceira parte, as intrigas gerais da trama são conciliadas com ações que retomam e unem a primeira e a segunda parte.

\footnotetext{
${ }^{44}$ BLEST, Alberto, Gana. Bibliotecas de novelistas La Fascinación, Una Escena Social, La Aritmética en el amor. Zig-Zag: Santiago, s/d. p. 51.
} 


\section{2.- "A LAS ALMAS SENSIBLES..."}

A dedicatória da $3^{\text {a }}$ edição de El ideal de un Calavera dialoga diretamente com o romance, é uma espécie de pré-narrativa, na qual as temáticas do enredo estão indiretamente postas. Oferecendo pistas para o leitor num tom irônico, o autor esclarece, primeiramente, a quem o livro não está dedicado: “No está dedicado este libro á los hombres serios que hacen gala de menospreciar las letras, porque no alcanzan á comprenderlas”. ${ }^{45}$ (sic) Após a negativa, revela a que tipo de pessoa está dedicado o livro:

[...] á la almas generosas y sensibles”; “á los que persiguen afanosos una quimera forjada por la imaginación y desdeñan la modesta felicidad, que la suerte depara á los que con modestas cosas se contentan"; "á los que gustan de reir, como Fígaro, por no llorar de lo amarga que encierran las escenas cómicas de la vida.

$Y$ por fin, á los lectores, que con sinceras manifestaciones de simpatía, han alentado en sus tareas al autor de Martín Rivas. ${ }^{46}$ (sic)

Blest Gana não oferece ingenuamente o livro às almas generosas e sensíveis, pois há mais por trás dessa simples dedicatória. Embora também faça referência às mulheres, não se trata apenas de uma dedicatória àquelas que constituíam grande parte do público de leitores do século XIX e, geralmente, eram as mais atraídas por narrativas consideradas sentimentais. O autor evoca a imagem da figura romântica em sua essência, aqueles que perseguem sonhos e preferem o sofrimento ao contentamento de humildes consolações; os que obstinadamente perseguem uma quimera, assim como o protagonista Abelardo Manríquez, extraem da ficção, sobretudo, seus amores.

Esta ideia que parece ser o ponto de partida para armar uma narrativa romântica é manipulada em diversos momentos de acordo com a perspectiva do narrador, que ora a utiliza para convencer-nos do drama do protagonista, ora a nega para dar vazão a um suposto pensamento lógico e cientificista. Mas do que nos dizer sobre o protagonista, a dedicatória estabelece o tom paródico da narrativa.

\footnotetext{
${ }^{45}$ BLEST GANA. Op. Cit, TomoI, 1908. p. V.

${ }^{46}$ Ibid. Tomo I, 1908 p. VII.
} 
Reparemos que, além de dedicá-lo aos românticos, oferece o romance aos que gostam de rir como Fígaro. Esta menção ao cronista espanhol Mariano José de Larra (1809-1837), certamente, representa uma grande fonte de inspiração na composição da personagem de Abelardo Manríquez e dos outros calaveras presentes no romance. Larra escrevia artigos cômicos de costumes, assinando com o pseudônimo Fígaro. Entre seus artigos estão dois sobre os calaveras: Los calaveras - artículo primero e Los calaveras artículo segundo y conclusión. ${ }^{47}$. Esses dois artigos descrevem com detalhes a figura do calavera, separando-a por diferentes categorias que veremos mais adiante.

\section{3.- NARRAÇÃo: REALISMO E ARTIFÍCIO}

Iniciando o romance em média res, o narrador convocará os leitores sensíveis e os incluirá em seu discurso. A simpatia do narrador por Abelardo Manríquez dá-se antes mesmo da história ser contada: “Un sentimiento de profunda simpatía nos han inspirado siempre estas palabras que pronunció un joven en la más solemne circunstancia de su vida:"48

Na abertura, a dramática passagem dos minutos que antecedem ao fuzilamento do jovem, ganha um tom ainda mais comovente com verbos conjugados em primeira pessoa do plural, pois estes ampliam a voz do narrador e confundem-na com os referentes narrativos. Mantendo a tensão da cena, o narrador dá voz ao protagonista, que num remate romântico atira uma das mãos sobre a testa e com uma expressão melancólica diz: “-!Adiós, amor única ambición de mi alma!”49. Estes elementos do início da trama estão intencionalmente arranjados para envolver os leitores com a intrigante figura do calavera e para despertar também a curiosidade romanesca. Afinal, quais os motivos que teriam levado um belo jovem a despedir-se da vida com tão triste lamento?

\footnotetext{
${ }^{47}$ LARRA. José, Mariano. Los Calaveras. In: Artículos. Edición de Enrique Rubio. Madrid: Cátedra, 1987.

${ }^{48}$ BLEST, GANA. Op. Cit. Tomo I, 1908. p. 11.

${ }^{49}$ Ibid., p.11.
} 
Desenhando um círculo narrativo, El ideal de un calavera começa com a cena que concluirá no desfecho final. Envolvente, nessa primeira cena temos dois argumentos atrativos - o amor e a morte -, que juntos possuem as características de uma arte infalível $^{50}$. Haja vista que o leit motif amor mortal, lança-nos uma expectativa de uma grande história que por si só já garante o interesse inicial. Este efeito apelativo é realçado logo em seguida, quando o narrador repreende a malícia popular, que por anos empenhou-se em manchar a reputação do jovem. Diz o narrador que o vulgo que desconhece as razões do lamento de Abelardo Manríquez detém-se pouco a investigar as circunstâncias ${ }^{51}$. Julgam-no, continua ele, com ignorância e atribuem as palavras pronunciadas no patíbulo às suas ideias libertinas e imorais. No entanto, entre essa multidão, há vozes (estrategicamente indeterminadas) que se levantam em defesa dessa pobre alma, vítima de um destino fatal. Unindo-se em um escasso coro, perguntam pelos motivos de seu infortúnio:

$Y$ así repetíamos, uniéndonos á sus escasos defensores:

- ¡Pobre Manríquez!

¿No encerraba su exclamación postrera un adiós desesperado á las esperanzas desvanecidas?

¿Qué imagen de mujer huía en ese momento supremo del horizonte, que la febril imaginación de aquel joven iluminaba con sus fúlgidos resplandores?

¿Qué irresistible fuerza arrebataba el alma de ese condenado á muerte á la contemplación aterradora de los misterios del sepulcro, y le arrancaba, al morir, una imprecación de mundanales sentimientos? ${ }^{52}$

Nesse caminhar, o narrador nada ingênuo incorpora o recurso do coro utilizado nas tragédias clássicas para ampliar sua comunicação com os leitores. Nas peças da antiguidade, os coros desempenhavam funções narrativas, servindo como intermediários entre os atores e a plateia e expressavam a voz dos populares. Em Édipo Rei, por exemplo, o coro lamenta a situação da cidade. Já na trama de Blest Gana, a aparição do coro apoia-se em seu uso clássico, mas sem conceder a ele um papel narrativo, há neste trecho mais uma utilização para confirmar e afirmar a história contada, do que uma intervenção propriamente dita.

\footnotetext{
${ }^{50}$ ROUGEMONT, Denis. O amor e o Ocidente. Lisboa: Moraes Editores, 1968. p. 13.

${ }^{51}$ Essa referência a um jovem de fora do romance, de carne e osso, provoca um efeito intencional de superposição entre realidade e a ficção. Abelardo existiu realmente? Pergunta-se, o leitor.

${ }^{52}$ BLEST Gana. Op. Cit. Tomo I 1908. p, 13.
} 
Apesar de ser restrita somente a este momento, a presença do coro apresenta-se como uma solução bastante significativa, pois taticamente distingue e neutraliza a voz do narrador que aparecia tão marcada no primeiro parágrafo. Através desta função simbólica do coro, o narrador esconde-se e transforma-se em regente de uma harmoniosa orquestra de vozes. Tudo isso, para não conferir a si mesmo o excesso de sentimentalismo que logo adiante substituirá por uma postura investigativa que busca justificar socialmente a presença da temática do amor na obra: "El amor ocupa un espacio tan considerable en la historia de la humanidad, que siempre nos há parecido digna de estúdio la vida del pobre Manríquez, como un rasgo característico, que merece añadirse á la filosofia de esa historia." ${ }^{53}$ (sic)

Esse narrador cheio de artimanhas revela claramente as influências das correntes naturalistas que privilegiam o tema, mais pelo seu caráter patológico do que sentimental. Para fugir do excesso de apelo emocional e dar certo tom de veracidade à história, o narrador, que pretende fazer da vida de Abelardo Manríquez um estudo tomado da realidade, coloca-se também como testemunha ocular dos fatos: “Nosotros oímos repetir esas palabras en nuestra infancia y nos produjeron la impresión que dejan las palabras ó los hechos que la ignorancia de la niñez reviste con el ropaje prestigioso del misterio." 54 .

Um pouco à maneira dos naturalistas, o narrador demarca a vida do jovem como um objeto digno de estudo e a examina com lupas nas mãos. Com todo cuidado, ele tenta apagar o mistério que envolve a morte do jovem, a partir do segundo capítulo, entra na ordem da cronologia tradicional, da infância até a maturidade, realizando dessa maneira uma suposta observação empírica. Para dar maior autenticidade aos fatos, a exatidão da data, conforme nos diz Leo Bersani, é um elemento fundamental para o romance realista:

As datas são exatamente importantes na literatura realista, e o primeiro parágrafo de incontáveis romances do século XIX indica-nos o ano exato do início das historias. A precisão da data não serve unicamente à ilusão de autenticidade histórica; proporciona-nos igualmente o luxo de atribuir inícios precisos aos fatos vividos e, assim, torná-los mais acessíveis à nossa ânsia por categorias e distinções significativas. [.... $]^{55}$

\footnotetext{
${ }^{53}$ Ibid., p.13.

${ }^{54}$ Ibid,. p.12.

${ }^{55}$ Ver. BERSANI, Leo. O Realismo e o Medo do Desejo. In: Literatura e Realidade (o que é realismo?). Lisboa: Publicações Dom Quixote, 1984. p.55.
} 
O narrador apresenta-nos detalhadamente quais foram os vendavais que sopraram na vida do protagonista: “Abelardo Manríquez aumentó con una unidad, el millón de habitantes en que 1814 asignaban los geógrafos a la República de Chile, a principios de febrero.” Filho único de uma família empobrecida, Abelardo Marínquez teve uma infância correspondente ao padrão de sua época e classe social. Não possuía nenhum traço de genialidade, não era estudioso, mas se destacava na escola por comandar as travessuras. Entretanto, como observa Laura Hosiasson: "No se trata de una revisión determinista de la infancia en busca de causas y motivos que expliquen esa personalidad. Para probarlo, se nos dice que sus 'padres tenían una pasión sincera que el nacimiento de Abelardo vino a fortalecer'.," 56.

Descartando, por assim dizer, essa revisão determinista, podemos entender o fato de o autor ter detalhado tão cuidadosamente as aventuras de infância do jovem calavera, como um meio para introduzir, de maneira ambígua, a identificação que a personagem possui com seu famoso homônimo, Pierre Abelardo. Entre uma das inúmeras intromissões explicativas do narrador, ele nos conta que o pequeno Abelardo Manríquez: “Estudiaba poco; en cambio sabía de memoria las cartas de Eloísa y Abelardo, que han gozado siempre de una boga inmensa en todos los colegios” ${ }^{\text {57 }}$. Esta referência à Correspondência de Abelardo e Heloísa é fundamental para entendermos a relação de Abelardo Manríquez com a leitura das cartas e a composição de seu ideal.

\section{4. - CoRRESPONDÊNCIA dE AbELARDo \& Heloísa}

A tentativa de efetivar um entrelaçamento da Correspondência de Abelardo e Heloísa com o romance de Blest Gana implica num investimento teórico que necessita ser precedido e acompanhado por certos cuidados analíticos. Afinal, as especificidades temporais, culturais, religiosas e filosóficas que marcam o período da Idade Média também devem ser consideradas na composição desse mosaico.

\footnotetext{
${ }^{56}$ HOSIASSON, Laura J. “Blest Gana, Martín y el Calavera.” In: Revista de Literatura Chilena $\mathrm{n}^{\circ} 75$ noviembre de 2009, p. 5
} 
A história de Abelardo e Heloísa iniciou-se há quase um milênio, por volta do ano 1118, quando Heloísa tinha apenas 17 anos e Abelardo aproximadamente 38. O encontro dessas duas grandes figuras foi em palavras de Henry Adams, o acontecimento que aqueceu os termômetros da época: “O Século XII, apesar de seu brilho, seria apenas morno sem Abelardo e Heloísa". 58

Um drama real, a história do filósofo, teólogo e religioso francês Pierre Abelardo que se apaixona pela jovem Heloísa, uma mulher admirada, considerada à frente do seu tempo, tanto por estudiosos da atualidade como por seus contemporâneos. É impressionante o que diz o também monge amigo de Abelardo, Pedro, o Venerável, à Heloísa: “Quando o mundo inteiro oferece o triste espetáculo da mais deplorável apatia pelos estudos, e a sabedoria não sabe mais onde pôr os pés... tu te elevas acima de todas as mulheres e ultrapassas aos homens." 59

Heloísa viveu em Paris, na casa de seu tio Fulbert, cônego da catedral da cidade, que lhe deu uma educação invejável. Admiravelmente culta e inteligente, a jovem tornou-se aluna e amante de um dos mais célebres mestres de lógica e teologia da época, Pierre Abelardo. As aulas do famoso professor eram disputadíssimas, alunos vinham de todas as partes e se multiplicavam de maneira extraordinária: “chega[va] a reunir aproximadamente três mil ouvintes em torno de sua cátedra", ${ }^{60}$

A vida desse casal de amantes foi transformada em uma das mais belas histórias de amor, que por sua extraordinária trama, chega, em determinados momentos, a superar e confundir a imaginação criadora do ficcionista que respeita as leis da verossimilhança: "Pessoas que se tornam personagens; personagens que são pessoas reais; realidades que se transformam em mito; mitos que são realidades - tudo isso se pode dizer de Heloísa e Abelardo." ${ }^{61}$

Sob a história de amor pairam incertezas e ambiguidades que dividem os estudiosos sobre as possíveis classificações das cartas: alguns as tomam como documentos, outros como romance epistolar. Entretanto, todos concordam que a Correspondência não é apenas o "resultado puro e simples de uma colagem de cartas

\footnotetext{
${ }^{58}$ VILELA. PE. Orlando. O drama de Heloísa- Abelardo. Belo Horizonte: Editora Itatiaia Limitada, 1986. p.19.

${ }_{59}$ Venerabilis, P. Espitola ad Heloissan: ML, t. 189, col. 347. Apud VILELA. PE. Orlando. $O$ drama de Heloísa- Abelardo. Belo Horizonte: Editora Itatiaia Limitada. 1986. p 63. O trecho trata da primeira carta de Pedro o Venerável a Heloísa. Pedro que também era monge abrigou a Abelardo em seus últimos dias de vida.

${ }^{60}$ VILELA. PE. Orlando. OP. Cit, p. 56.

${ }^{61}$ Ibid., p. 51
} 
originais, mas sim um dossiê organizado: não certamente falso, mas uma 'obra', na medida em que essa palavra implica intenção e estruturação." ${ }^{62}$

Os manuscritos que constituem a Correspondência de Abelardo e Heloísa pertencem à biblioteca de Troyes; o primeiro da Historia Calamitatum ("Relato de minha Infelicidade”) é um texto autobiográfico, “escrito em forma de carta fictícia dirigida a um amigo anônimo, e cujo conteúdo implicaria que seja datada de 1132, quando Abelardo tinha cinquenta e três anos”63. As outras quatro partes que completam a obra são: uma Consolatio, enviada a Abelardo por Heloísa, depois que esta tomou conhecimento da carta enviada ao amigo de Abelardo; uma série de três cartas trocadas pelos amantes, três cartas de caráter impessoal, relativas à administração do Paracleto; e por fim, “uma Regra proposta por Abelardo às religiosas postas sob jurisdição de sua esposa" 64

Compiladas em fins do século XII, mais ou menos cento e cinquenta anos após os acontecimentos relatados, as cartas que compõem a Correspondência apresentam um grande lapso entre os acontecimentos e a organização da obra. Tal fato sinaliza para alguns medievalistas, uma suspeita sobre a autenticidade dos conteúdos da obra. Essa suspeita deu-se em meados do século XIX, quando as questões sobre a autoria, origens e finalidades da Correspondência passaram a ocupar os estudiosos conhecidos como “antiquários”. Até então, durante muito tempo, principalmente nos séculos XVI e XVII, “atribuíam a Abelardo a autoria do Roman de la Rose."65.

Cabe complementar que as dúvidas que obscurecem a autenticidade do conteúdo das cartas, não se dão puramente pela falta de regimentos autorais da época. Em razão dos conflitos de ordem política e religiosa, todos os estudos filosóficos de Abelardo foram incluídos na lista do Index. Nesse quadro, a dificuldade de acesso ao conjunto de sua obra, impediu que ela fosse lida na íntegra durante muito tempo. Nas palavras do medievalista José Carlos Estevão, professor da Faculdade de Filosofia da Universidade de São Paulo: “Abelardo, efetivamente não foi lido, mas tampouco esquecido. Sua memória é resgatada por Heloísa."66 Além disso, o pesquisador completa que: “a censura é relevante para nós, não porque tenha impedido a

\footnotetext{
${ }^{62}$ ZUMTHOR, Paul- ABELARDO, Pedro. 1079 -1142. Correspondência de Abelardo e Heloisa. São Paulo: Martins Fontes, 1989. p. 3.

${ }^{63}$ Ibid., p. 2.

${ }^{64}$ Ibid., p. 3.

${ }^{65}$ ESTÊVÃO, José Carlos. A Ética de Abelardo e o Indivíduo. Dissertação apresentada à Pontifícia Católica de São Paulo.PUC-SP. São Paulo 1990. p. 56.

${ }^{66}$ Ibid., p.47.
} 
circulação dos textos de Abelardo, mas porque determinou em parte, a ótica de muitas leituras futuras".

Conforme dito acima, as leituras da Correspondência não foram exatamente feitas com base em materiais originais ou completos, mas sim de modo clandestino. As cartas trocadas por Abelardo e Heloísa acabaram sofrendo também, no decorrer do tempo, apropriações, interpretações, retoques e re-significações. Esse fato responde por uma série de equívocos e confusões sobre a obra. Somente no fim do século XIII, com a tradução para o francês, feita por João de Meun, foi que a história de amor de Abelardo e Heloísa saiu dos círculos dos estudiosos das escolas parisienses da época para atingir outros públicos. Além de traduzir Correspondência, João de Meun também foi um dos primeiros responsáveis pela difusão das ideias de Heloísa sobre o matrimônio, tomando o casal como um modelo para a continuação de Le Roman de la Rose.

Ainda no que toca aos manuscritos da Correspondência, vale ressaltar que o manuscrito de número 2923 pertenceu a Petrarca (1304-1374), o poeta italiano, que se considerava um homem tão sofrido como Abelardo. Em uma das páginas em que Abelardo descreve seus momentos de solidão no Paracleto, Petrarca anotou ao lado a palavra solitudo. Embora não possuísse o mais conhecido dos manuscritos, o que constituiu a Correspondência de Abelardo e Heloísa, certamente o italiano teve acesso ao original, porque este pertenceu ao seu amigo, também italiano, Robertus de Bardis. Esses dados, além de nos darem uma ideia concreta de que os manuscritos da Correspondência estavam espalhados por várias partes da Europa, contribuem afirmativamente para comprovar as dificuldades de organização e estruturação dos originais, como também nos deixam pistas para compreender a importância e as influências que a história de Abelardo e Heloísa exerceu e ainda exerce sobre grandes escritores. Nessa direção, Paul Zumthor, contabiliza as influências da história de amor na literatura, de fins do século XVII até meados do século XIX:

[...] treze imitações mais ou menos livres em prosa, onze em verso, duas contrafações burlescas, ao que se podem acrescentar narrativas mais originais, como a que Rodolphe Teopffer inseriu em suas Nouvelles genovoises; Rousseau não deu por acaso o título de Nouvelle Héloïse ao livro que conhecemos, e dois romances um pouco posteriores que versam sobre o tema, um anônimo, outro de Restif de la Bretonne, Le Nouvel Abailard (1778-1779); em nossos dias ainda, essa tradição subiste: da peça de Roger Vaillant ao 
romance que eu mesmo publiquei pela Gallimard em 1969, Le Puits Babel... ${ }^{67}$

Ao lado das aproximadamente 33 obras contabilizadas por Paul Zumthor, podem-se acrescentar outras tantas. Mesmo o realista francês, Balzac, chegou esboçar um pequeno texto sobre Abelardo. Em uma carta à Condessa Hanska, ele comentou o seu desejo de incluir na Comédia Humana ${ }^{68}$ um romance baseado na história dos amantes; o espaço para este romance está marcado apenas com o título Le nouvel Abelard e umas poucas linhas que informam que por alguma razão desconhecida o autor abandonou o projeto.

Mesmo tratando-se de um drama real, a escrita das epístolas que posteriormente se denominaram Correspondência de Abelardo e Heloísa, não deve ser analisada apenas como um documento de cartas amorosas. Isto porque já na primeira carta, Historia Clamitatum, Abelardo expressa claramente suas pretensões de não só revisar o caminho que percorreu para instalar-se na cátedra parisiense, mas também suas intenções de explicar, através de suas memórias, as injúrias e mal-entendidos que difamaram sua imagem. Afirma logo no início que "às vezes é mais fácil tocar o coração de alguém pelo exemplo do que pelo discurso.”69 Nessa direção, é necessário ressaltar que as reminiscências de Abelardo funcionam, de certo modo, como uma revisão de vida que coloca em evidência as penitências para buscar a absolvição. Assim como o Abelardo Marínquez, muitos leitores inadvertidos mergulham na leitura da Correspondência, desconhecendo as possíveis intenções de Pierre Abelardo.

No discurso que assume a forma de exemplo, o abade francês relata minuciosamente os percalços de sua vida: a inveja de seu mestre Guillaume de Champeaux; os ciúmes de seus condiscípulos do curso de exegese; seu destaque nos estudos, tanto filosóficos quanto teológicos; as censuras; sua entrada na vida religiosa; as calúnias; as perseguições de São Bernardo. E, entrelaçada a todos esses acontecimentos, a fascinante história do seu amor com Heloísa.

Também temos que considerar que sobre as cartas trocadas com Heloísa, o próprio Pierre Abelardo declara que: “as palavras que se escrevem muitas vezes são

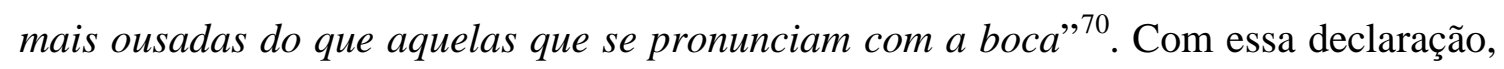

\footnotetext{
${ }^{67}$ ZUMTHOR, Paul. Op. Cit, p. 5.

${ }^{68}$ Edição francesa, La comédie Humaine- éditions du seui Paris Galliard. 1996.

${ }^{69}$ ZUMTHOR, Paul. Op. Cit, p.29.

${ }^{70}$ Ibid., p. 40.
} 
estabelece, por um lado, uma distorção entre as cartas e os acontecimentos reais, para dessa forma defender-se de algum modo, do pecado carnal. Por outro lado, dá-nos através do mesmo efeito de separação entre a escrita e a realidade, a relação ambivalente das cartas pessoais que trazem a público aquilo que é privado. Processo este que envolve a re-organização e estruturação dos fatos. Sendo assim, cabe a nós refletir se o amor de Heloísa e Abelardo é uma fascinante história ou uma história contada de forma fascinante.

Deixemos um pouco de lado essas reflexões sobre as intenções e reordenações das cartas para nos aproximar da narrativa da Correspondência de Abelardo e Heloísa, e, com este auxílio, compreender a relação intertextual que o autor chileno estabelece entre esta obra e o ideal de amor do protagonista Abelardo Manríquez.

Pierre Abelardo, procurando travar uma relação mais próxima e cotidiana com Heloísa, propôs ao cônego Fulbert, tio da jovem, que o recebesse como pensionista em sua casa. A prática de alugar quartos para professores e estudantes era bastante comum nesse período, e além de cumprir o papel de aproximá-lo de Heloísa, também lhe seria conveniente, pois a escola em que lecionava ficava a poucas quadras da casa de Fulbert. Como parte do pagamento, Abelardo ofereceu-se para dar aulas particulares a Heloísa. A proposta foi logo aceita pelo cônego que ambicionava que a sobrinha prosseguisse com os estudos.

No seu relato, Pierre Abelardo nos conta que foi durante as aulas que seduziu a Heloísa, o estudo era apenas um pretexto para consumar o amor. Os frequentes encontros com a jovem provocaram rumores entre os alunos que se queixavam da dispersão do mestre. Com tantos comentários, não demorou muito para que o tio de Heloísa descobrisse o que de fato acontecia. Os amantes foram obrigados a se separarem, mas uma noite aproveitando-se da ausência do tio, Abelardo raptou Heloísa e grávida a levou para Bretanha, onde ela permaneceu até o dia em que deu à luz a uma criança que chamou de Astrolábio.

Fulbert quase enlouqueceu quando ficou sabendo da fuga. A desonra de sua sobrinha levou o cônego a planejar os mais frios desejos de vingança. Abelardo, sabendo da aflição do ancião, prometeu-lhe desposar aquela que havia seduzido. No entanto, o noivo pediu que o casamento fosse mantido em segredo para não prejudicar sua reputação de filósofo. Em princípio, o tio consentiu a exigência, e Heloísa, mesmo não concordando com o casamento, retornou a Paris, onde os dois casaram-se, mas como a união era secreta, no dia seguinte, voltaram a se separar. Depois de muitos 
boatos sobre o casamento, Abelardo enviou Heloísa para a abadia de religiosas reclusas, em Argenteuil.

Transtornado com a manobra que reparava secretamente a vergonha que havia sido pública, Fulbert armou uma vingança contra o esposo da sobrinha. Certa noite, após subornar um dos servidores de Abelardo, enviou alguns homens ao quarto do filósofo quando esse ainda dormia e o fez sofrer uma das mais cruentas e vergonhosas vinganças. Nas palavras de Abelardo: “amputaram-me as partes do corpo com as quais eu cometera o delito de que se queixavam." 71

A mutilação separou fisicamente os amantes. Heloísa lamentou profundamente a ferida que o casamento lançou sobre a sua sorte. Sem vocação para a vida monástica, vestiu o hábito, mas não o véu. É atribuído a ela o provérbio que diz que “o hábito não faz o monge”. Foi por amor a Abelardo e não a Cristo, que ela aceitou tomar o véu. No mesmo dia, Abelardo e Heloísa pronunciavam os votos religiosos de castidade, ele em Saint-Denys e ela em Argenteuil.

Após a conversão, eles se viram apenas algumas vezes, mas continuaram comunicando-se através de cartas. Abelardo faleceu com sessenta e três anos e foi enterrado no Paracleto, o convento que ele mesmo fundara. Heloísa morreu alguns anos depois, e seu último desejo foi unir-se na morte àquele do qual as circunstâncias da vida a haviam separado. Pediu para ser enterrada no mesmo caixão de Abelardo.

\section{5.- CORRESPONDÊNCIA DE ABELARDo \& INÉS}

As passagens expostas sobre a história de Abelardo e Heloísa nos interessam bastante, porque no romance de Blest Gana, temos ocorrências mais ou menos parecidas. O protagonista homônimo, Abelardo Manríquez, fica hospedado na casa de sua amada, Inês Arboleda, mas à diferença do planejamento de Pierre Abelardo, a permanência na casa dá-se mais pelas circunstâncias do que por sua meticulosidade. Este acontecimento ocorre na primeira parte do romance que é intitulada Cenas del Campo. Pelas informações fornecidas pelo narrador, não sabemos ao certo o nome da cidade, mas por alguns comentários podemos inferir que ela não fica muito longe de

\footnotetext{
${ }^{71}$ ZUMTHOR, Paul.Op. Cit, p. 50.
} 
Santiago. Dentro deste quadro campestre, o narrador articula a recorrente oposição entre campo e cidade, dando ao primeiro um aspecto grosseiro e ao segundo os requintes da sofisticação.

O período de permanência de Abelardo Manríquez na casa dos Arboledas é, entre as diversas passagens, o momento mais caricatural do antagonismo entre a barbárie e a civilização, pois há nele um contraste entre a medicina e as práticas de cura utilizadas no campo, que ironicamente o narrador chama de ciências do campo. O ensejo para marcar as diferenças é o acidente que Abelardo Manríquez sofre no rodeio da região. O incidente se dá após ele realizar uma difícil manobra com o cavalo, para impressionar Inés. Levado inconsciente à casa da amada é entregue aos cuidados de um rudimentar “Aliñador” que segundo o narrador: “es el cirujano prático del lugar, que usa de los mismos métodos para curar á sus semejantes, que los que emplea en su práctica veterinária"72. O 'aliñador' é ajudado por uma “médica milagrosa”, ña Margarita, que pelo adjetivo como é conhecida e pela redução da forma de tratamento de dueña para ña -, percebemos que não se trata exatamente de uma médica, sendo mais reconhecida pelos supersticiosos meios de cura do que por seus métodos científicos.

Quando recobra a consciência e a saúde, o ardiloso Abelardo Manríquez continua fingindo a enfermidade para prolongar sua estadia na casa e, da mesma forma que Pierre Abelardo, tenta estabelecer no ambiente doméstico uma relação mais próxima com Inés. Sem muitas dificuldades, desvenda as práticas nada científicas da médica feiticeira, ña Margarita. Manríquez chantageia-a dizendo que se ela não o obedecer em tudo, irá enviá-la para a prisão, acusando-a de charlatã. Suas ordens consistem em que ela prossiga com a farsa da doença e sirva também de intermediária para que ele possa estabelecer uma comunicação com Inés, por meio do envio de correspondência.

A relação intertextual do episódio de Abelardo Manríquez com o relato de Pierre Abelardo pode ser mais facilmente percebida por oposição do que por aproximação. Caracteriza-se pela inversão que nos dá um valor negativo onde havia uma marca de valor positivo. Ou seja, um empenho que visa de uma só vez, afirmar, negar e pôr em outro plano. Nessa medida, estamos diante de um jogo intertextual que se estrutura não exatamente pelo enquadramento dos traços, mas sim pelo encaixe disforme que realça as sobras e as faltas. Como se fosse uma fôrma que ora se expande

\footnotetext{
${ }^{72}$ BLEST, Gana. Op. Cit, 1908.Tomo I, p.105.
} 
ao calor do fogo, ora se retrai ao contato com o gelo, as referências às cartas estão articuladas por aproximações e rupturas dos aspectos originais. É através desses bruscos e sutis movimentos que se estabelece o romance de Blest Gana. As implicações dessas reviravoltas serão discutidas ao longo de todo o trabalho.

No plano das motivações das protagonistas femininas das duas obras, os sentimentos de Inés Arboleda por Abelardo Manríquez em muito se diferenciam do amor da Heloísa do século XII. Ao receber a carta de Manríquez, Inés é tomada por uma súbita emoção, pois se trata de sua primeira carta de amor. As palavras escritas naquelas linhas, a sonoridade, o ritmo, tudo está ali arranjado para homenagear sua beleza. O narrador, em suas constantes interpolações, observa ironicamente que o entusiasmo da jovem não significa que Abelardo Manríquez seja correspondido, já que pensar assim seria "manifestar uma profunda ignorancia de la fisiologia moral, y sobre todo, de la del corazón de la mujer."73

Inés é a primeira mulher com a qual Abelardo Manríquez pensa ser capaz de realizar seu ideal, amou-a desde a "primera mirada”: Quando a vê pela primeira vez, já guardava tantas expectativas sobre sua beleza, que no mesmo instante consagra-lhe sua vida. No entanto, a pressa por acalmar o coração que busca desesperadamente as emoções do amor, cega-o completamente e o calavera apaixona-se pelas formas de uma imagem distorcida:

Manríquez fijó con avidez la vista en la que quedó sentada Era sin duda la que su vecino había dicho ser bonita. Rubios cabellos, La finísima tez, ojos grandes, boca pequeña, rosada y fresca como una cereza, manos largas y delgadas, un talle fino, de suaves contornos, el seno modestamente dibujado por el vestido de percal, he aquí lo que Abelardo alcanzó á ver. Como la joven había bajado la vista sobre la costura, la expresión de su rostro, esa irradiación del alma en las facciones, se escapaba en aquel momento á su observación. ${ }^{74}$

A primeira aparição de Inés Arboleda na narrativa obedece, como podemos reparar no trecho acima citado, aos procedimentos típicos das descrições de apresentações das personagens nos romances romântico-realistas. Se lermos atentamente, perceberemos que essas poucas palavras guardam uma preciosa informação sobre as características que constituem o caráter de Inés, e consequentemente, já revelam a razão do engano de Abelardo Manríquez. Observa-se

\footnotetext{
${ }^{73}$ BLEST, Gana. Op. Cit. Tomo I, 1908. p. 124.

${ }^{74}$ Ibid., p. 30.
} 
que Inés abaixa o rosto sobre a costura antes que o olhar de seu admirador possa cruzar com o dela. O desvio do olhar não permite que o protagonista encontre no rosto de sua futura amada o que o narrador nomeia de expressão da alma. Por conta dessa leve e aparentemente tímida movimentação, escapa ao jovem notar a verdadeira face de Inés, que ele só irá descobrir posteriormente.

A descoberta de Abelardo Manríquez sobre o verdadeiro caráter de Inés Arboleda, que acontece muito depois na narrativa, seria uma espécie de reconhecimento “anagnórisis”, acontecimento que nas tragédias clássicas representa a tomada de consciência por parte do herói de um erro que ele mesmo cometeu no passado. O momento do reconhecimento se dá na peripécia que encerra a primeira parte da obra, quando o protagonista tenta raptar a amada, mas descobre que ela o despreza. A partir desta passagem, Abelardo Manríquez começa a enxergar Inés Arboleda da forma que o narrador havia descrito desde o começo, e reconhece que no coração dela há antes a vaidade de ser amada do que realmente amor.

Um tanto quanto peculiar, o dito reconhecimento é uma descoberta apenas do protagonista, pois antes mesmo desse episódio, o narrador, que possui o absoluto domínio sobre os pensamentos das personagens, conta-nos sobre o coquetismo de Inés, o que junto com os aspectos da sugerida intertextualidade com a Correspondência de Abelardo e Heloísa retira, de certa forma, um pouco da carga trágica que aqui aparece revestida com humor.

Nesse sentido, uma das passagens mais expressivas é quando nos são contadas as impressões de Inés ao receber as cartas de Abelardo Manríquez. A princípio, ela fica indecisa se deveria ou não responder, contudo, duas razões a fazem escrever: a primeira, o medo das ameaças de Abelardo Manríquez, pois sabe que, diante de seu silêncio, ele poderia cometer uma imprudência e comprometê-la; a segunda, não menos importante, é a vaidade, pois prefere correr o risco da aventura a perder um adorador tão interessante.

A admirável inteligência de Heloísa também é contrastada pela figura de Inés. A transgressão dá-se novamente pela forma irônica com que o narrador nos faz conhecer a inabilidade da jovem para responder a carta. Temendo demonstrar sua falta de cultura e seus erros ortográficos em uma carta mal redigida, ela inventa um engenhoso método para evitar que suas respostas a comprometessem, mais pelas falhas gramaticais do que por sua reputação. Com muita paciência, Inés consulta os livros da 
biblioteca de sua casa e retira deles palavras para compor sua redação, deste modo tenta esconder a falta de habilidade para escrita:

Esta fuerza de voluntad la sugirió la idea de vencer los escollos ortográficos á costa de paciencia, y con tal fin decidió no emplear en caso de duda, más que palabras sacadas de algún libro. La biblioteca de las casas del Trébol consistía sólo en algunos libros devotos, usados por Andrea y por su madre. En ellos fuéle preciso á Inés buscar las palabras para escribir, según su ingenioso método. Por fin, al cabo de cuatro borradores, llegó á poner en limpio esta carta, en contestación á las de Manríquez:

'Yo también me alegro de que usted esté alojado en casa, porque así podremos serle útiles en algo. Su estado nos ha tenido en una grande inquietud, y deseamos mucho que se mejore. Por mi parte lo deseo también, no por verlo alejarse de aquí, sino porque es natural me interese por la salud de un amigo á quien aprecio. En cuanto á lo demás que me dice en su carta, le responderé, como antes no le creo' $(\operatorname{sic})^{75}$

O momento de troca das cartas representa um ponto alto para o diálogo do romance de Blest Gana com a Correspondência de Abelardo e Heloísa, já que percebemos, através dos problemas de escrita de Inés, o contraste com a erudição de Heloísa. Também podemos notar, nas cartas de Abelardo Manríquez a Inés Arboleda, que a identificação do jovem com Pierre Abelardo dá-se de maneira invertida. Ou seja, que não se trata de uma identificação total, como a do Quixote com os heróis de cavalaria. Abelardo Manríquez não deseja em momento algum seguir os passos de Pierre Abelardo. Pelo contrário, os feitos da carreira do religioso e educador nada significam para ele e a atração é tão somente sobre os sentimentos que Pierre Abelardo desperta em Heloísa.

Conforme nos diz o filósofo Padre Orlando Vilela: “É que, se Abelardo- como filósofo, dialético e teólogo - é superior a Heloísa no drama ela - “vale pelo menos uma dúzia de Abelardos”. ${ }^{76}$. Sem dúvida, através da leitura da Correspondência, Heloísa é superior a Abelardo, e para nós é importante frisar que foi por essa via que o protagonista conheceu a história de seu homônimo.

Um amor igual ao de Heloísa é o que Abelardo Manríquez busca em Inés. Um amor puro, profundo, desinteressado e capaz de realizar-se em si mesmo. Em uma passagem posterior, retirada da conversa do calavera com seu amigo Felipe Solama, o

\footnotetext{
${ }^{75}$ BLEST, Gana. Op. Cit, Tomo I, 1908. pp.126-127.

${ }^{76}$ VILELA, PE. Orlando. Op. Cit, p. 18.
} 
protagonista se detém a confidenciar como nasceu seu ideal, ou melhor, como ele próprio intitula: “la introducción a mi ideal”:

[...] empecé a nutrir mis esperanzas con los caprichos de la imaginación: ellos me trajeron un día, tras ansias locas, el tipo de mujer que ambicionaba mi pecho, haciendo resonar en mi memoria los nombres de Safo y Eloísa. ¡Mira, me puse alegre como si hubiese hecho un gran descubrimiento con esas enamoradas sublimes! ¿Qué otra cosa ambicionaba yo en efecto, sino la pasión fogosa y desinteresada, la adoración delirante, el completo desprecio de las convenciones sociales en la mujer que me amase? Enamorado de la forma precisa que mis deseos infinitos tomaban con la evocación de esos dos nombres mágicos, estudié la vida de las que habían llevado, participé de sus cuitas y busqué en la fuente que incendiaba su sangre el encantado filtro de amor que viene rejuveneciendo al alma humana desde la creación [...]:"77

Neste trecho, o narrador confere a Manríquez a possibilidade de ele nos dar suas próprias 'explicações' sobre seu ideal, recurso narrativo que, segundo Laura Hosiasson, ${ }^{78}$ parece nos indicar uma espécie de fracasso na tentativa do narrador de compreender seu protagonista. Tomando a voz narrativa, o próprio Abelardo Manríquez nos explica que em princípio a busca por seu ideal baseava-se em duas figuras femininas: Safo e Heloísa. Ele estudou cuidadosamente a maneira como elas se dedicaram a seus amados, e com o mesmo cuidado como se desprenderam das convenções sociais em nome do amor. Encantado com essas histórias idealizou ser amado por uma mulher, que como suas “musas," fosse capaz de renunciar à ambição e ao egoísmo cultivado pelas mulheres da atualidade. Seu desejo é viver intensamente a sensação de um amor tão sublime como os das histórias que leu, esperando que o amor e a entrega sejam exatamente iguais. Por isso, durante algum tempo, foi Faón e foi Abelardo, mas uma inexplicável predileção fez com que escolhesse a abadessa ao invés da poetiza. Acreditamos que tal predileção traga em seu bojo uma intencionalidade estrutural mais romântica, isso porque a imagem de Safo apresenta-se menos romantizada do que a de Heloísa.

Ao desejar um amor como o de Heloísa, o protagonista não se dá conta da inversão de seus sentimentos, ou seja, que ele se aproxima mais da figura da amada do

\footnotetext{
${ }^{77}$ BLEST, Gana. Op. Cit. Tomo I, 1908. pp 52-53. (grifos nossos)

${ }^{78}$ HOSIASSON, Laura. Op.cit, 2009.
} 
que do amor idealizado. Facilmente podemos perceber que em muitas oportunidades, Abelardo Manríquez não ocupa o lugar de Pierre Abelardo, mas sim o de Heloísa. Seus sentimentos se encaixam perfeitamente no que René Girad ${ }^{79}$ chama de desejo triangular. Derivado e imitativo, o esquema do triângulo representa a existência de um elemento mediador entre o sujeito que deseja e o objeto do desejo.

Ambivalente, o elemento mediador é, ao mesmo tempo, o desencadeador do desejo e o sujeito que deseja. Sendo assim, este elemento encontra-se mais presente em quem deseja do que no objeto desejado, o que equivaleria a pensar que Abelardo Manríquez passa a ser menos o sujeito que deseja o amor de sua musa e mais ela mesma.

Comparando as cartas de Heloísa, em resposta às de Pierre Abelardo, com as enviadas por Abelardo Manríquez a Inês podemos perceber melhor essa inversão. Na primeira carta que o calavera escreve à jovem, ele diz: “la amo más que á mi vida. Esta no tiene precio alguno para mí sin Vd”. ${ }^{80}$ Enquanto Heloísa escreve a Pierre Abelardo: "Mas que me resta esperar, agora que te perdi? De que adianta prosseguir essa jornada terrestre em que eras meu único apoio? Em minha última alegria, desde que todas as outras me foram proibidas, era te saber vivo?" ${ }^{81}$. Também coincidem os inúmeros pedidos de consolo que só a presença do amado poderia trazer.

Assim como o amor de Heloísa por Pierre Abelardo, o de Abelardo Manríquez por Inés é constituído por sentimentos submissos, que demonstram uma adoração elevada a graus extremos, em que a própria vida é menos valiosa que os sentimentos. A partir desses elementos, percebemos que a transposição do modelo de amor idealizado pelo calavera não guia somente uma busca externa. Completamente envolvido pela leitura da Correspondência, ele idealiza a forma como deseja ser amado, mas do que ele não se dá conta é que também ama Inés com a mesma servidão com a qual Heloísa amou Abelardo.

Mais uma vez, recorrendo às cartas enviadas por Abelardo Manríquez a Inés, destacamos pequenas passagens selecionadas na sétima e na oitava missivas ${ }^{82}$ para sinalizar a recorrência da tópica do obstáculo imposto aos amantes. Sétima carta:

\footnotetext{
${ }^{79}$ GIRARD, René. Deceit Desire and the Novel: Self and Other in Literatury Structure. Trad. Yvonne Freccero. Baltimore, Johns Hopkins UP, 1965 apud DIXON Paul. O Chocalho de Brás Cubas- Uma leitura de Memórias Póstumas. São Paulo: Edusp/ Nanquin, 2009. p. 100.

${ }^{80}$ BLEST, Gana. Op. Cit. Tomo I 1908. p.122.

${ }^{81}$ Ibid., p. 113.

${ }^{82}$ Numeração proposta por mim a partir da ordem que aparece na narrativa apenas com a intenção de facilitar a localização.
} 
"Disponga Vd. de mí. La tiranía de los padres sólo puede triunfar de los corazones débiles y el suyo debe ser fuerte". ${ }^{83}$; Oitava carta: [...] dígame que la han obligado á obedecer. [...] dígame que ha obedecido, y todo lo olvidaré, menos mi amor, que vivirá en mi pecho eternamente. ${ }^{84}$. Ele escreve estas cartas após escutar, dos empregados da casa, rumores e especulações sobre o pedido da mão de Inés pelo seu rico adversário, Miguel de Sendero. Conhecendo a preferência que os pais da jovem manifestam pelo endinheirado rival, Abelardo Manríquez acaba sendo tomado por devaneios apaixonados, e pensa que se trata de um obstáculo comumente presente na vida de grandes amantes. Negando a realidade, acredita que Inés está sendo vítima da autoridade paterna e somente ele poderá salvá-la.

Sentimentos de entrega submissa e a existência de obstáculos são as mais recorrentes tópicas do amor cortês ${ }^{85}$. Não se sabe ao certo onde e quando exatamente surgiram as primeiras premissas e manifestações desse tipo particular de relação amorosa. Atribui-se sua origem a algumas linhagens nobres, especialmente no Oeste e Sudoeste da França, que não tardou a se difundir por todo o reino, e depois por todo Ocidente Cristão. ${ }^{86}$. Completamente à margem da tão representativa moralidade eclesiástica do mundo medieval cristão, o amor cortês simboliza a secularização do amor. O amor carnal, que era desde então reprovado pela Igreja, passa de sentimentos profanos a sentimentos elevados. Em princípio, restrito ao ambiente das cortes feudais, a nova concepção de afeto entre homem e mulher (geralmente em relações extraconjugais) ganhava outra instância.

A invenção do casal amoroso reporta-se aos séculos XI e XII, período em que se pode estabelecer com melhor precisão a florescente mudança. Ultrapassando as cortes feudais, o amor cortês passa a assumir um papel representativo e comum no ideário das outras camadas sociais. Esse novo sentimento que atravessou o ideário coletivo remontou o exclusivismo das narrativas épicas para abrir frente aos cantos e cantigas sentimentais. Sendo importante ressaltar que a representação do trovador não está expressa unicamente por seus sentimentos, há sempre uma adoção de tópicas distantes do subjetivismo romântico. A voz de quem evoca o desejo vem subscrita à

\footnotetext{
${ }^{83}$ Ibid., p. 134-135.

${ }^{84}$ Ibid., p. 140.

${ }^{85}$ ORTEGA, José, y Gasset. "Notas sobre o amor cortês”. In: Estudos sobre o amor.. Tradução e Prólogo Luis Washington Vita. Rio de Janeiro: Livro Ibero-Americano LTDA, 1960.

${ }^{86}$ ZUMTHOR, Paul. Op. Cit. p. 8.
} 
apropriação de um ethos: “o amor cortês” vacila sempre entre o real e uma ficção simbólica. ${ }^{87}$

Nesse quadro, para nossa análise, interessa-nos lembrar que tudo isso foi vivido intensamente pelo nosso conhecido casal de amantes, Abelardo e Heloísa e, sobretudo, convida-nos a pensar que tipo de influências as tópicas trovadorescas poderiam ter exercido sobre a escrita das cartas que constituem a Correspondência. Embora a história dos amantes do século XII seja real, é possível constatar que as epístolas foram mais estruturadas por uma forma de representar os sentimentos do que pelo amor que realmente sentiam. Estas relações complexas e menos subjetivas certamente passam despercebidas por Abelardo Manríquez, um leitor do século XIX que realiza uma leitura completamente romantizada. Em seu próprio relato sobre a leitura da Correspondência diz: Las llamaradas de un amor que arrojó en sus cartas, fiel trasunto de su inmensa pasión, produjeron en mi espíritu un delirio que las realidades de la vida no bastan a disipar. Naturalmente, quise buscar á mi Eloísa en el mundo ${ }^{88}$. Vê-se daí que há uma intermediação da leitura que foi re-significada por outros textos durante os séculos e todo este caminho influenciará a idealização amorosa do nosso calavera.

Dito isto, retornemos ao triângulo amoroso do romance de Blest Gana, Abelardo Manríquez, Inés Arboleda e Juan Miguel de Sendero, para analisá-lo com mais cuidado em todos seus ângulos. Assimétrico, este triângulo não é equilátero, mas sim um triângulo escaleno, cujos três lados são desiguais. O rival, Juan Miguel de Sendero, não possui a beleza de Abelardo Manríquez, nem quanto ao caráter físico nem quanto ao moral, mas a seu favor tem a ascendência pecuniária, pois é filho de um abastado comerciante de Santiago, atributo suficiente para Inés que pensaba antes en el matrimonio que en el amor" 89.

No entanto, Manríquez, acreditando ser mais bem qualificado para ocupar o lugar de amante no coração de Inés, persiste na conquista e disputa com Sendero pelo amor da jovem à moda de outro gênero, o cavalheiresco. Muito diferente do amor cortês, o amor cavalheiresco é mais espiritual e não necessariamente necessita ser concretizado, enquanto o cortês é mais carnal. A variante principal é a forma de pensar a figura feminina, já que no amor cavalheiresco, a mulher é vista de forma bastante passiva. A donzela é a representação da falta de ação da mulher que sempre espera as

\footnotetext{
${ }^{87}$ ORTEGA Op. Cit. p. 179.

${ }^{88}$ BLEST, Gana. Op. Cit. 1908. Tomo I, pp 52-53. (*grifos nossos)

${ }^{89}$ BLEST, Gana. Op. Cit 1908. Tomo I,p. 66.
} 
iniciativas dos outros e apresenta-se inferior ao homem. Já no amor cortês, a mulher tem direito a voz e é elevada a uma posição superior à do homem.

Na narrativa de Blest Gana, as imagens do amor cavalheiresco se recobrem de humor. Durante a apresentação do rodeio, Manríquez e Sendero disputam os olhares de Inés, olhares estes que ela, sabiamente, reparte sem que os seus pretendentes percebam sua divisão. Sendero comenta com desdém a arriscada manobra do peão que a plateia aplaude com entusiasmo. Inés, experimentando a agradável sensação de ser bajulada, ironiza as palavras de Sendero, e pergunta-lhe:¿Se animaría usted á hacer otro tanto? ${ }^{90}$

A estampa de donzela não cabe em Inés. Parodicamente ela manipula seus admiradores e praticamente os induz ao duelo. Na verdade, será ela quem habilmente desafia Sendero. A suposta donzela não resiste à tentação de ver seus dois pretendentes disputarem seu coração. No duelo, como em qualquer romance cavalheiresco, o oponente é humilhado, enquanto o cavaleiro brilha honrosamente aos olhos da plateia e da donzela. Vale a pena acompanhar a forma como o narrador parodia os romances cavalheirescos, utilizando de forma cômica os vocábulos do gênero para ressaltar a superioridade de Abelardo Manríquez:

Manríquez llegó, entretanto, al punto en que se hacía la aparta. Brillaban de juvenil ardor sus ojos animados, y sentía en el pecho la petulante impaciencia del que aspira á conquistarse en todas partes la admiración de los demás. Al internarse entre los animales vacunos, en medio de los cuales había sido preciso sacar á Juan Miguel Sendero, Abelardo iba con la decisión con que los paladines de la edad media entraban en la arena de un torneo bajo la mirada alentadora de sus damas: la presencia de Inés redoblaba los bríos naturales de su pecho amante del peligro. ${ }^{91}$

O acidente que leva Abelardo Manríquez à casa de Inés dá-se momentos depois, mas de modo algum apaga para o narrador a glória de suas manobras. Nessa ocasião, Inés, tão envolvida nos elogios da fantasia de donzela, esquece por um instante sua condição de coquete e se sensibiliza quase que apaixonadamente pelo pretendente desfalecido:

Esas voces produjeron en el alma de Inés otra sensación que la de espanto que infunde la noticia ó la vista de una catástrofe: parecióle que con la muerte de Manríquez se apagaba en su pecho la clara llama de una esperanza dorada. Púsose muy pálida y sintió que

\footnotetext{
${ }^{90}$ Ibid., p. 51

${ }^{91}$ Ibid., p. 96.
} 
involuntarias lagrimas humedecían sus párpados. Se le figuró que se nublaba el sol y que los alegres paisajes del contorno se revestían de duelo. ${ }^{92}$

Mas esse momento de 'fraqueza' sentimental logo irá desaparecer e Inés volta à normalidade do seu comportamento de coquete burguesa do século XIX. O coração de Inés prefere antes a riqueza de Juan Miguel Sendero aos sentimentos do jovem sem dinheiro, Abelardo Manríquez. Nessa direção, os comportamentos esperados se distanciam dos prescritos na Correspondênica. Tal descompasso do movimento da narrativa representa uma transgressão da história de Abelardo e Heloísa, que subverte a relação dos amantes e do amor. Sendo assim, temos no lugar do eclesiástico, o calavera e no lugar de Heloísa, a fria e sedutora, Inés Arboleda, e ao invés do amor, uma ideia fixa. A secularização materialista do século XIX impõe-se sobre o idealismo medieval do século XII.

\section{5.- LEITORES DA FiCÇÃo - LEITURAS “FiCCIONALIZADAS”}

Em seu belo trabalho, La dorada garra de la lectura, Susana Zanetti traça duas formas de representação do ato de leitura nos romances latino-americanos. Uma que se apresenta principalmente nos primeiros romances, nos quais a presença da leitura obedece a uma função tópica destinada, ao mesmo tempo, a introduzir um quadro de costumes e incentivar o hábito da leitura. E outra que estabelece uma relação estética e ideológica entre a obra lida e a trama, de maneira que as leituras realizadas pelas personagens acabam por confeccionar suas personalidades. Se a primeira forma intenciona promover a leitura, mostrando-a como um costume habitual dos cidadãos de determinada classe social ou nível cultural, a segunda não é diferente, já que as pretensões de estimular a leitura também estão presentes; entretanto, há uma postura mais crítica, que não só traz os leitores para a ficção, mas também ficcionaliza as leituras.

Nesta segunda forma insere-se a obra de Blest Gana. Desde seu primeiro romance, Una Escena Social, o protagonista Alfredo é um leitor extensivo, lê tanto

\footnotetext{
${ }^{92}$ Ibid., p. 99.
} 
livros de ficção como de história e filosofia. Rousseau, Plutarco, Robespierre, Lord Byron, Fígaro, Platão, Fray Luis de Léon, Hoffmann são alguns dos escritores que a personagem comenta nas quatro primeiras páginas do romance. Alfredo é um homem culto, no entanto, mais importante do que demonstrar sua erudição, através das citações de suas leituras, está o desempenho que elas apresentam na trama, pois não estão aleatoriamente postas, e Alfredo é uma personagem romântica porque as suas leituras o constituem assim.

O mesmo caso ocorre com inúmeras outras personagens de Blest Gana e em Martín Rivas temos dois bons exemplos. De um lado, Edelmira, uma jovem simples que pertence ao núcleo do medio pelo e de outro, e Doña Francisca, a esposa de Don Fidel Elías, um dos representantes da aristocracia do dinheiro. A primeira nos é apresentada pelo amigo de Martín Rivas, Rafael San Luis, que sobre a jovem comenta: “es una niña suave y romántica como una heroína de algunas novelas de las que he leído en folletines de periódicos que le presta un tendero aficionado a las letras." São tão marcadas as influências das leituras de folhetins em sua vida que é impossível pensá-la fora deste contexto. Reforçando esta imagem, o mesmo amigo, que também é um leitor, utiliza uma citação para melhor descrevê-la: “El corazón de está es como ha dicho Balzac de una de sus heroínas, una esponja a la que haría dilatarse la menor gota de sentimientos $" 93$.

Já Doña Francisca, que é de uma classe mais elevada, não chega a ser uma leitora tão fantasiosa, pelo contrário, ela é pragmática e procura estabelecer uma relação intelectual com os livros. Diferente da maioria das mulheres de sua época, ela ousa intrometer-se nas polêmicas discussões masculinas sobre política. Mesmo sob a censura de seu esposo, que sempre tenta reduzir seu espaço de fala, ela consegue expor suas afiadas convicções liberais, as quais são mais bem construídas e fundamentadas do que as opiniões flutuantes de seu cônjuge. E não por acaso George Sand ${ }^{94}$ é sua escritora favorita.

De posse destes exemplos introdutórios, sigamos com as personagens do romance El ideal de un Calavera, sobre as quais me debruço com mais cuidado. Neste

\footnotetext{
${ }^{93}$ BLEST, Gana. Martín Rivas, Martín Rivas (Novela de costumbres políticos-sociales) Prólogo, Notas y Cronología- Jaime Concha. Caracas: Ayacucho, 1977, p. 123.

${ }^{94}$ George Sand - Romancista francesa Aurore Dupin, baronesa Dudevant, usava o pseudônimo de George Sand. Seus livros eram muitos populares no século XIX.
} 
caso, tanto entre as personagens leitoras como entre as não leitoras, encontramos uma conexão do seu caráter conjugado à sua relação com a leitura ou a falta dela. Abelardo Manríquez, o protagonista da narrativa, é um leitor de um único livro e de algumas histórias de amor. Desde criança ele lê, sistemática e exaustivamente, a Correspondência de Abelardo e Heloísa, leitura excessiva que motiva a sua idealização do amor.

Essa idealização é o reflexo de sua própria personalidade sobre a qual a leitura assume o papel de espelho, que traz uma imagem nítida do amor, porém invertida. $\mathrm{O}$ jovem calavera Abelardo Manríquez é um decalque de suas leituras, ao mesmo tempo em que ele representa uma figura romântica, apresenta-se incrédulo, imoral e gozador. De maneira que todo seu caráter ambíguo aponta para a transgressão do tema amoroso, cujo arranjo pode ser notado no desenvolvimento da narrativa, por meio de suas ações de calavera, as quais, propositadamente, divergem daquelas do seu caráter romântico. Entretanto, quando se trata de sua expressão escrita, não podemos visualizar a mesma transgressão, isto porque diante deste suporte, a sua voz enunciativa perde a autenticidade que transgride a imagem romântica.

E a causa da ausência de transgressão na escrita de Manríquez está intrinsecamente ligada ao seu pequeno repertório de leituras, que por ser reduzido, limita sua capacidade de infringir o modelo, estabelecendo deste modo uma relação entre leitura/escrita. Se por um lado, as leituras realizadas pelas personagens de alguma maneira parecem configurar suas personalidades, pelo outro, as mesmas leituras são responsáveis pelo desenvolvimento dos modos de expressão escrita. Como dissemos anteriormente, a escrita das cartas de amor de Abelardo Manríquez apresenta alguns traços da escrita da Heloísa da Idade Média, posto que o jovem recorre às tópicas do amor cortês, oferecendo-se à sua amada de maneira mais submissa do que quando se declara pessoalmente.

Essa entrega hiperbólica sugere a modalização da escrita, ou seja, a influência da leitura da Correspondência de Abelardo e Heloísa aparece mais marcadamente sob o suporte da escrita do que em suas ações de fato. Seria como se neste campo ele possuísse uma menor autonomia de expressão, que possivelmente estaria pautada em decorrência do próprio formato predefinido pelas cartas de amor, que por si só já cria a separação entre a escrita e a realidade. Menos espontânea que sua fala, a sua escrita obedece a uma estrutura tópica amorosa, aliada é claro, à sua falta de repertório de leitura, que se constitui apenas das supostas cartas de Safo e Faón e da Correspondência 
de Abelardo e Heloísa, pois como comenta o narrador, Abelardo Manríquez não é muito estudioso: “Como a los once años leía con bastante corrección, gracias al formidable método ferulístico de aquellos tiempos, Abelardo pasó de la banda de Cartago, em cuyas filias militó en la escuela, al colegio en que debía estudiar alguna profesión. ${ }^{95}$ Envolta por esta certa artificialidade, a escrita de Aberlado Manríquez carrega nas tintas da fantasia e na idealização amorosa.

Relação similar entre leitura e escrita ocorre com Inés Arboleda, a destinatária das cartas de Abelardo Manríquez. A jovem é uma personagem alfabetizada, tanto que na primeira parte da narrativa, aparece supostamente lendo um livro que está em suas mãos, mas que ela não lê: "Sentada en un banco debajo del parrón, con un libro en su mano, el airoso cuerpo reclinado hacia la derecha y la espalda apoyada a un pilar, Inés miraba al frente y parecía embebida en su contemplación" ${ }^{96}$. Esta cena assemelhase às pintadas por James Jacques Joseph Tissot, o grande pintor de costumbrista francês do século XIX, que tem uma destacada coleção de retratos de leituras.

Especificamente a descrição que nosso narrador faz de Inés aproxima-se de um dos quadros do pintor, em que uma jovem, sentada confortavelmente em uma cadeira com o livro no colo, parece embalada pela leitura, entregar-se aos seus pensamentos românticos. Mas a julgar pelo desenho que o narrador nos apresenta sobre caráter de Inés Arboleda, percebemos que no romance não se trata de uma alusão a grandes leitoras, mas sim uma possível paródia pictórica, cujo sentido seria o de ironizar a simulação de caracterização da leitura.

O déficit de leituras aqui significa problemas na escrita, e as já mencionadas dificuldades de Inés para redigir a carta, em resposta a Abelardo Manríquez, são apresentadas pelo narrador de maneira cômica. Neste sentido, sobre as deficiências ortográficas de Inés, o narrador pausa a narrativa e refere-se ao ‘autor’ numa espécie de referência ao mundo externo: “era necesario hacerlo por escrito, y de aquí surgia una poderosa dificultad, que el autor se ve precisado a enunciar francamente, a fin de no quitar a su historia el sabor de la realidad, tan importante en los estudios de costumbres." 97

Este recurso é um procedimento recorrente na narrativa e funciona como um reforço para o efeito de autenticidade da trama. A referência externa é chamada de

\footnotetext{
${ }^{95}$ BLEST, Gana. Op. Cit. 1908. Tomo I, p.16.

${ }^{96}$ Ibid., p. 30-40.

${ }^{97}$ BLEST, Gana. Op. Cit. 1908,Tomo I. p.126.
} 
sabor da realidade pela voz do narrador que possui o absoluto domínio sobre os pensamentos das personagens. Onisciente, faz-nos conhecer o engenhoso método que a jovem inventa para não demonstrar sua falta de cultura.

A forma cômica de demonstrar o temor de Inés diante das tirânicas exigências das regras ortográficas cumpre uma função clara que nos dá um retrato bastante coerente da educação feminina da época. Pois não se detém somente nas dificuldades de escrita, mais que isto, a passagem também apresenta a existência de um espaço dedicado à leitura, a biblioteca da casa dos Arboleda, que nem chega a ser de toda a família, e sim apenas de parte dela, pois pertencia à mãe e à irmã de Inés, sendo formada por um pequeno acervo de livros devotos, que representam o reduzido repertório de leitura do grupo social. Segundo o irônico narrador, Inés não lê porque sua beleza dispensa este costume. Já o mesmo não diz de sua irmã Andrea, que desprovida de atrativos físicos, dedica-se, assim como a mãe, mais à religião e à leitura de livros devocionários como compensativo para solidão.

A passagem que mostra as estratégias de Inés para responder a carta de Manríquez tem lugar entre os anos de 1835 a 1836, período em que o Chile estava sob o comando de Diego Portales, época em que havia ainda certas dificuldades para a entrada de livros estrangeiros e para a produção de materiais impressos. A leitura não era um hábito presente no país e o pouco que se lia eram livros religiosos e devocionários, que desde os tempos coloniais, circulavam com maior facilidade. O ideal de educação laica em território chileno só se iniciou concretamente após 1842, com o fortalecimento das instituições republicanas, cujo marco histórico foi a fundação da Universidade do Chile, que veio substituir a Universidade de San Felipe, organizada em 1747 pelos jesuítas.

Dialogando com este passado, o narrador desloca-se para o seu presente, e projeta um distanciamento narrativo que incorpora os dois níveis de tempo, o passado e o presente, aproximando-se assim, de alguma forma de seu leitor contemporâneo. Este narrador, que fala desde 1863, parece acreditar numa visão positiva da evolução histórica, a qual lança um olhar distorcido sobre a carência de livros e de leituras da população chilena da primeira metade do século XIX.

Ainda no que tange à precariedade da educação da época, temos as irmãs Candelaria e Martina, juntamente com o pai, Don Raimundo Basquiñuelas, além de Timoleón Miraflores e outras personagens secundárias que apresentam cenas não menos hilariantes do que a protagonizada pela rica Inés Arboleda. Sempre permeados pela comicidade, estes quadros estão a serviço de uma séria reflexão sobre o corpo social 
chileno, que se mostra por uma perspectiva liberal em que as defasagens na educação refletem os atrasos civilizatórios.

Ao longo do romance, são 36 cartas escritas pelas personagens. No entanto, na maioria delas, os comentários são partes mais relevantes do que os próprios conteúdos das cartas. Estes apartes são questões e reflexões levantadas, ora pelo narrador, ora pelas próprias personagens, sobre as dificuldades de escrita de alguns emissores ou de compreensão de leitura dos destinatários das cartas. Vale à pena se deter nestes momentos com mais cuidado, pois há neles a contextualização do ato de escrita e leitura das cartas intercambiadas pelas personagens.

Candelaria recebe uma carta, supostamente escrita por Abelardo Manríquez e sua irmã Martina recebe uma de Felipe Solama. Entretanto, ambas foram escritas por Felipe, pois o calavera, após sua desilusão com Inés, recusa-se a voltar a escrever cartas de amor. Felipe Solama é advogado e, assim como Abelardo Manríquez, é também um leitor, com a diferença que suas leituras são mais extensivas, possuindo um tom mais filosófico, o que não significa que gerem ideias mais elaboradas. Solama não perde a oportunidade de demonstrar sua erudição. Mesmo em conversas banais, sua imaginação flutua desregradamente, elevando todo tipo de assunto à categoria da metafísica. Aparte disto, não se pode negar que ele tenha domínio sobre a expressão escrita, pois ao cabo de um pequeno espaço de tempo escreve duas cartas de amor, de caráter completamente diferente. Na que escreve como se fosse Manríquez, encarna uma personalidade passional, bem condizente com ao comportamento impulsivo do calavera:

\section{“Candelaria de mi alma:}

El que me ha separado de Vd. recibirá algún día su castigo; entretanto, si Vd. me ama, deme una prueba de ello facilitándome los medios de verla. Mi amor se ha aumentado con la ausencia y si Vd. no pone terminó á ella, no respondo de mí: cegado por mí pasión, soy capaz de ir á arrebatarla del seno de su familia." ${ }^{8}$

Já como ele mesmo, Felipe Solama escreve uma carta mais própria do seu estilo empolado:

\section{“Martina mía:}

En vano nos separan! Qué son los obstáculos materiales para dos almas que tienen el poder de encontrarse en la infinita y mágica

\footnotetext{
${ }^{98}$ BLEST, Gana. Op. Cit. 1908 Tomo I. p. 265.
} 
región del sentimiento? ¡Jamás podrán los verdugos encadenar el pensamiento, ni los padres tiranos hacer bajar á la prosa de lágrimas estériles, á dos seres capaces de desprenderse del mundo por la fuerza sublime de una inmensa adoración! Por esto quedo tranquilo, esperando que ni la ausencia ni el tiempo borren de su pecho mi imagen, como nada tendrá la fuerza de borrar la suya que besa el alma del que la adora" ${ }^{99}$

Timoléon, que está com os outros dois calaveras no momento da elaboração destas missivas, comenta após a leitura da carta destinada a Martina que não entendeu nada. O jovem advogado logo explica: “- Ella tampoco entenderá [...], y eso es lo mejor: toda pasión es amante del misterio”. Pelo mistério que mais parece “una ensalada de sentimientos” dá para imaginar a confusão da jovem de medio pelo ao ler e tentar responder esta carta. Sem entender exatamente o que diz a carta, Martina em resposta escreve: “Querido Amigo, Casi me da vergüenza escribirle porque usted es tan sabio y yo no sé nada pero sé querer á quien me quiere y espero verlo" ${ }^{100}$ [...]. E Felipe Solama após recebê-la, ironiza as faltas gramaticais “-Hay más pasión que ortografía",101

As irmãs Basquiñuelas escrevem as respostas mais tomadas pela emoção do que por preocupações com as regras ortográficas. Para evitar comprometer o entendimento, o narrador diz ironicamente ter suprimido os erros ortográficos em nome da claridade do texto, mas que, para não modificá-lo totalmente, conserva os problemas de pontuação. Novamente o narrador usa aqui o procedimento que produz um efeito de verossimilhança que pretende poupar o leitor dos problemas que traz a suposta carta real.

Em outro momento, o narrador tenta relacionar a personagem Candelaria a uma parcela da sociedade, que embora seja alfabetizada, apresenta dificuldade de comunicar-se pela expressão escrita, por causa da falta de repertório de leitura, que o próprio autor sugere como correlata: “Después de decifrarla con gran atención, a causa de su poca prática en a lectura epistolar, la joven llegó a leer corrientemente lo que sigue $^{102}$ [...] Tal correlação aparece também evidenciada em outras passagens que vinculam o tom humorístico a um quadro da precária educação do país para denunciar o atraso civilizatório, que segundo este narrador não respeita nem a divisão de classes.

\footnotetext{
${ }^{99}$ Ibid., p. 265.

${ }^{100}$ Ibid., p.265.

${ }^{101}$ Ibid., p. 265.

${ }^{102}$ BLEST, Gana. Op. Cit. 1908, Tomo II. p. 21.
} 
Pois tanto o pai de Candelaria, Don Raimundo Basquiñuelas, apresenta dificuldade para ler a carta que recebe de sua filha: "se echó hacia atrás su sombrero, púsose los anteojos y leyó la carta con voz nasal y difcultosa dicción"; ${ }^{103}$ como o velho rico Don Lino Alcunza, que também é ironizado pelo narrador quando escreve uma carta com faltas ortográficas a jovem Candelaria.

Aparte dos equívocos ortográficos está a correspondência trocada por Abelardo Manríquez e Felipe Solama, enquanto o 'oficial de húsares' aguarda o julgamento que o levará ao fuzilamento. Diferentes das demais cartas, estas são bem elaboradas e também tomam de fato um papel informativo, pois acabam substituindo, ao longo de um capítulo inteiro, a voz do narrador. Através das cartas dos amigos nos informamos do destino de Abelardo Manríquez e dos acontecimentos nas vidas das demais personagens.

\section{6.- A Punição do DESEJo}

A proposta de análise que entrelaça a figura ambígua de Abelardo Manríquez com a sugerida intertextualidade com seu famoso homônimo Pierre Abelardo, privilegia também um esforço crítico que objetiva destacar as oscilações do protagonista entre o papel de herói e anti-herói, de sedutor e vítima do amor, entre tantos outros possíveis pares opostos. De um extremo a outro, a visão que temos da personagem não é maniqueísta, mas sim contraditória. Como se estivéssemos postados diante de um caleidoscópio em alta rotatividade, a imagem de Abelardo Manríquez é apresentada de maneira disforme. Suas virtudes e os seus defeitos confundem-se, através das palavras irônicas do narrador, configurando desse modo uma personagem arbitrária e na contramão de sua época.

Abelardo Manríquez é um típico calavera, esta não é a primeira vez que o autor observa este tipo social, outro representante dessa classe já havia aparecido no romance anterior, Martín Rivas. A personagem do libertino Amador Molina que compõe o núcleo do médio pelo nesse romance, é classificada pelo narrador como um

${ }^{103}$ Ibid., p.145. 
exemplar curioso da humanidade que, por sua expressão, merece um estudo mais detalhado.

O cronista espanhol, Fígaro, em seu artigo Los calaveras confessa que não sabe certamente qual a relação existente entre un calavera y una calavera. A não ser pelo o excesso de vida que se atribui ao primeiro e que, obviamente, falta ao segundo, qualquer outra aproximação nessa linha ganharia um tom pejorativo. A tentação de relacionar o vazio da cabeça de um para o outro, conduz a um equívoco sobre o talento e o juízo dos representantes desse tipo social. Pois, como veremos através dos exemplares de calaveras presentes no romance, para ser um deles, ao contrário do que se pensa, são necessárias boas doses de talento e juízo.

Ao protagonista Abelardo Manríquez não faltam os referidos atributos, além de lhe somarem outros. Ele se destaca do vulgo tanto por seus encantos físicos, como por suas qualidades morais, tudo nele revela nobreza. A graça natural de seu corpo, em harmonia com a poderosa expressão de seu olhar, realça as linhas de seu rosto branco perfeitamente desenhado. Os cabelos castanhos e abundantes escondem as pequenas orelhas levemente rosadas. A beleza de Abelardo Manríquez é de uma delicadeza quase feminina, que por sua vez, reflete os atributos de sua alma sensível que remete diretamente a sua beleza interior:

\begin{abstract}
Abelardo Manríquez no era un ente vulgar. Muy poco lo tentaban los bienes materiales, á los que, en nuestros días se enseña á la juventud á rendir un culto fervoroso. Llevaba en su alma, turbulenta por la savia de la juventud, esa chispa de aspiración vaga, que sólo se anida en los pechos de aquéllos que nacen organizados para distinguirse del vulgo. ${ }^{104}$ (sic)
\end{abstract}

Diferente da maioria da juventude de seu tempo, ele não tem apego ao dinheiro, cargos ou posição social. Consagra sua vida à busca de um ideal de amor, tendo como ambição única ser amado por uma mulher de sentimentos puros e livres das normas sociais. O narrador descreve Abelardo Manríquez com os qualificativos que ele acredita serem responsáveis por formar grandes escritores, sábios, guerreiros e amantes. Envolto em uma aura heroica e elevada, esta personagem está pronta para conquistar os leitores de almas sensíveis para os quais o autor dedicou o romance. Conduto, nem todos simpatizam com a causa deste jovem. Em uma carta enviada a Blest Gana, o

${ }^{104}$ BLEST, Gana. Op.Cit. 1908, Tomo I. p. 22. 
amigo Lastarria em 25 de Janeiro de 1864, comenta que Manríquez não lhe agradava. Em resposta, o escritor diz:

No sé por qué no le agrada Manríquez: todo llevamos en el pecho un grano de esa aspiración a que consagró su vida, y el que no la lleva fraile impunemente. Manríquez tiene irresistible el instinto que otros hombres de corazón moderan por conveniencia por hipocresía o por moralidad; el instinto que el Querubín de Beaumarchais expresa con tan infantil sencillez cuando dice que quisiera abrazar a todas las mujeres en una sola. Yo tengo cariño. Es un Werther que se habría reído de los escrúpulos de Carlota: tipo, si Ud. Quiere, de la inmoralidad que en materias de amor profesan la mayor parte de los hombres. Pero que lleva la chispa sagrada de esa necesidad de adoración que es el más poderoso móvil de las acciones humanas. ${ }^{105}$

Se para Blest Gana, Abelardo Manríquez é um Werther que se habría reído de los escrúpulos de Carlota, para Alone, o mais influente crítico literário do Chile da primeira metade do século XX, Abelardo Manríquez é um Don Juan exigente ${ }^{106}$. Sedutor ou vítima do amor? Don Juan ou Werther? ${ }^{107}$ Nem um nem outro, melhor seria pensá-lo como um e outro. Paradoxal, no entanto, bastante coerente na composição da personagem, Blest Gana busca na personagem de Goethe a inspiração romântica, e em Don Juan, todo seu caráter sedutor e amoral que qualifica, ao mesmo tempo, o seu herói como anti-herói.

Avesso às convenções sociais, Abelardo Manríquez, segue na contramão da sociedade chilena dos oitocentos, semelhante ao movimento que ocorre com a personagem de Cervantes, ele idealiza um sonho estranho ao seu tempo e ao próprio estilo da narrativa. O enredo tem lugar entre 1814 e 1838; desses anos, os últimos três se destacam por concentrarem os acontecimentos mais importantes da trama. A vida do protagonista compreende justamente o período em que o Chile estabelece os primeiros passos para a consolidação de sua independência. A transição da colônia para a nacionalização do estado chileno acarretou algumas alterações nos hábitos e costumes do meio social, que o caráter realista empregado pelo autor, aponta com bastantes detalhes.

\footnotetext{
${ }^{105}$ FERNANDEZ. Larraín. Sergio, Op. Cit. p. 57.

${ }^{106}$ Alone em seu breve estudo sobre El ideal: A ese precio y sólo a ese precio, Abelardo Manríquez, Don Juan exigente, de una clase social intermedia, se confesará dichoso ALONE. Don Alberto Blest Gana. Biografia y critica. Editorial Nascimento: Santiago- Chile. MCMXL. 1940. p.167.

${ }^{107}$ Ver. INGENIEROS, José. Tratado del Amor. Buenos Aires: Editorial Losada S. A, 1970.
} 
Os acontecimentos históricos presentes no romance funcionam, conforme as já mencionadas pretensões de Blest Gana, como um "sello de nacionalidad”. Entretanto, isso não significa que os argumentos históricos se limitem, exclusivamente, a desempenhar o papel de distinção entre um romance chileno e outro estrangeiro, pelo contrário, na trama do calavera eles participam como elementos constituintes da composição da obra. Tal é a relação da obra com o contexto no qual se insere a narrativa, que esses acontecimentos históricos e sociais deixam de ser apenas fatores externos para cumprirem uma importante função na constituição da estrutura do romance. Como bem apresenta o mestre Antonio Candido, ${ }^{108}$ a história dentro de um romance é um elemento social que permite identificar na matéria narrada a expressão de uma época. Externa à ficção, a história se transforma em construção artística para explicar e não para ilustrar a sociedade representada.

Essa perspectiva da relação histórica social é um dos possíveis meios para a compreensão da configuração ambígua do protagonista. Abelardo Manríquez é um herói pela nobreza de seu coração e por sua beleza física, mas ao mesmo tempo é um antiherói, porque repudia as convenções sociais em favor de uma união rebelde e autêntica. À margem do que seria a nova sociedade normativa do século XIX, ele ocupa o que se pode chamar de um não lugar social. Enquanto a sociedade chilena ambiciona o êxito econômico social, que se encontra tão bem representado pela família Arboleda, Abelardo Manríquez ambiciona ser amado.

Dentro do contexto social representativo da sociedade chilena no romance, os sentimentos do jovem calavera são satirizados pela sua inadequação com hábitos e costumes sociais da época. Seu ideal quimérico marca o conflito entre ele e a totalidade social. O amor idealizado por Abelardo Manríquez não resiste à realidade que o cerca. O primeiro embate acontece quando reconhece como falsas as esperanças de encontrar, em Inés, sua Heloísa. Logo em seguida, o calavera deixa a pequena cidade, vai para Santiago, onde inicia sua carreira militar, ocupando o posto de 'oficial de húsares', o que dá início à segunda parte da obra, "II Los Calaveras”, a qual é praticamente independente da primeira.

Nesse novo contexto, na capital chilena, Abelardo Manríquez conhece Candelaria Basquiñuelas, uma jovem de condições mais modestas, que ao contrário de Inés, corresponde com sinceridade aos seus sentimentos. A princípio, a constância da

${ }^{108}$ CANDIDO, Antonio. “Crítica e Sociologia (tentativa de esclarecimento)”. In: Literatura e Sociedade. São Paulo: Companhia editora Nacional, 1976. p. 4. 
jovem poderia resolver o conflito da busca do ideal do calavera, mas o calor da paixão que une Candelaria a Abelardo não suporta a força das convenções sociais.

Vale aqui uma breve paráfrase do enredo do episódio. Don Lino Alcunza, concorrente de Abelardo ao coração de Candelaria (sempre há um concorrente para o triângulo romanesco), facilmente convence Don Raimundo Basquiñuelas, pai da jovem, de que as frequentes visitas de Manríquez e seus amigos, Felipe Solama e Timoleón Mira Flores, podem manchar a reputação das filhas, pois não há neles intenção alguma de casamento. Audaciosos, os jovens calaveras armam uma estratégia para voltar a visitar as filhas de Don Raimundo e ao mesmo tempo vingar-se de Don Lino Alcunza. Num magnífico banquete secreto que oferecem na casa dos Basquiñuelas, depois que Don Raimundo se deita, eles envenenam o rival com uma tortinha com recheio de carne temperada com purgante.

Após o jantar, os amigos são surpreendidos pelo pai das jovens e num cômico embate todos saem da casa, menos Manríquez que se esconde no quarto de Candelaria. Embalado por um rompante amoroso, o calavera pede à jovem que fuja com ele como prova de seu amor. Candelaria não resiste ao caprichoso pedido e foge com o amante.

Semanas após a fuga do casal, ela se vê enclausurada em uma pequena casa, e arrepende-se por ter abandonado sua família. O casamento parece para ela como uma solução para reaproximá-la do pai, e também como o único acesso para a retomada da vida social. Entretanto, o pedido de Candelaria Basquiñuelas representa uma nova desilusão para Abelardo Manríquez. Posto que o amor que ele idealiza, melhor dizendo, como o compreende Heloísa, não exigia o casamento, pelo contrário, para ela, "este empanaria a glória dos amantes. [...] preferia o título de amante ao de esposa, e o considerava mais honroso [...], [Abelardo] estaria ligado a mim apenas pela ternura, não pela força do laço nupcial”. ${ }^{109}$

A impossibilidade de realizar seu ideal romântico faz com que Abelardo abrace de modo veemente a causa liberal no conflito de 1837, precipitando de alguma maneira seu trágico final. Participa do motim em Quillota contra o líder conservador Diego Portales, mais motivado pela aventura, do que pela causa liberal. Numa atitude temerária, após o levante responsável pela morte do primeiro ministro a ser derrubado, o jovem permanece em seu posto quando chegam os oficiais do governo. Capturado, em

${ }^{109}$ ZUMTHOR, Paul. Op. Cit. p.49. 
momento nenhum tenta se defender das acusações de traição e aceita a pena de morte como uma atitude de resignação final diante da vida adversa.

Manríquez parece ser um herói romântico, sublima seus anseios amorosos pelos ideais liberais, abraça a causa com tanta sinceridade que prefere antes a morte a sobreviver sem realizar seu ideal. Sobre estes heróis românticos, Isaiah Berlin diz que para eles: “acima de tudo, o desafio - que envolvia uma luta perpétua contra a convenção [...] lutar e, se necessário fosse, morrer eram atitudes bravas, corretas $e$ honradas, enquanto transigir e sobreviver era covardia e traição", ${ }^{110}$

Esse trecho, retirado do texto $A$ apoteose da vontade romântica - A revolta contra o mito de um mundo ideal, não deixa dúvidas de que podemos pensar em Manríquez como num discípulo da filosofia romântica, sendo a alusão que Blest Gana faz de Goethe, uma menção nada casual. Até mesmo a teoria elaborada pela personagem Felipe Solama sobre as almas huérfanas, representa uma referência ao pensamento romântico. Segundo ele, são almas huérfanas: “Todos los que se apartan del movimiento general por algunos atributos extraños á las almas vulgares, son huérfanos: para ellos las espinas de la vida.” 111

Se de um lado, Abelardo Manríquez só parece receber os espinhos da vida, por outro, ele é o próprio espinho para sociedade chilena representada no romance. Conforme Leo Bersani, o desejo dentro de uma narrativa realista desequilibra a requerida ordem social representada e cria um temor sobre a possibilidade de uma subversão iminente ${ }^{112}$. Sua personalidade romântica perturba a ordem social estabelecida, e a impulsividade que move seu ideal, no episódio da tentativa do rapto de Inés, poderia ameaçar os planos do vantajoso casamento com o endinheirado Miguel Sendero que garante o futuro econômico da família Arboleda. Já o envolvimento amoroso com Candelaria corrompe a família Basquiñuelas, porque ainda que o rapto da jovem de medio pelo não signifique um escândalo social, seu desfecho é negativo para ela que, por conta disto, acaba caindo nas mãos do inescrupuloso “calavera, sênior" Lino Alcunza.

O desejo romântico não é assimilável aos costumes e hábitos sociais burgueses pós-coloniais da primeira metade do século XIX no Chile, e a incompatibilidade neste

\footnotetext{
${ }^{110}$ BERLIN, Isaiah. “A apoteose da vontade romântica - A revolta contra o mito de um mundo ideal.” In: Estudos sobre a humanidade- uma antologia de ensaios. São Paulo: Cia das Letras, 2002. p. 565.

${ }^{111}$ BLEST, Gana. Op. Cit. 1908.Tomo II. p. 55.

${ }^{112}$ BERSANI, Leo. Op.cit. p.70.
} 
caso só pode ser solucionada através da expulsão social do dito subversivo. Na narrativa de Blest Gana, essa expulsão se dá pela condenação do protagonista pela própria sociedade que cobra a punição dos assassinos de Diego Portales.

Por uma das cartas de Felipe Solama enviadas a Abelardo Manríquez, o jovem advogado marca sua posição de apoio ao motim liberal nos contando a opinião popular sobre o líder conservador: “iPortales es un semidiós, segun todos aquí, y Vds. son unos verdugos!” 113 No que se segue, ele faz um comentário irônico que remete à flexibilidade de opinião da sociedade chilena que, historicamente, define seu apoio mais por conveniência do que por relações ideológicas : “Todos por supuesto, han ocultado los laureles con que pensaban coronar la victoria de Vds. En fin, así es el mundo.”114

Dialogando com o acontecimento histórico no nível explicativo, nos termos que aponta Antonio Candido, vemos o episódio histórico do Motim de Quillota completamente integrado ao desfecho da narrativa, pois é a partir dele e de suas consequências sociais que se define a sorte do protagonista e a representatividade desta sociedade que de alguma maneira tende a se esquivar, tanto das convicções conservadoras, quanto das liberais.

Nesse sentido, com a morte de Abelardo Manríquez, uma personagem disposta a levar esta e outras causas às últimas consequências, o autor evita o choque do herói intruso com o meio-social e, dessa forma, poupa a sociedade de um conflito que poderia ser mais profundo.

Se para a família Arboleda a condenação do calavera representa a retomada da ordem social e moral, para a família Basquiñuelas isso não acontece. Porque, apesar de Abelardo Manríquez ser o elemento desencadeador da perdição de Candelaria, a desventura dela não poderia ser evitada. Uma vez que o amor que nutre pelo calavera é apenas um passo em direção a um futuro que já está previsto para ela pelo narrador, desde a apresentação da personagem, confirmando o adágio popular, cada qual é para o que nasce.

Por uma descrição pormenorizada da jovem de medio pelo que vai das características físicas às morais, o narrador relaciona harmoniosamente sua beleza com sua índole moral. Os contornos do corpo de Candelaria parecem traçar o seu destino, o coração que aspira ao prazer e ao luxo é revestido por atrevidas formas que, segundo seu ponto de vista, inspiram idílios profanos:

\footnotetext{
${ }^{113}$ BLEST, Gana. Op. Cit. 1908. Tomo II p. 337.

${ }^{114}$ Ibid., 337.
} 
Su físico correspondía a su organización moral: había en estas dos partes de su ser una armonía perfecta. El cuerpo torneado sin ser prosaicamente gordo, el seno de atrevida forma, el cuello flexible y redondo, parecían formados para inspirar idilios profanos, que entona el corazón á la belleza material, cuando ha perdido la imaginación del lirismo de la inocencia y le queda todavía el fuego de la juventud. Los ojos, que eran negros chispeaban la lozanía y la pasión, formando una hoguera cuya llama atraía irresistiblemente, como mariposas, los corazones ávidos de amor. [...] reinaba en su fisonomía un aire de voluptuosidad, propio sólo de algunos rostros de mujer, que poseen la inimitable pureza de la virginidad, sin tener el candor que dan las ideas adormecidas en el limbo de una casta inocencia. $^{115}$

Com efeito, as características físicas de Candelaria, segundo o juízo determinista da época, encarnado no narrador, prenunciam o seu porvir após o rompimento com Abelardo Manríquez. Mas isso não está colocado como consequência, posto que a jovem já trazia em sua fisionomia a voluptuosidade disfarçada pela candura.

Em termos formais, todas as personagens são planas, não há complexidade nem modificações estruturais ou eventos capazes de transformá-las. Há apenas ameaças relacionadas às ações de Manríquez que logo se dissolvem após sua morte. Ponto crucial, não por acaso, a cena do fuzilamento do calavera aparece tanto no início quanto na parte final, de modo que a narrativa desenvolve-se entre o espaço de ida e vinda ao incidente inicial.

O fuzilamento de Abelardo Manríquez, mártir do motim de Quillota, simboliza a condenação de sua forma impulsiva e romântica de atuar no mundo. Segundo o raciocínio de Leo Bersani, a personalidade do calavera é incompatível com as normas sociais do seu contexto, seu ideal amoroso e suas ideias libertinas representam uma ameaça à ordem social, que só se restabelece com a consumação do sacrifício. Com a sua morte, as peças vão, pouco a pouco, retornando a seus lugares de origem no tabuleiro, traçando deste modo, um reajuste social que, por um lado, destaca a visão irônica e crítica do narrador sobre a sociedade chilena e, por outro lado, assegura e divulga o brilho do herói sacrificado.

São efeitos opostos, que derivam de um único impulso contra um objeto de movimento pendular. A análise do movimento flagra como a figura atraente, espirituosa e divertida que compõe a personalidade de Abelardo Manríquez é instituída para o

${ }^{115}$ BLEST, Gana. Op. Cit. 1908. Tomo I. p. 158. 
fracasso. De maneira enfática, novamente nas palavras de Bersani: “No século XIX, os personagens que recusam aceitar os limites que a sociedade impõe ao sujeito, à sua natureza e à extensão de seus desejos, tornam-se os bodes expiatórios desta sociedade."116

De fato, Abelardo Manríquez é um bode expiatório. Sem lugar social, a composição de sua personalidade advém de um intrincado jogo, cujo sentido irônico ergue-se por conta da reestruturação da temática romântica para uma narrativa que se pretende realista. Este movimento do ideal romântico para o romance realista poderia, em princípio, parecer algo da ordem do contraditório, mas ao invés disto está longe de ser um desrespeito ao senso realista. Pois, através da subordinação de uma leitura à outra, Blest Gana consegue definir com maior clareza os espaços de dentro e de fora dessa representada sociedade chilena do século XIX.

Fora desta sociedade, o protagonista encontra-se duplamente marginalizado. Primeiro por conta de seu ideal romântico, e segundo pelo mal-estar advindo da arbitrariedade dos hábitos e costumes da moderna sociedade. Mas para além das fronteiras sociais, temos também as implicações internas da personagem, pois os sentimentos idealizados por Abelardo Manríquez não se conectam de modo algum ao seu papel de calavera.

Todos esses elementos juntos transformam a trágica história de Abelardo Manríquez em um drama bufo-trágico, no qual o ideal de amor é reduzido a um capricho, que nada mais é do que o resultado puro e simples da desmedida ideia fixa. Em outras palavras, poderíamos dizer que o desejo da personagem perturba a ordem social estabelecida e, por essa incompatibilidade, o herói é ridicularizado é condenado pela sociedade desde o início do livro. Contudo, há um contraditório dialogismo, o qual se instaura na figura do narrador que ao mesmo tempo o condena e o admira.

\section{7 - UM CHILE COLONIAL-MODERNO}

A história chilena, que está por diversos momentos entrelaçada ao enredo, ganha mais força com a inserção no romance de uma personagem que parece carregar a

${ }^{116}$ BERSANI, Leo. Op. Cit. p. 76. 
história do Chile em sua figura. O pai de Candelaria, Don Raimundo Basquiñuelas, é uma personagem representativa de sua época, sua trajetória é marcadamente traçada em sua descrição física e moral, tudo nele revela o passado chileno. Seguindo o mesmo sentido da análise Auerbach do Vermelho e o Negro de Stendhal, podemos perceber que o caráter, as atitudes e relações do chefe da família Basquiñuelas estão estritamente ligados ao momento histórico que ele vivencia. ${ }^{117}$ Observemos o perfil de Don Raimundo Basquiñuelas:

El padre de las tres jóvenes, vestía un traje de paño negro que evocaba recuerdos de antiguas modas, al propio tiempo que en otras, presagiaba las modas contemporáneas. Componíase de un frac de cuello derecho en la forma de algunas en que pinturas representan a los beaux ó elegantes del directorio francés, que sucedió á la Convención de borrascosa memoria. [...] Este frac, el sombrero y el calzado eran las prendas más notables de aquel traje, pues el chaleco y los pantalones eran de forma moderna. Ese sombrero de copa alta y ancha en la parte superior. iba disminuyendo hacia fuera, recordaba los antiguos morriones de tropa. El calzado no era notable por su forma; pero sí por su clase $[\ldots]^{118}$

Uma atenção especial deve ser dada ao figurino da personagem que, precisamente datado, representa a conflituosa transição do passado colonial ao futuro do Chile independente e moderno. A carga simbólica e significativa da caracterização das personagens é um recurso utilizado em mais de uma oportunidade nos romances de Blest Gana. Um exemplo disso é observado na descrição da indumentária do protagonista de Martín Rivas em sua chegada a Santiago, no início da narrativa. Durante o desenvolvimento da trama, as roupas que denunciam a sua origem provinciana, vão sendo substituídas por peças mais adequadas às modas citadinas, em compasso com seu ingresso social.

Nesse sentido, o corpo de Don Raimundo é divido em duas partes, uma superior e outra inferior. A parte superior veste um frac que evoca as antigas modas dos tempos coloniais, enquanto que a inferior, traja uma calça de forma moderna, nessa divisão temos num só corpo, duas histórias, duas vontades e, por uma perspectiva ainda mais expressiva, a transição contraditória dos novos tempos.

A contradição do vestuário simboliza as angústias desse velho cidadão que transitou pela história chilena, vivenciou o período colonial, assistiu a Revolução da

\footnotetext{
${ }^{117}$ Ver AUERBACH, Erich. “Na Mansão de la Mole”. In: Minesis: A representação da realidade na literatura ocidental. São Paulo: Editora Perspectiva, 1976.

${ }^{118}$ BLEST, Gana. Op. Cit. 1908. Tomo I. pp. 155-156.
} 
Independência e agora olha com desconfiança para o futuro do país. Contudo, a complexidade da personagem não se completa com suas reflexões, mas sim, pelo vazio de seus pensamentos. Don Raimundo não se detém sobre o futuro, suas recordações das cenas das batalhas de independência e as saudades de sua falecida esposa tomam a maior parte de suas meditações. Sobre o presente pouco pensa, visto que como comenta o narrador: "Ignorante de la ley del progreso indefinido del humano linaje, tan ponderada en el día, él no miraba con gran detención al porvenir: vivía de los recuerdos de su muerta consorte y de algunas escenas de la revolución de nuestra independencia” ${ }^{119}$. Suas únicas reais preocupações são o parco salário que o Estado lhe paga em troca de seu serviço de fiscal e a satisfação de seu grande apetite.

Don Raimundo Basquiñuelas e Abelardo Manríquez enfrentam os desajustes com o meio social, diante da conjuntura da narrativa. No caso de Don Raimundo, o embate é representado de maneira indireta e mais corrosiva. Enquanto o jovem é tomado de golpe, o ancião é assolado lentamente, sua cerimônia de expulsão está em diversas circunstâncias. Vejamos um dos momentos mais expressivos:

[...] el verdadero tipo del antiguo empleado, tipo al que las nuevas costumbres, hijas de diversas necesidades, van haciendo desaparecer de las oficinas.[...] don Raimundo Basquiñuelas sentado delante de su mesa, en una poltrona cuyo asiento de crin había gastado el uso. Para remediar este inconveniente, don Raimundo, sobreponía una especie de rodela de bandana, rellenada con crin: las patas y el respaldo de la silla eran tan venerables como el empleado que sostenían y como la mesa de caoba de paño verde, raído por el uso y manchado con tinta en varias partes. Sobre esta mesa se veía un tintero, algunas plumas de ave, varios legajos de papeles y un brasero para encender cigarro ${ }^{120}$.

O presente quadro pintado por Don Lino Alcunza é descrito com sarcasmo pelo narrador que abusa do uso do discurso indireto para imprimir a representação de uma figura em vias de extinção. O anúncio é claro, Don Raimundo não vai sobreviver aos novos costumes que a nascente modernidade chilena exige de seus cidadãos. Contudo, não se trata aqui de um extermínio tomado da realidade, pelo contrário, faz-se da literatura um exemplo para o comportamento social. Retomando a fala de Blest

\footnotetext{
${ }^{119}$ BLEST, Gana. Op. Cit.1908. Tomo I pp. 155-156.

${ }^{120}$ BLEST, Gana. Op. Cit. 1908. Tomo II. pp. 256-255. (*grifos nossos)
} 
Gana, na Advertência que precede a narrativa, destaca-se o apelo pela utilidad social, que sacan á la novela del campo estéril en que se encierra el mero pasatiempo. ${ }^{121}$

Nessa direção, cabe ao romance um papel civilizatório, representado pela função de preparar e disciplinar os cidadãos a conviver com as transformações que pouco a pouco se instauram pelo país. De modo quase caricatural, o narrador constrói, na personagem de Don Raimundo, uma imagem negativa do passado que acentua a incompatibilidade dele com o tempo da narrativa. Qualificado como antigo, o empregado é uma extensão de seu escritório, a poltrona mortificada e remendada ora confunde-se com o ancião, ora com a história do país.

Sob a perspectiva da história chilena, a cena imprime uma crítica ao governo conservador que dominava o Chile até então. Blest Gana que sempre apoiou os movimentos liberais e costumava declarar abertamente sua oposição ao falecido líder conservador Diego Portales ${ }^{122}$, encontra na figura de Don Raimundo, conjugada ao seu espaço de trabalho, um ensejo para reprovar a administração do país. Nessa direção, marca a conservação de um padrão próximo aos tempos do comando espanhol, cujas pequenas mudanças foram mero remendos para cobrir buracos causados pelo uso.

Como vimos, após a morte do ditador, o comando do país passou a ser mais flexível às ideias dos opositores e de um modo geral modernizou-se. Com efeito, se relacionarmos a imagem de Don Raimundo com o período de governo do primeiro ministro, poderemos associar o fim de um ao do outro. Embora o assassinato do líder não tenha acarretado de fato a substituição do governo conservador, as modificações empreendidas já formaram suficientes, para tornar a vida do antigo fiscal público incompatível com os novos tempos. Certamente, Don Raimundo não se harmonizaria com as transformações advindas do progresso e da modernidade.

\footnotetext{
${ }^{121}$ Ibid. Tomo I. p.VII.

${ }^{122}$ A oposição contra Diogo Portales aparece também na obra El loco Estero publicada em 1909.
} 


\section{CAPÍtulo}

\section{O Drama Bufo-TRÁgico}

No início da terceira parte do romance, o narrador pausa a narrativa e, dirigindo-se ao leitor, diz: "En el instante en que se abre este tercer acto del drama bufón y trágico que compone la vida de Abelardo Manríquez, la joven dejó el sofá en que se hallaba sentada y se dirigió precipitadamente a la puerta de la pieza” ${ }^{123}$. Deste trecho interessa-nos destacar a expressão “drama bufón y trágico” que dá título tanto a esta dissertação como também ao presente capítulo. A expressão tomada de empréstimo representa, a nosso ver, a composição que melhor explica as ambiguidades que permeiam a narrativa. Propositalmente ajustados, os apelos trágicos e cômicos causam a comoção e o riso, de modo que o leitor ora se identifica com o drama do herói, ora o repudia em favor do riso.

Insinuada desde a dedicatória do livro, a referência à tragicomédia aparece como melhor convém fazê-la, ou seja, de modo antitético. Dedicando a narrativa às almas sensíveis e aos que sabem transformar as amarguras em risos, o autor de antemão anuncia que se trata de uma história que despertará, simultaneamente, a comoção e o

${ }^{123}$ Ibid., p. 20. 
humor. Carregada de elementos dramáticos, a narrativa de Blest Gana transita de modo fluido entre o drama e o romance.

Com muitas ações expressas em diálogos, o romance apresenta, em diversos momentos, as estruturas do gênero dramático, mas apresenta, em contraponto, a riqueza de detalhes que é própria do gênero de costumes. Foi, justamente este, o impasse enfrentado pelos diretores de teatro Abel Carrizo e Luis Guzmán que, em $1980^{124}$, encontram no romance um forte apelo para encená-lo nos palcos chilenos, mas esbarram nos obstáculos da forma os quais dificultam as adaptações teatrais.

El Ideal de un Calavera, embora tenha um forte apelo dramático, apresenta uma variedade de detalhes em suas cenas, que oferecem barreiras para sua fiel transposição. Na peça homônima, realizada pelos aludidos diretores, percebe-se a tentativa de preservar os quadros montados por Blest Gana. Mas o que poderia ser um ganho é indicado como ponto negativo pelos críticos teatrais, que consideram a encenação muita extensa e pouco cênica, pois julgaram que seu roteiro prendia-se demasiadamente ao texto original. Nas palavras da crítica M. Eugenia Di Doménh: “Debemos decir primeramente, que la obra es muy larga para ser adaptada al teatro, en un lapso prudente. Además, la novela exige muchos cambios, lo cual en la realidad teatral (por espacio y tiempo) es difícil; casi imposible." 125

As minúcias tão preciosamente exploradas pelo narrador no romance parecem excessivas para o teatro, no qual as condições de reprodução de ambientes e cenários são mais limitadas: Nesta direção, Lukács adverte para o sentido prático e formal: “ $\mathrm{Na}$ tragédia, o menos é mais e a redução bem concatenada dos elementos básicos só tende a ressaltar as virtudes da forma.”126

Considerando as dificuldades para a adaptação dramática, evitaremos correr o risco de nos equivocarmos, ao enquadrar um romance de costumes do século XIX dentro de uma poética normativa dos gêneros, na qual a forma pré-existe ao conteúdo, posição completamente contrária àquela do romance de costumes, que guarda em sua expressão a relação inversa, cujo conteúdo tende a preceder a forma. Neste sentido, preferimos utilizar os termos, ‘trágico’ e ‘cômico’ como adjetivos, no lugar de sua

\footnotetext{
${ }^{124}$ O artigo de Jornal La Nación Domingo 26 de outubro de 1980. Material encontra-se no arquivo da Biblioteca Nacional do Chile - caixa única.

${ }^{125}$ Ibid.,.

${ }^{126}$ LUKÁCS. George. A teoria do romance. São Paulo: Editora 34, 2000. p. 206.
} 
acepção de gêneros, pois compreendemos que o trágico e o cômico não se restringem ao espaço dramático, podendo inclusive adjetivar outras formas literárias.

Ao longo da narrativa em que alguns aspectos revelam a tragicidade e outros a comicidade, o protagonista não hesita em seu papel e é, sem dúvida, um herói, sendo muitos os elementos que permitem caracterizá-lo desta forma. Conforme propõe Aristóteles em sua Poética, as tragédias devem imitar homens superiores. E é exatamente isto que vemos no romance: Abelardo Manríquez é a mais alta das figuras no romance e, em diversas oportunidades, o narrador comenta a sua distinção em relação ao vulgo restante. “Llevaba en su alma, turbulenta por la savia de la juventud, esa chispa de aspiración vaga, que solo se anida en los pechos de aquellos que nacen organizados para distinguirse del vulgo.”127 Apesar de não pertencer à aristocracia do dinheiro, resta-lhe a nobreza de coração que a família empobrecida lhe deixará de herança. Mas não exatamente trágico, nosso herói está mais envolvido em uma busca pessoal que lhe aproxima mais do típico exemplar do herói medíocre, à maneira dos heróis de Walter Scott, tal como é mostrado por Lukacs. ${ }^{128}$

Quanto ao caráter do herói trágico, as recomendações aristotélicas são: “não devem ser representados nem homens muito bons que passem da boa para a má fortuna - caso que não suscita terror nem piedade, mas repugnância -, nem homens muito maus que passem da má para a boa fortuna” ${ }^{\text {"29 }}$. Nesta medida, a ambiguidade da figura do calavera acaba garantindo que Abelardo Manríquez não seja 'nem muito bom e nem muito mau'.

Com todo cuidado, o narrador examina esta figura impar, partindo de um suposto estudo das almas que caracterizaria uma parcela das pessoas condenadas ao infortúnio. A princípio, a vinculação entre alma e sorte, implícita no comentário inicial do narrador, sugere uma relação com a noção de totalidade essencial do mundo grego, sobre a qual Lukács comenta em A Teoria do Romance, no capítulo "Culturas Fechadas”. Considerada pelos gregos como essência animadora, a alma era determinante e inseparável da existência humana. Metáfora do sopro da vida, ela representava para eles a imortalidade que, por sua vez, era prerrogativa dos grandes homens. Além do significado simbólico, a conjugação entre alma e destino remetia a um mundo homogêneo, no qual tudo se encaixava perfeitamente: "No destino que dá

\footnotetext{
${ }^{127}$ BLEST, Gana. Op. Cit. 1908 Tomo I. p. 22.

${ }^{128}$ LUKÁCS, Georg. La Novela Historica. México: Ediciones Era, 1966.

${ }^{129}$ ARISTÓTELES. Poética. Trad. Eudoro de Souza. Porto Alegre: Globo, 1966. p. 252.
} 
forma e no herói que, criando-se, encontra a si mesmo, a pura essência desperta para a vida, a simples vida aniquila-se perante a única realidade verdadeira da essência"[... $]^{130}$.

Em contrapartida, o narrador de Blest Gana toma a matéria essencial, mas considera a vida cotidiana num mundo vasto e heterogêneo. Para ele, a alma possui uma "infinita variedad de atributos para confundir la presunción investigadora y deductiva de los pensadores" ${ }^{131}$. No entanto, ele acredita que seja possível realizar um estudo das almas, sobre múltiplas e infinitas características, num novo equilíbrio que as classifica em duas principais categorias: as primeiras, que "al nacer reciben el germen de lo que serán en su transcurso por el mundo"; e as segundas, que são "como las naves en el mar, flotarán a impulsos del viento caprichoso de las circunstancias" ${ }^{132}$. Deixando as primeiras de lado, o narrador diz: "Hablemos de las últimas, porque á ellas pertenecía el alma de Manríquez”.

Nessa direção, em um tom pomposamente metafórico, o narrador subdivide a segunda categoria de almas em três grupos: Um primeiro grupo de almas que são impulsionadas por bons ventos e chegam ao porto, com suas velas quase intactas. Outras, que embora com a embarcação em farrapos, atravessam as tempestades de sua existência e ancoram vitoriosas no porto do repouso eterno. E finalmente, o terceiro grupo, no qual se enquadra mais precisamente a alma do protagonista, aquele das almas que, condenadas pelos vendavais incessantes, são combatidas por obstáculos que as impedem de completar a travessia. Náufragas, essas almas jamais chegam à outra margem:

Sus pasiones, desencadenadas en deshecha tormenta por las fortuitas circunstancias que componen el destino de todo ser humano, lanzaron ese rugido al estrellarle, rica de vigor y de juventud, contra el banco del patíbulo, en que el pueblo curioso le vió arrostrar la muerte con arrogancia impávida. ${ }^{133}$

Há, claramente, aqui uma pré-determinação de destino para cada tipo de alma, de modo a nos levar à conclusão de que, para Abelardo Manríquez, não resta outra possibilidade a não ser a de fracassar no cumprimento de sua travessia. Posto como determinante de sua própria sorte, o trágico fim do protagonista parece revelar o caráter

\footnotetext{
${ }^{130}$ LUKÁCS. George. In: Posfácio. A Teoria do Romance. São Paulo: Editora 34, 2000. p. 32

${ }^{131}$ BLEST, Gana. Op. Cit, 1908. Tomo I. p. 13.

${ }^{132}$ Ibid., p. 15.

${ }^{133}$ Ibid., p. 15.
} 
inevitável do infortúnio. No entanto, como tentaremos provar, a morte do protagonista entende-se mais à luz da busca de uma ideia fixado que precisamente de uma fatalidade trágica, daí a chave trágico-cômica na qual o romance pode ser lido.

\section{1- O RECONHECIMENTO}

O fim trágico do calavera Abelardo Manríquez não corresponde somente à tragédia no sentido clássico, pelo contrário, há nele um comportamento quixotesco que transforma o ideal em uma busca, se não irreal, pelo menos, impossível de tornar-se realidade. Ser um amante cortês em plena primeira metade do século XIX, na recémindependente nação chilena, que nesses tempos imaginava se modernizar à moda e os costumes europeus, configura uma situação comparável ao anacronismo do cavaleiro andante Dom Quixote. Toda esta situação agrava-se ainda mais pelo engano do calavera que não percebe em sua amada, Inés Arboleda, a preferência pelo dinheiro e não pelo amor.

A passagem do estado da dita para a desdita é dada aqui por meio do reconhecimento. O reconhecimento é, segundo Aristóteles, um dos elementos mais importantes para a composição de uma boa tragédia. No caso do drama de Abelardo Manríquez, já mencionamos que o momento do reconhecimento dá-se quando ele descobre o coquetismo de Inés, qualidade que o narrador afirma compor o real caráter da personagem. Embora não respeite exatamente os preceitos aristotélicos de um reconhecimento clássico o qual poderia ser, grosso modo, exemplificado por um sinal no corpo, como uma cicatriz; ou por um elemento externo, como um objeto pertencente à personagem, ou lembranças retiradas da memória depois de anos de distância; ou através de uma estrutura de raciocínio dedutivo. Vale lembrar que todas essas possibilidades podem, ou não, estar associadas a uma peripécia.

O reconhecimento na obra de Blest Gana perde o sentido clássico e aproxima-se do sentido subjetivo da tragédia moderna proposta por $\operatorname{Hegel}^{134}$, segundo a qual a

\footnotetext{
${ }^{134}$ Ver HEGEL, Georg Ludwig Friedrich. Curso de estética: o sistema das artes. São Paulo: Martins Fontes, 1997.
} 
subjetividade do sentimento de Abelardo Manríquez aceita o reconhecimento em uma acepção menos denotativa e mais conotativa. Trata-se, na realidade, de uma constatação daquilo que já estava às claras. Irônico, este reconhecimento ao mesmo tempo em que causa terror e piedade também pode ser considerado cômico. A comicidade se estabelece justamente pelo fato de Abelardo Manríquez não reconhecer em Inés aquilo que o narrador aponta desde um início e que é exaustivamente demonstrado pelas inúmeras observações e digressões que ele imprime em sua forma de narrar.

Ao leitor não restam dúvidas quanto ao comportamento coquete de Inés. Sabemos a todo momento que ela não corresponde aos sentimentos do jovem e que sua intenção é casar-se com o rico pretendente, José Miguel de Sendero. Porém, mesmo o leitor já conhecendo o engano que comete Abelardo Manríquez, o relato da descoberta do dito real caráter de Inés provoca um misto de piedade e comicidade que apresenta uma alta complexidade interpretativa.

Estrategicamente arranjada à narrativa, a peripécia que conduz Abelardo Manríquez a seu infortúnio ocorre na primeira parte do livro, mas é deixada em suspense por toda a segunda parte para apenas ser retomada na terceira. Atravessando este espaço temporal, a revelação óbvia de que ele não é correspondido por Inés Arboleda fica sem esclarecimentos explícitos, mas subentendida.

Recuperado na terceira parte, o desfecho do rapto da jovem Inés Arboleda é precisamente o momento do reconhecimento e, contudo, nesta retomada quem narra é o próprio Abelardo Manríquez. O narrador entrega a voz ao protagonista para que ele mesmo possa explicar ao amigo Felipe Solama a sua má conduta com Candelaria. Transgredida a função primeira do reconhecimento trágico de passar da boa para a má fortuna, a peripécia é utilizada antes como justificativa do que como desenlace.

A comicidade provocada pelo fato do protagonista reconhecer aquilo que somente ele não enxergara até esse momento perde aqui um pouco sua força com a mudança do foco narrativo. Sem o narrador para manter uma distância irônica, como no relato dos fatos na primeira parte do romance, Abelardo Manríquez conduz agora a narrativa, com intenção de convencer o amigo e também os leitores da legitimidade de seu distanciamento de Candelaria. Embora os argumentos do calavera não cheguem a convencer Felipe Solama a desistir de armar um reencontro do casal, formalmente eles 
produzem um efeito de inversão que coloca em segundo plano o valor cômico para dar lugar à piedade. De modo que, através do relato de Abelardo Manríquez, enxergamos esta personagem mais como vítima da coqueteria de Inés do que como a razão de escárnio.

Nesse sentido, é importante alertar que o narrador cede a voz, mas permanece escondido dentro do discurso do protagonista. Com efeito, há uma supervisão da narração, por meio do discurso indireto livre, que aparece explicitamente, controlando a fala do calavera: "Yo era niño entonces, sobre todo para el corazón: era la primera vez que amaba, dijo Manríquez después de un ligero silencio.” ${ }^{135}$. Reparemos que, neste trecho, há uma intromissão do narrador que finge se distanciar do relato de Abelardo a Felipe, mas marca sutilmente sua presença como porta voz da conversa entre os amigos. Em meio a estes dois planos narrativos, o narrador que parece conceder, na realidade continua a controlar as personagens.

Sem abrir mão da onisciência, este narrador concede a palavra à personagem como uma medida conciliadora entre os argumentos cômicos e os trágicos. Dividindo a tarefa de narrar, ele consegue, por um lado, um efeito de distanciamento e, por outro, apresenta uma incapacidade de explicar satisfatoriamente a ambiguidade do seu próprio protagonista. Igualmente ambíguo, o narrador burla-se de Abelardo Manríquez e, ao mesmo tempo, que lhe tem apreço, de tal forma que seu discurso indica a heroicidade do calavera, mas não deixa de ressaltar os aspectos cômicos de sua figura.

Ainda que não seja ridicularizado abertamente pelo narrador, como acontece com o cavaleiro andante da triste figura, Abelardo Manríquez sofre a pressão social que não encontra em sua nobreza de coração o valor monetário que deveria acompanhá-la. Neste sentido, o narrador dá voz aos confusos pensamentos de Inés que, depois de um longo momento de meditação, conclui: “-iAh, si el rico fuese Manríquez!” ${ }^{36}$. Este pensamento, de algum modo, vem confirmar que o conflito do jovem Abelardo é antes financeiro do que amoroso. Pois seu infortúnio parece ter uma ligação com o já aludido liberalismo conservador chileno, que ideologicamente pensa uma sociedade liberal, mas que à risca recrimina a mobilidade social.

\footnotetext{
${ }^{135}$ BLEST, Gana. Op. Cit. 1908. Tomo II. p. 39-40.

${ }^{136}$ BLEST, Gana. Op. Cit. 1908. Tomo I. p. 82.
} 
Doris Sommer, em seu livro Ficção de Fundação ${ }^{137}$, faz um arrolamento dos considerados principais romances de fundação das nações latino-americanas, pensando nos pares românticos que os protagonizam como uma conciliação liberal, cujos casamentos entre diferentes classes simbolizariam o trânsito social. Seguindo esta linha de análise, a pesquisadora acredita que, no romance Martín Rivas de Blest Gana, o encontro de classes está representado pela união do casal Leonor Encina e Martín Rivas, o qual sugere a entrada deste último à “aristocracia chilena”. Contudo, Laura Hosiasson ${ }^{138}$ aponta que esta mobilidade é antes uma retomada de uma posição social perdida, uma vez que boa parte da fortuna da família Encina teria sido usurpada da mina do pai de Martín Rivas, desse modo o jovem apenas resgata aquilo que por direito já lhe pertenceria.

Mesmo em outros romances do escritor, a mobilidade social, por meio do casamento, não chega a se concretizar. Em La Aritmética en el amor, Fortunato Esperanzo acaba rejeitado pelas jovens dos salões aristocráticos. Enquanto o indígena Fermín Mariluán, protagonista do romance Mariluán, é sumariamente impedido de estabelecer uma união com uma jovem branca.

Considerando que as especulações amorosas amarram a tônica de muitos dos romances de Blest Gana, não poderíamos deixar de notar que, em El ideal de un calavera, as relações financeiras estão entrepostas entre as diversas personagens. Tanto é assim, que na composição dos dois triângulos amorosos, que movimentam a trama, cada um deles carrega em um de seus lados o atrativo monetário. Inés Arboleda escolhe o rico pretendente Miguel de Sendero, já Candelaria a princípio elege o amor, mas se sentindo sozinha e abandonada por Abelardo Manríquez, rende-se aos luxos oferecidos por Don Lino Alcunza que, como veremos, concentra no dinheiro o seu único encanto.

${ }^{137}$ Ver SOMMER. Doris. Fiç̧ão de Fundação. Belo Horizonte: Editora UFMG, 2004.
${ }^{138}$ HOSIASSON. Laura. Op.cit, 2004, p. 240-245. 


\section{2 - Don Lino Alcunza Calavera SÊNior}

Abelardo Manríquez apresenta o valor de honra de um verdadeiro herói trágico. Ainda que no contexto representativo da obra não seja socialmente nobre, sua superioridade diante dos outros homens impede-lhe que venha a ser objeto de escárnio, mesmo quando protagoniza cenas cômicas. Sendo este papel principalmente desempenhado pelo seu rival, Don Lino Alcunza, quem é alvo a todo o momento das mais diversas brincadeiras e peças pregadas por Abelardo Manríquez e seus amigos. Para compreendermos melhor a função dada a Don Lino é importante que antes nos aproximemos de sua composição.

A Don Lino Alcunza faltam quase todas as qualidades atribuídas ao jovem herói. A personagem é introduzida na segunda parte da obra, intitulada "Los Calaveras”, juntamente com outras personagens que passam a integrar a história de Abelardo Manríquez. A aparência física desgastada de Don Lino é a primeira indicação de sua comicidade, e ao invés de descrevê-lo diretamente, o narrador constrói uma imagem que o ridiculariza:

Don Lino se había lanzado a merodear al florido campo de Venus, interponiendo la mediación de su dinero, ya que de atractivos personales los años le habían robado el usufructo. Y esto decimos, porque don Lino Alcunza no peinaba ya propio, sino ajeno cabello, $y$ había perdido la juventud de su mirada como la frescura del cutis y la desenvoltura que tiene el cuerpo, antes que las trabas de los muchos años le entorpezcan. ${ }^{139}$

O caráter ridículo, que predomina em sua aparência física, também se estende a suas atitudes morais, conforme a regra clássica da composição das personagens. No extremo oposto a Abelardo Manríquez, o velho rico e sem nobreza, demonstra em todo momento sua falta de índole com ações baixas que permeiam seu comportamento. A menção de Fígaro, na dedicatória do romance, não deixa dúvidas de que os vícios da personagem foram inspirados na descrição da casta dos velhos

${ }^{139}$ BLEST, Gana. Op. Cit. 1908 Tomo I. p. 160. 
calaveras que perseguem as jovens belas, feita pelo cronista Mariano José Larra . Enfim, a comicidade da personagem ajusta-se perfeitamente à sua figura.

Don Lino Alcunza disputa com Abelardo Manríquez o coração de Candelaria, mas nem sequer representa um obstáculo para o jovem, pois todas suas investidas para afastá-lo dela são facilmente revertidas pelo herói. Engenhoso, ele arma planos mirabolantes com o auxílio dos amigos calaveras, Felipe Solama e Francisco Timoleón Miraflores. Essas investidas, além de aproximá-lo mais ainda da jovem, também servem para zombar de seu oponente.

Muitas são as ocasiões em que Don Lino é feito de bobo, sendo ridicularizado até mesmo quando está ausente. Ao início da segunda parte, quando o narrador nos apresenta as personagens que terão fundamental importância nesta parte da narrativa, todas estão reunidas, saindo em comitiva para a casa de Don Cayetano Alvorada, parente de Don Raimundo Basquiñuela, onde irão se encontrar com Abelardo Manríquez.

Essa parte da obra separa-se da primeira por ser exclusivamente ambientada em espaços frequentados por gente de medio pelo e, em consequência, traz muitas personagens que se configuram como os mais caricatos representantes dessa parcela da sociedade chilena. Aproximando-se aqui também daquilo que a poética aristotélica caracteriza como estrutura da comédia "imitação de homens inferiores; não, todavia, quanto a toda espécie de vício, mas só quanto àquela parte do torpe que é ridículo." ${ }^{140}$ Assim, temos neste quadro o cenário propício para a construção de passagens cômicas que a partir deste momento passam a povoar a narrativa.

Na casa de Don Cayetano Alvorada se dá uma das cenas mais cômicas, cujo centro não poderia deixar de ser Don Lino Alcunza, colocado mais uma vez como alvo de zombaria. Os jovens calaveras convencem o velho, embalado pelo álcool, a aproveitar-se da oportunidade em que Candelaria está dormindo no quarto ao lado, para dar-lhe um amoroso abraço. Com o auxílio das irmãs Basquiñuelas, criam uma confusão que acaba com Don Lino abraçando a Don Raimundo. Além de lembrar sobremaneira algumas das cenas hilárias em que Don Quixote é submetido a vexames envolvendo as dueñas das vendas, claramente, nesta e em outras cenas, Don Lino Alcunza parece ser um fantoche nas mãos dos jovens calaveras. O que nos remete à forma de comicidade, pela qual "uma personagem acredita estar falando e agindo

${ }^{140}$ ARISTOTELES. Op. Cit. p. 245. 
livremente [...], mas que, vista de outro lado, aparece como simples joguete nas mãos de outra, que com isso se diverte." 141

Mais um recurso utilizado a favor da comicidade é o proveito do medo para causar o riso. Esta situação ocorre em plena encenação da comemoração do nascimento de Cristo, o que representa uma dessacralização da comemoração religiosa. A festa acontece na casa de Doña Antonia, que surge na história apenas como um elemento para o reencontro dos calaveras com as irmãs Basquiñelas as quais, por armação de Don Lino Alcunza, ficaram proibidas de receber a visita dos jovens. A trapaça é articulada para distrair a atenção de Don Lino que orienta Don Raimundo a afastá-los das filhas.

Miraflores escondido atrás das cadeiras em que se acomodam os opositores costura as pontas das roupas deles aos que ocupam os assentos ao lado para impedir que eles se levantem na hora em que Manríquez e Solama anunciam um suposto tremor. Em meio ao caos, causado por essa notícia catastrófica, os amigos encontramse tranquilamente com as jovens.

O efeito cômico da anunciação do tremor deve ser compreendido em contexto com o advento periódico de tremores e terremotos no Chile, para os quais a população está sempre preparada. Diante deste medo compartilhado, os gritos que anunciam o tremor, facilmente se multiplicam e, antes mesmo de constatar se realmente a terra se movimenta ou não, todos saem em busca de abrigo; o automatismo da ação é que garante a comicidade. Esta cena por si só já provoca o riso, mas ganha mais graça com Don Lino costurado de um lado a um padre e de outro a escandalosa Doña Dolores, esposa de Don Cayetano que, por sua vez, está costurada a Don Raimundo.

Antes da cena cômica, o narrador tem o cuidado de chamar nossa atenção para a importância que a apresentação de nascimento de Jesus representava entre as camadas mais populares da época em que transcorre a história. Montado este quadro de costumes, o narrador afasta-se do tempo da matéria narrada e constrói, conforme as palavras de Guillermo Gotschlich Reyes, uma alegoria humorística:

"que se constituye como unión de lo incojugable, quiebre ridículo de la desigual composición que intenta con afán prosaico, subsumir la 'verdad' del mundo, dando lugar a la sátira grotesca que anima la

${ }^{141}$ BERGSON, O Riso - Ensaio sobre a significação da comicidade. Tradução Ivone Castilho Benedetti. São Paulo: Martins Fontes, 2000. p. 57. 
creación del retablo y la situación conjunta de la escena novelesca" $[. . .]^{142}$

Ainda nos restam outras cenas cômicas que mereceriam ser mais detalhadamente analisadas, mas para evitar o risco de tornar a análise repetitiva, apenas mencionaremos os recursos utilizados, deixando de lado os seus pormenores. Também nos chama a atenção a passagem em que as personagens vão ao teatro assistir a um sainete, peça divertida de caráter popular com um ou mais atos independentes. Nesta circunstância, a ida ao teatro proporciona cenas hilariantes, promovidas pela ambientação 'costumbrista', que nos apresenta o narrador, ou pela divertida interação das personagens, as quais passam a integrar a encenação, de tal forma que platéia e palco parecem formar uma única apresentação.

O riso nesse caso é provocado por dois procedimentos muito comuns nas comédias. O primeiro é o equívoco cometido pelo ator da peça que interpreta San José, e declama seu monólogo trocando as letras “s” pela letra “f”. O narrador anuncia o equívoco dizendo que, provavelmente, o ator extraiu o monólogo de uma edição antiga com problemas tipográficos, impedindo que o público compreendesse a encenação. Felipe Solama é o único que percebe o erro do ator e, em tom de gracejo, diz: “-Señor Fan Jofé, nadie entiende lo que ufted eftá deciendo". ${ }^{143}$

O ator, indignado com o comentário de Felipe, paralisa o monólogo e, em uma linguagem bem coloquial, responde: “-Amuélate si no entendis, así está la pieza, futre encolao." ${ }^{144}$, o que provoca as mais diversas reações na plateia. Com o estado de ânimo alterado, o intérprete de São José acaba mudando a serenidade das palavras do Santo e, em meio a este engraçado espetáculo, abandona o palco, mas a cortina que ia se fechando prende-se no bastidor e continuamos assistindo a fúria da personagem.

A cena aqui rapidamente descrita é motivo de riso para leitor que se deleita ainda mais ao ver a fictícia plateia entregar-se também ao riso. A hilaridade desse quadro está no equívoco, um efeito cômico utilizado desde as comédias latinas ${ }^{145} \mathrm{e}$ que garante, até os dias de hoje, a diversão do público.

No entreato, os jovens calaveras Abelardo Manríquez e Felipe Solama convidam Don Lino e Don Cayetano para conhecerem as bailarinas. Os dois velhos

\footnotetext{
${ }^{142}$ GOSTCHICL. Reyes Guillermo. “Grotesco y tragicomedia en El ideal de un Calavera”. In: Revista Chilena de Literatura, ${ }^{\circ} 29$ Abril, 1987- p. 135.

${ }^{143}$ BLEST, Gana. Op. Cit. 1908 Tomo II. p. 86.

${ }^{144}$ Ibid., 87.

${ }^{145}$ Ver BERGSON. Op. Cit.
} 
vão muito animados até os bastidores, mas acabam sendo vítimas de mais uma farsa armada pelos jovens, que combinam com as bailarinas para distraí-los. Enquanto os velhos tentam conquistar as bailarinas, os calaveras levantam a cortina e o público surpreende o espetáculo dos 'galãs', que fogem ao se darem conta do ocorrido. A situação ridícula em que se encontram Don Lino e Don Cayetano é provocada pela dissimulação, comumente usada nas peças cômicas para enganar e burlar as personagens.

\section{3- CALAVERA - TiMOLÉON MIRAFLORES, O HOMEM DOS QUINZE RAPTORES DE CANDELARIA}

Timoleón Francisco Miraflores também é uma personagem cômica, mas diferente de Don Lino Alcunza, sua comicidade está mais construída em seu próprio discurso do que em elementos físicos. Para descrever pela primeira vez a sua figura, o narrador foge do procedimento adotado com as demais personagens e não relaciona sua aparência física ao seu caráter moral. Miraflores é brevemente descrito como um homem de trinta anos a quem a adjetivação do substantivo parola é segundo o narrador a expressão que melhor o caracteriza.

No latim, parola significa palavra - mas em espanhol ganhou o sentido de “fala”, “discurso” - na acepção, utilizada pelo narrador, tem a conotação de “lábia”, que, popularmente, sugere que Miraflores seja um contador de vantagens, tendo mais astúcia na fala do que nas ações. Conjugados a esta caracterização, podemos também perceber na construção de sua figura dois elementos que, de acordo com as análises de Bergson, são marcas recorrentes em personagens cômicos: o exagero e a covardia. Comicamente arranjados, estes argumentos parecem aqui como complementares, de forma que o primeiro serve para esconder o segundo.

A hilária passagem que marca esse comportamento cômico é a cena do resgate de Candelaria que resulta no enfrentamento dos amigos calaveras com os soldados os quais Don Lino Alcunza enviara para sequestrar a jovem. Pela porta principal chegam três soldados que, em uma luta corporal, distraem Felipe Solama e Abelardo Manríquez. Enquanto isso, pela porta dos fundos, por onde fugia Candelaria, protegida por Timoléon Miraflores, aproximam-se mais dois soldados que facilmente 
o rendem e a levam. Se de um lado temos a resistência de verdadeiros heróis na entrada principal, no lado oposto da fachada, vemos a piedosa cena de Miraflores de olhos vendados, apavorado de medo, aguardando passar o tempo determinado pelos raptores para desvendar-se.

Surpreendido por Solama, o covarde Miraflores recompõe-se, tentando ganhar tempo para inventar uma justificativa que amenize a vergonhosa situação na qual se encontrara. Apelando a pensamentos fantasiosos, soma mais treze ao número de soldados que lhe renderam e relata um falso embate do qual Manríquez e Solama, já conhecendo sua falta de valentia, logo desconfiam. As dúvidas sobre os exageros da história são confirmadas quando estes reencontram Candelaria. Ainda assim, Miraflores, mesmo com os escárnios dos amigos, continua jurando que foram quinze os raptores da jovem.

Mesmo se tratando de um contador de vantagens, Miraflores não é propriamente um mau caráter, pelo contrário é um calavera do tipo gozador, irreverente e amante da farra. Com o mesmo exagero que lhe é peculiar, ele transita entre os mais variados ambientes chilenos, soltando rojões e contando suas aventuras. Alegre e expansivo, uma de suas principais funções na narrativa é a de ser o intermediador das várias camadas sociais. Filho desgarrado da aristocracia santiaguina, promove o ingresso do protagonista Abelardo Manríquez na festa da alta sociedade chilena em homenagem a Inés Arboleda com a mesma facilidade que o introduz no ambiente de medio pelo.

\section{4-Felipe Solama Calavera de BUEN TONo}

Blest Gana já havia anunciado ao amigo José Donoso que a maior parte das cenas e dos tipos de El ideal de un Calavera seria retirada da realidade. Talvez seja por isto que Lastarria sugerira que o autor teria se espelhado em alguma figura específica para compor Felipe Solama, mas o escritor nega: "Si hubo algo, en la idea primitiva de Benicio, creo que dejé de tejas abajo y me fui con Solama a regiones donde aquél no llega ni há pretendido llegar. Tal vez tenga el corazón de Felipe; pero le niego su chispa.”146 Esta carta foi enviada ao amigo Lastarria em 25 de janeiro

\footnotetext{
${ }^{146}$ FERNANDEZ. Larraín. Sergio p. 56
} 
1864. Não podemos saber ao certo a quem se referem pelo nome de Benicio, porém podemos inferir que, apesar de Blest Gana lhe negar o espírito, o mesmo não se pode dizer da crônica de Larra, da qual claramente retira a inspiração para a construção do calavera letrado, descrito pelo cronista como calavera de buen tono.

Como já referimos, o ambiente do medio pelo é o mais propício para as cenas de humor, entretanto a comicidade não se limita a este espaço. Na festa em que Abelardo Manríquez vai ao encontro de Inés Arboleda, o narrador descreve com cuidado os detalhes do quadro, o qual remontaria aos bailes da aristocracia santiaguina daquela época para o seu leitor contemporâneo. Sempre marcando a distância temporal, o narrador parece parodiar os primórdios da civilização chilena, enfatizando que nestes tempos era comum, algumas caleças serem puxadas por mulas e não menos estranho a chegada de convidados a pé, apontando também a deselegância da anfitriã que, com um decote extravagante, destaca a robustez de suas formas.

Somado ao retrato que desenha o narrador, Felipe Solama esboça uma divertida caricatura da alta sociedade. Ao lado de Manríquez, ele transita pelos espaços da festa e reconhece os tipos masculinos que costumam frequentar os bailes da elite. Vale a pena destacarmos nesta passagem o recurso cômico utilizado para realizar uma crítica ao cenário social chileno. Através de um humor mais refinado e característico da Comédia Humana de Balzac, Solama transforma homens de suposta distinção em tipos sociais que se relacionam ironicamente com o contexto histórico.

Segundo a divisão que nos propõe, existem os bobos graves, os satisfeitos, os simples e os desagradáveis. Os graves, ele descreve como aqueles que não têm opiniões próprias e, exatamente por isto nunca se comprometem. O narrador insinua que dão ótimos políticos e conselheiros por nada aconselharem. Referindo-se à postura conservadora, afirma que conservam as velhas modas, velhas ideias e velhos assuntos. Acusa-os de ter pavor dos livros, indicando assim a sua ignorância e a daqueles que os seguem. A comicidade aqui conseguida é resultado de uma perspectiva liberal que ridiculariza os ideais conservadores, transferindo como num processo metonímico a posição de manutenção da ordem econômica colonial para as características intelectuais e físicas daquele que segue os ideais conservadores, dandonos a impressão de seus gostos antiquados.

No outro canto do salão, aponta o grupo dos bobos satisfeitos que, de acordo com sua percepção, são como jóias falsas que reluzem um valor que não têm. Falam alto, criticam sem compaixão, olham com desprezo para os que estão mal vestidos, 
creem-se superiores e capazes de escrever grandes obras. Só as altas quantias lhes interessam. Também são frequentes as referências de suas viagens para Europa ou dos sonhos que estas figuras nutriam para conhecer o velho continente. A crítica a estes 'elegantes’ é recorrente na obra de Blest Gana, Agustín Encina, personagem de Martín Rivas, é um dos mais hilários representantes desse tipo social em seus romances.

Já os bobos simples são, para ele, ecos dos satisfeitos. Multiplicam-se rapidamente, devastando os ambientes sociais com sua habitual superficialidade; importam-lhes mais os trajes do que estudos, amores e políticas. E, finalmente, nos apresenta os bobos desagradáveis que, apesar do bom coração, são pegajosos como mel, perseguem os convidados por todas as partes, sendo sempre amáveis e de sorriso forçado. Entre os bobos estes são os de caráter mais cômico, pois ignoram o seu defeito e pensam-se simpáticos e agradáveis.

As reflexões de Felipe Solama sobre a sociedade são prato cheio para buscar a representação do meio social, assim como sua própria figura, também coloca em cena um tipo que, para José Victorino Lastarria, suscitava mais apreço do que o protagonista Abelardo Manríquez. A preferência pelo advogado foi revelada na já mencionada carta de Blest Gana a Lastarria, em que o escritor comenta as observações do amigo ex-ministro sobre o romance e as personagens ${ }^{147}$. Em destaque, ele confessa que não o esperava popular, acreditava que Felipe Solama seria apenas uma personagem saborosa para inteligências delicadas.

Nesse sentido, Blest Gana refere-se ao discurso empolado de Felipe Solama que abusa de citações mal empregadas, sendo tomadas, algumas vezes, como sérias para os leitores mais desatentos. Construída de maneira paródica, a composição desta simpática personagem traz à cena a figura de fácil elocução que representa um pseudo-pensador das grandes questões filosóficas e sociais. De maneira irônica, o narrador sinaliza que, embora ele tenha bons dotes intelectuais, estes seguem em direção errada, porque apesar de cultivar o gosto pela leitura, o faz sem muita ordem nem propósito fixo.

As inúmeras leituras desordenadas de Felipe Solama constroem uma personalidade que traz camuflada em suas reflexões a comicidade, da qual ele é, ao mesmo tempo, o investigador e o objeto. Em meio a uma salada de ideias e frases de

147 As opiniões de Lastarria sobre a obra El ideal de un Calavera ficam restritas à correspondência ativa de Blest Gana. 
diversos autores, ele é, por um lado, o porta-voz das críticas à sociedade representada no romance - chegando algumas vezes a complementar as digressões construídas pelo narrador - e, por outro, é o representante do mau leitor, que no afã de fazer-se culto perde-se em meio a leituras desconexas.

O ponto alto das reflexões de Felipe Solama está na sua teoria da almas huérfanas, cujo princípio, como explica o narrador, vem da tendência do advogado de buscar fins importantes em ações vulgares. Solama investiga as almas que, segundo sua sistematização, pertenceriam à família das almas órfãs, e não por acaso, elege Abelardo Manríquez como a figura de destaque.

Sem grandes fundamentos, a teoria das Almas huérfanas é superficialmente apresentada na narrativa, Felipe Solama é praticamente interrompido em quase todas as tentativas de esboçá-la, o que demonstra certa ridicularização de suas elucubrações sobre a teoria, com a qual espera projetar o seu nome para posteridade.

Nesse sentido, o pouco que sabemos sobre a teoria, é que se apóia na figura romântica do indivíduo incompreendido, conforme tenta nos explicar: “- Por mi parte, contestó Felipe, yo soy supersticioso como Rousseau, lo que me induce a creer que esa vaga superstición, que tiene gran afinidad con el fatalismo, es propia de las almas huérfanas”148. Desconexos, seus argumentos parecem mais confundir do que explicar, e tentando forjar uma confiabilidade, cita um nome de autoridade como Rousseau, porém atribuindo-lhe um significado vazio.

Além desse problema teórico, temos também um de ordem metodológica que o próprio Felipe Solama deixa claro quando comenta a respeito de suas ideias: “Desgraciadamente, la fórmula para reconocer las almas huérfanas por medio de las manifestaciones exteriores, es todavía un problema para mí, y sin esto mi gran teoría quedará incompleta". ${ }^{149} \mathrm{O}$ problema de reconhecimento das almas é ironicamente tratado pelo narrador, antes mesmo que a teoria de Felipe Solama entre em cena. Antecedendo a sua já mencionada classificação das almas, o narrador, em tom de deboche, alerta para a variedade de atributos de cada alma que, certamente, confundirá a presunção investigadora e dedutiva dos pensadores.

Depois de conhecermos o impasse da teoria de Solama, temos indícios que nos permitem pensar que o comentário do narrador é uma referência à problemática metodologia da teoria defendida pelo advogado. Sendo pouco provável que se trate

${ }^{148}$ BLEST GANA, Op Cit. 1908 Tomo I pp. 297-298.

${ }^{149}$ Ibid., p.298. 
apenas de uma caprichosa coincidência entre a teoria das almas huérfanas de Felipe Solama e as digressões do narrador sobre as almas.

Ambivalente e não muito clara, a conexão entre a passagem e a duvidosa teoria do jovem advogado apresentam uma origem ficcional comum que parece, por um lado, coincidir em algumas ideais que se insinuam complementares, e, por outro, sugerir a ridicularização da personagem pelo narrador.

A suposição em favor dessa conexão considera que os dois possíveis estudos partam de uma visão determinista, segundo a qual o infortúnio do protagonista estaria relacionado a um destino pré-existente. Tanto o narrador como Felipe Solama buscam razões que comprovem estar Abelardo Manríquez condenado de antemão à fatalidade. Com efeito, ainda que seja notória a forma com que o narrador zomba da personagem, a teoria de Solama auxilia o narrador para confirmar seus fundamentos quanto à sorte de Abelardo Manríquez e vice-versa.

Nesse sentido, o narrador se utiliza do expediente da teoria das almas da personagem para poder expressar-se com mais espaço e poder dentro da narrativa. Quando fala da má sorte do calavera, pela boca do advogado, mantém um distanciamento que forja a existência de outro texto que sugere uma investigação paralela à sua, que mesmo carente de confiabilidade, continua confirmando a autenticidade da história.

Além de criar uma ilusão de que a narrativa não é o único texto que se debruça sobre a vida do protagonista, o artifício empregado parece também colocar em destaque a autoridade e seriedade do relato do narrador, em detrimento do de Felipe Solama, que sempre aparece ridicularizado. Dado efeito é armado pela particularização de cada relato, como se ambos não tivessem uma filiação ficcional comum.

A sobreposição dos textos é dada, propositalmente, de maneira desigual, a respeito da teoria das almas huérfanas, como já alertado, conhecemos apenas reduzidas informações agregadas às empoladas falas de Felipe Solama e intervenções de segunda mão, embaladas por bromas e gracejos de Timoleón Miraflores e Abelardo Manríquez. Esta forma de apresentação dá a impressão de certo afastamento por parte do narrador que em poucas ocasiões a menciona diretamente.

No quinto capítulo da parte final do romance, a voz do narrador se apaga completamente e a narrativa passa a ser conduzida pela correspondência trocada por Abelardo Manríquez e Felipe Solama. Neste momento, o oficial está recluso 
aguardando o julgamento, por participar do motim liberal contra Portales. Através destas cartas, temos um panorama geral dos acontecimentos que, paralelamente, seguem o curso da trama e também do que poderíamos chamar de últimas reflexões do calavera.

Num misto de ironia e comoção, Abelardo Manríquez, prevendo sua condenação fatal, parece escrever nas missivas, enviadas ao amigo, uma espécie de revisão final, na qual se compadece com a sorte que esperará Candelaria, mas sem com isto se arrepender de sua preferência por Inés Arboleda. Também recorda o tema das almas huérfanas, estranhando a seriedade de Felipe Solama, indaga-lhe sobre quais seriam os avanços de sua famosa teoria, provavelmente, já pensando a relação que este faria com o desfecho de seus sucessos: ¿Qué hay de tu famosa teoría sobre las almas huérfanas? La mía, que resumió sus aspiraciones en salir de la orfandad, dejará este mundo en que la ventura le fué siempre esquiva, sin tener mucho que agradecerla." 150

Abelardo Manríquez reconhece-se objeto da teoria de Solama, mas parece desejar dar também suas próprias explicações para sua morte. Nesta direção, pontua que não será o primeiro homem a morrer sem cumprir seu desejo, pois vem de família em que os homens são escravos de ideias fixas, sendo bisneto de um homem que tinha a mania dos relógios, que morreu sem descobrir uma forma de fazê-los funcionar sem lhes dar corda e neto de outro que deixou a vida sem uma combinação para ganhar os montes. De modo que, Manríquez encontra na sua própria ascendência familiar uma má sorte hereditária, que o resigna a aceitar o futuro que lhe espera.

Contudo, a batalha de Abelardo Manríquez não é menos insana do que a de Dom Quixote contra os moinhos de vento, já que acreditando em um mundo heróico, quis distinguir-se do vulgo, buscando um sentido maior para sua existência, que, mesmo ante a morte, ele continuará perseguindo: “En la vida me esperaba el problema de encontrar a mi ideal: en la muerte me esperará la imortalidad." "151 É claro o desejo do calavera de fazer-se imortal. De modo que supomos ser à vista de deste anseio que o oficial de húsares estimula o amigo a seguir com a teoria das almas huérfanas, pois sabe que nela ele encontrará seu nome estampado.

Reforçando, essa hipótese da imortalidade, Manríquez em sua última carta pede abertamente a Felipe Solama que cuide de sua memória. Ilustrar as páginas de uma

${ }^{150}$ BLEST, Gana. Op. Cit. 1908. Tomo II. p. 337.

${ }^{151}$ Ibid., 338. 
famosa teoria filosófica poderia ser um fim digno de um verdadeiro herói, se não fosse o autor um extravagante leitor, com pouca capacidade de discernimento e adepto a generalidades e disparates.

A dramática morte parece não restituir o valor trágico que espera Abelardo Manríquez. No último capítulo da obra, o narrador dá forma a um breve relato dos acontecimentos após a morte do calavera, no qual registra um fim nada glorioso para o nosso protagonista. Advogando em causa de sua memória está Felipe Solama que, entre suas tagarelices, dedica ao infortunado amigo uma menção especial em sua esperada obra Almas Huérfanas, que como o narrador da conta ironicamente, "nunca há visto a luz pública".

O narrador também registra que, ao dia seguinte à condenação do jovem calavera, Inés Arboleda, para provar que não se comove com o fuzilamento de seu admirador, comparece ao lado de seu marido José Miguel de Sendero a um baile da alta sociedade. A postura fria de Inés diante da morte de Abelardo Manríquez contrasta parodicamente, com a figura da Heloísa do século XII, que nem mesmo a morte pôde separar de seu amante Pierre Abelardo. Nesta direção, percebemos que Abelardo Manríquez fracassa duplamente: durante a vida frustra-se com sua quimérica ideia fixa de encontrar no mundo a sua Heloísa e na morte aposta sem êxito na imortalidade que o colocaria ao lado dos grandes heróis. 


\section{CONSIDERAÇÕES FINAIS}

Inevitavelmente, teremos que fazer agora algumas observações mais definitivas, tarefa não muito fácil para um objeto de estudo tão marcadamente antitético. O romance que apresentamos nestes três capítulos da dissertação revela mais do que uma personagem ambígua como pensávamos a princípio. Arriscamos dizer que há mais ambiguidade na forma e nas contradições do narrador do que no próprio protagonista Abelardo Manríquez.

Tentando acomodar essas contrariedades, El ideal de un calavera atualiza o prosaísmo da saga do pobre herói que se apaixona pela jovem rica, instaurando desta maneira, desdobramentos que são manipulados em benefício de resultados mais significativos. Neste sentido, repetidas vezes acentuamos que a relação intertextual com a Correspondência de Abelardo e Heloísa interpõe-se na trama do amor não correspondido de Abelardo Manríquez por Inés Arboleda, problematizando assim o amor idealizado como elemento central da narrativa.

A idealização amorosa desencadeia o enredo que se inicia e termina em morte, num percurso circular principiado e finalizado em torno do mesmo acontecimento. A narrativa desenvolve-se alternando quadros sociais impulsionados pela tragicidade e pela comicidade. Dentro desta perspectiva, nossa análise leva a crer que o hibridismo dos gêneros apresenta-se como uma solução formal para o conteúdo contraditório da matéria do romance e, de igual modo, serve para acomodar a arbitrariedade do titubeante narrador que oferece e retira sua confiabilidade.

A famosa formulação que faz Adorno sobre “forma é conteúdo social sedimentado" ${ }^{152}$, aponta para o que já havíamos ensaiado no primeiro capítulo sobre as tendências realistas de Blest Gana que, envolvido na construção de uma literatura nacional, empenha-se em retirar da vida cotidiana os enredos para os seus romances. No caso particular de El ideal de un Calavera, o autor anunciou o cuidado especial que tomou para que nesta obra a relação com o meio social fosse mais bem representada por

${ }^{152}$ Ver ADORNO, W. Theodor. Notas de Literatura I. Trad. e apresentação Jorge de Almeida. São Paulo: Livraria Duas Cidades/Editora 34. 2008 
suas personagens e quadro de costumes ${ }^{153}$. De fato, percebemos investidas em tipos e situações caricaturais que se revestem do adjetivo nacional, não querendo com isto precisar ao certo, se Blest Gana calculou as contrariedades e incoerências que viriam embutidas no retrato desta sociedade recém-independente. Sem entrar nestes pormenores, indicamos apenas que os dispositivos formais parecem se acomodar perfeitamente ao conteúdo sedimentado.

O narrador utiliza o humor para criticar a sociedade e, ao mesmo tempo, rever a história chilena, sugerindo pelo riso, uma postura narrativa marcada por uma moralidade normativa. Através do realce do comportamento vulgar da sociedade, o narrador parece legislar sobre as normas de bons hábitos e costumes. Porém, como uma espécie de perversão, Abelardo Manríquez desfaz toda esta moralidade, apontando assim a representação de um mundo debilitado que se direciona para um sentido trágico.

Não intencionamos dizer com isto que se trata aqui de um jogo de forças entre a comicidade e a tragicidade, nem mesmo do narrador com Abelardo Manríquez, mas ao contrário, compreendemos o esquema como a expressão de movimentos contraditórios representativos da arbitrariedade e complexidade da própria matéria narrada que coloca em confronto o ideal amoroso versus o valor pecuniário.

Pela via da intertextualidade assistimos à história do protagonista emoldurada no contexto extemporâneo da Correspondência de Abelardo e Heloísa, provocando desse modo um mecanismo irônico de comparação que ressalta a natureza mesquinha do amor fracassado de Abelardo Manríquez e Inés Arboleda. Como já anunciamos, as transgressões se estabelecem pelo rebaixamento dos motivos e dos personagens da história; o amor imortal é deslocado pela caprichosa ideia fixa; as questões filosóficas que impedem a união do casal de amantes do século XII são reduzidas às motivações econômicas do século dezenove, que apontam a pobreza do nosso protagonista; o abade é diminuído pela figura do calavera e a excepcional Heloísa e substituída pela coquete Inés Arboleda.

As referências à obra epistolar na narrativa de Blest Gana também se encontram nos nomes das personagens; no caso de Abelardo Manríquez, a alusão é bem explícita; já no tocante à Inés Arboleda, o autor usa o artifício do anagrama, Arboleda para Abelardo, admitindo duas possibilidades interpretativas. Uma sugere uma espécie de inversão que simula a comparação de Inés Arboleda com Pierre Abelardo,

${ }^{153}$ FERNANDEZ, Larraín Sergio. Op. Cit. p. 51. 
representação que estaria em contraponto ao espelho da idealização que aproxima mais Abelardo Manríquez de Heloísa e Inés de Pierre Abelardo.

A segunda interpretação, que é complementar à primeira, apontaria para o fato de que a Arboleda (Inês), assim como o Abelardo medieval, rende-se à preservação social em respeito à ordem. No caso do intelectual das epístolas, a relação com Heloísa implicaria o fim de sua carreira como filósofo e professor, enquanto para a moça arrivista e casadoira do romance de Blest Gana, resultaria na perda do status social tão almejado. Mas lembramos que este paralelo sempre é feito à luz da transgressão, já que a comparação de Inés Arboleda com Pierre Abelardo é completamente distorcida dentro da trama.

A leitura que fizemos de El ideal de un Calavera pressupõe o diálogo com a Correspondência de Abelardo e Heloísa, tomando não exatamente a obra em si, mas a leitura que o protagonista realiza dela. Sendo assim, procuramos compreender como o século XIX leu essa Correspondência para determinar quais seriam as influências que encontraríamos na representada leitura de Abelardo Manríquez.

No trilhar deste caminho, observamos os esforços de Blest Gana para construir representações da sociedade chilena. Através destas imagens, descortinamos uma série de perfis de outras personagens que, de alguma maneira, revelam a relação do mundo encenado com a cultura letrada. As leituras imaginativas de Felipe Solama, os livros devotos da biblioteca da casa provinciana e patriarcal del Trébol, os erros ortográficos de Inés Arboleda, a rudimentar escrita das irmãs Candelaria e Martina Basquiñuelas e tantas outras situações registradas nas 36 cartas trocadas pelas personagens durante 0 romance.

Essa quantidade significativa de missivas também nos permite verificar certa preferência da nossa narrativa pelo gênero epistolar, somando assim mais uma vez, a articulação da forma ao conteúdo tão grata ao realismo literário de origem francesa. Expressivas como as interferências trágicas e cômicas, as cartas, tomadas quase que como documentos, cumprem o papel de montar um quadro social convincente da educação da época, chegando em alguns momentos a substituir a voz do narrador.

Com tantas possibilidades de sentido, nos atemos a vislumbrar mais perguntas do que respostas. Sem pretensões de estabelecer verdades sobre o texto, reconhecemos a fragilidade das interpretações que sempre estão sujeitas a modificações e atualizações. Bastando apenas um novo dado para renovar significações a cada nova leitura que realizamos. 
Nesta direção, no penúltimo capítulo do livro, o próprio narrador nos incita a uma nova leitura. Logo após a dramática cena da morte do protagonista, em uma de suas irônicas digressões, ele nos revela que para não desconfigurar a verdade histórica preservou a identidade do jovem fuzilado:

Así murió en la flor de sus años, este joven, á quien ciertas exigencias de un carácter privado y el deseo que hemos tenido de no desfigurar la verdad histórica de los últimos acontecimientos, han despojado de su verdadero nombre en esta narración. Ante este inconveniente no debíamos retroceder nosotros, que deseamos preservar el ser moral, estudiándole al través de las vicisitudes de su vida y en medio de la sociedad que le sirvió de teatro. ${ }^{154}$

A revelação a princípio nos parece um procedimento para conferir à narrativa uma chancela histórica que apontaria para a real existência desta tão singular personagem. Mas também podemos indagar se este procedimento não é mais um embuste do narrador. De alguma maneira, entendemos que este novo quadro pode colocar em xeque toda a construção da personagem Abelardo Manríquez, desarticulando a imagem do calavera que por sua natureza sem regras e normas, pouco se preocuparia em preservar sua identidade. Alterando-se o nome do protagonista, boa parte de nossos argumentos perde facilmente a validade. Num plano geral, o narrador parece querer evitar a desarticulação do romance, pedindo para que não retrocedamos ante a revelação. Deste ponto de vista lançamos a questão: ao preservar o nome do jovem fuzilado, não estaria o romancista pedindo licença para ficcionalizá-lo? Mas isto já é assunto para outra leitura.

${ }^{154}$ BLEST, Gana. Op. Cit. 1908 Tomo II. p.349. 


\section{REFERÊNCIAS BIBLIOGRÁFICAS}

\section{Alberto Blest Gana}

BLEST GANA, Alberto. El ideal de un calavera. Paris: Librería de La Vda. de CH.

Bouret. 1908, Tomo I e II. . El ideal de un Calavera. Santiago: Editorial Andrés Bello, 1999. ."Literatura Chilena. Algunas consideraciones sobre ella" In: El jefe de la familia y otras páginas, Santiago: Zig-Zag, 1956. . La Fascinación, Una Escena Social. La Aritmética en el amor.

Santiago: Zig-Zag, s.d. .Martín Rivas (Novela de costumbres políticos-sociales). Prólogo, Notas

y Cronología Jaime Concha. Caracas: Ayacucho, 1977.

\section{SOBRE BLEST GANA}

CASTRO, Silva Raúl. Historia Crítica de la novela chilena. 1843-1956. Madrid: Ediciones Cultura hispánica, 1960.

CONCHA, Jaime. “Prólogo” In: Martín Rivas. Caracas: Ayacucho, 1977.

CUNNINGHAM, Lucía. Estética Realista y liberalismo en La Aritmética en el amor de Alberto Blest Gana. Texto e ideología en la narrativa chilena. Ed. I\&IL, s/d.

DIAZ ARRIETA, Hernán, (ALONE). Don Alberto Blest Gana. Biografía y crítica. Editorial Nascimento: Santiago: MCMXL, 1940.

.Don Alberto Blest Gana. Santiago:

Nascimento, 1940/ Univ. Diego Portales, 2006.

GOTSCHLICH, Guillermo Reyes. "Grostesco y tragicomedia en El ideal de un calavera de Alberto Blest Gana”. In: Revista Chilena de literatura. N²9 Abril, Ano,1987.

GUNIA, Inke. “Martín Rivas de Alberto Blest Gana”. In: Apropiaciones de realidad en la novela hispanoamericana de los siglos XIX y XX. Frankfurt - Madrid: Ediciones de Iberoamericana, 1994.

HOSIASSON. Laura. “Contradicciones de un Narrador: Martín Rivas” In: Adrián Fanjul; Ana Cecilia Olmos; Mario M. González. (orgs.). Hispanismo 2002: Literatura Hispanoamericana. 1. São Paulo: Ed. Humanitas, 2004, v. III, p. 240-245.

. "Blest Gana, Martín y el Calavera.” In: Revista de Literatura

Chilena, $\mathrm{n}^{\circ} 75$ noviembre de 2009. 
LATCHAM, A Ricardo. Blest Gana y la novela realista. Santiago: Anales de la Universidad de Chile, año CXXVI, núm. 112, $4^{\circ}$ trimestre, 1958.

LARRAIN, Sergio F. (org). Epistolario de Alberto Blest Gana 1856-1903. Santiago: Editora Universitaria, 1991.

LOYOLA, Hernán. “Don Guillermo y Martín Rivas: Visión en paralelo.” In: La novela hispanoamericana: descubrimientos e Invención de América. Valparaíso: Ediciones Universitarias de 1973.

POBLETE Varas, Hernán. Genio y figura de Alberto Blest Gana. Buenos Aires: Editorial Universidad de Buenos Aires, 1968.

ROSEMBERG, Fernando. Martín Rivas de Alberto Blest Gana. Separata de Davar nº 126 Febrero de 1975.

ROJAS, Manuel. Blest Gana, sus mejores páginas. Santiago: Ed. Ercilla, 1961.

SANTOS, Susana. Un tipo digno de imitarse. Buenos Aires: Fronteras literarias en la literatura latinoamericana. Instituto de literatura hispanoamericana, 1996.

\section{CRÍTICA LITERÁRIA/HISTÓRIA/SOCIOLOGIA E OUTROS}

ABELARDO, Pedro. 1079 -1142. Correspondência de Abelardo e Heloisa. Edição e notas ZUMTHOR, Paul. São Paulo: Martins Fontes, 1989.

ADORNO. W Theodor. Notas de Literatura I. Trad. e apresentação Jorge de Almeida. São Paulo: Livraria Duas Cidades/Editora 34, 2008.

ARISTÓTELES. Poética. Trad. Eudoro de Souza. Porto Alegre: Globo, 1966.

AUERBACH, Erich. “Na Mansão de la Mole”. In: Mimesis- A representação da realidade na literatura ocidental. São Paulo: Editora Perspectiva, 1976.

BAKHTIN, Mikhail. Questões de literatura e de estética. A Teoria do romance. São Paulo: Unesp-Hucitec, 1990.

BERLIN, Isaiah. "A apoteose da vontade romântica - A revolta contra o mito de um mundo ideal.” In: Estudos sobre a humanidade- uma antologia de ensaios. São Paulo: Cia das Letras, 2002.

BERSANI, Leo. “O Realismo e o Medo do Desejo.” In: Literatura e Realidade (o que é o realismo). Lisboa: Publicações Dom Quixote, 1984.

BRAIT, Beth. A personagem. São Paulo: Perspectiva, 1972.

BOOTH, Wayne. A retórica da ficção. Lisboa: Arcadia, 1980.

CANDIDO, Antonio. Formação da Literatura Brasileira. São Paulo: Editora Ouro sobre Azul, 2004. 
. "Crítica e Sociologia (Tentativa de esclarecimento)” In: Literatura e

Sociedade. São Paulo: Companhia editora Nacional. 1976

. A personagem de fiç̧ão. São Paulo: Perspectiva, 1972.

BERGSON, Henri. “O Riso” In: Ensaio sobre a significação da comicidade. Trad. Ivone Castilho Benedetti. São Paulo: Martins Fontes, 2000.

COROMINAS, JOAN. Diccionario Crítico Etimológico castellano e hispanoamericano.

Volume I. COROMINAS. (col) José A Pascual. Madrid: Editorial Gredos 3ed, 1991.

COMPAGNON, Antoine. “O Mundo.” In: O Demônio da Teoria - Literatura e Senso Comum. Belo Horizonte: Editora UFMG, 1999

ECO, Humberto. “O uso prático da personagem.” In: Apocalípticos e integrados. São Paulo: . Perspectiva, 1970.

ENCINA, Francisco. Historia do Chile. Desde la prehistoria hasta 1891. Vols 15-16. Santiago: Nascimento, 1951.

. La literatura histórica chilena. Santiago: Universitaria, 1977.

DIXON, Paul. O Chocalho de Brás Cubas- Uma leitura de Memórias Póstumas. São Paulo: Edusp/ Nanquin, 2009.

ESTÊVÃO, José Carlos. A Ética de Abelardo e o Indivíduo. Dissertação apresentada à Pontifícia Católica de São Paulo PUC-SP. São Paulo, 1990.

FOUCAULT. Michel. A ordem do discurso. Trad. Fraga de Almeida Sampaio. São Paulo: Ed. Edições Loyola, 1996.

FRYE, Northrop. Anatomia da crítica. Trad. Péricles da Silva Ramos. São Paulo: Cultrix, 1973.

FORESTI, Carlos. LOFQUIST, Eva. FORESTI, Alvaro. La Narrativa Chilena desde la Independencia hasta la guerra del Pacífico. Tomo I -1810-1859. Santiago: Editora Andrés Bello, 1988.

GENETTE, Gérard. Discurso da narrativa. Lisboa: s.d.,

GONZALEZ STEPHAN, Beatriz. La historiografía literaria del liberalismo hispanoamericano del siglo XIX. Habana: Casa de las Américas.1987.

HAMBURGUER, Käte. A lógica da criação literária. Trad. Margot Malnic. São Paulo: Perspectiva, 1975.

HEGEL, Georg Ludwig Friedrich. Curso de estética: o sistema das artes. São Paulo: Martins Fontes, 1997.

HOBSBAWM, Eric. “Introdução: A invenção das Tradições”. In: HOBSBAWM , Eric \& RANGER, Terence (orgs.). A Invenção das Tradições. Rio de Janeiro: Paz e Terra, 1997. 
INGENIEROS, José. Tratado del Amor. Buenos Aires: Editorial Losada S. A, 1970.

JAMESON, Frederic. "Realismo y deseo: Balzac y el problema del sujeto”. In. Documentos de cultura. Documentos de barbarie. Madrid: Visor, 1989.

LAERA, Alejandra. El tiempo vacío de la ficción. Buenos Aires: FCE, 2003.

LARRA. José, Mariano. “Los Calaveras.” In: Artículos. Edición de Enrique Rubio. Madrid: CÁtedra, 1987.

LUKÁCS, Georg. Teoria do Romance- um ensaio histórico- filosófico sobre as formas da grande épica. Trad. Posfácio e notas José Mariani de Macedo. São Paulo: Livraria Duas Cidades /Ed.34, 2000. . La Novela Historica. México: Ediciones Era, 1966.

LIMA, Luiz Costa. “Os atos de fingir ou o que é fictício no texto ficcional.” In: Teoria da Literatura em suas fontes. Rio de Janeiro: Alves, 1975.

ORTEGA, José, y Gasset. “Notas sobre o amor cortês”. In: Estudos sobre o amor. Trad. E Prólogo Luis Washington Vita. Rio de Janeiro: Livro Ibero- Americano LTDA. 1960

PERRONE-MOISÉS. Leyla. Vira e Mexe Nacionalismo - Paradoxos do Nacionalismo Literário. São Paulo: Cia das Letras, 2007.

RAMÓN, Armando. Santiago de Chile (1541-1991) Historia de una sociedad urbana. Madrid: Editora Mapfre, 1992.

RAMOS, Julio. Desencuentros de la modernidad en América Latina- Literatura y política en el siglo XIX. México: Fondo de Cultura Económica, 1989.

RAYMOND. Williams. El Campo y la ciudad. Buenos Aires: Paidós, 2001.

RILEY, Edwar, C. “Cervantes una Cuestión de Género.” In.: El Quijote de Cervantes. Madrid: Taurus ediciones, 1980.

ROUGEMONT, Dennis. O amor e o Ocidente. Lisboa: Moraes Editores, 1968.

ROSENFELD, Anatol. “A teoria dos gêneros.” In: Teatro épico. São Paulo: Perspectiva, 1986. . Estrutura e problemas da obra literária. São Paulo: Perspectiva, 1976. . "Reflexões sobre o romance moderno" In: Texto/Contexto. São Paulo: Perspectiva, 1969.

SAER, Juan José. El Concepto de Ficción. Buenos Aires: Planta, 1980.

SAGREDO, R. y GAZMURI, C. (dir.) Historia de la vida privada en Chile. Santiago: Aguilar/ Taurus, 2005.

SANTIAGO, Silviano. "Eça, autor de Madame Bovary”. In: Uma literatura nos trópicos, São Paulo: Perspectiva, 1978.

SARMIENTO, F. Domingo. Chile - Descripciones- Viajes- Costumbres. Buenos Aires: Editora Universitaria., 1961.

SCHWARZ, Roberto. Ao vencedor as Batatas. (Formas literárias e processo social nos inícios do romance brasileiro). São Paulo: editora 34, 2000. 
."Moderno, nacional, e negativo.” In: Que horas são? São Paulo:

Companhia das Letras, 1989.

SECO, Carlos Serrano. Biblioteca de Autores Españoles-obra de Don Ramon de Mesonero Romanos. Tomo I e II. Madrid: Real Academia Española, 1967.

SIMMEL, Georg. “Psicologia do Coquetismo.” In: Filosofia do amor. Trad. Luís Eduardo de Lima Brandão. São Paulo: Martin Fontes, 1993.

SOMMER. Doris. Ficções de Fundação. Belo Horizonte: Editora UFMG, 2004.

SUBERCASEAUX. Bernardo. Historia de las Ideas y de la Cultura en Chile. "Tomo I:

Sociedad y cultura liberal el siglo XIX: J. V. Lastarria”. Santiago: Editorial Universitaria, 1997.

Editorial Andrés Bello, 2010.

Historia del libro en Chile (Alma y Cuerpo). Santiago de Chile:

STUVEN, Ana María. La seducción de un orden. Santiago: Ediciones Universidad Católica de Chile, 2000.

VAINFAS, Ronaldo. Casamento, amor e desejo no ocidente cristão. São Paulo: Editora Ática, 1992.

VERNANT, Jean Pierre. Mito e tragédia na Grécia Antiga. São Paulo. Livraria duas cidades, 1977.

VILELA. PE. Orlando. O drama de Heloísa- Abelardo. Belo Horizonte: Editora Itatiaia Limitada. 1986.

UREÑA, Pedro Henrique. Las Corrientes Literarias en la América Hispánica. México: Fondo de Cultura Económica, 1949.

WASSERMAN. Fabio. "Las prendas geniales de nuestra sociedad: Representaciones del pasado e identidad nacional en el discurso de las elites político- letradas chilenas (18401860).” In: Revista Ibero Americana, año III (2003) n9.

WILLIAMS, Raymond. El Campo y la ciudad. (1973) Barcelona: Paidós, 2001.

WHITE, Hayden. Trópicos do discurso. São Paulo: Edusp, 1994.

ZAMUDIO, José. La novela histórica en Chile. Santiago: Flor nacional, 1949.

ZANETTI, Susana. La dorada garra de la lectura- lectoras y lectores de novela en América latina. Rosario: Beatriz Viterbo, 2002.

ZUBIAURRE, María Teresa. El espacio en la novela realista. (Paisajes, miniaturas, Perspectivas). México: Fondo de Cultura Económica, 2000. 